\title{
DATA QUALIFICATION SUMMARY FOR 1985 L-AREA AC FLOW TESTS (U)
}

by T. B. Edwards, et al.

Westinghouse Savannah River Company

Savannah River Site

Aiken, South Carolina 29808

D. A. Eghbali

M. L. Liebmann

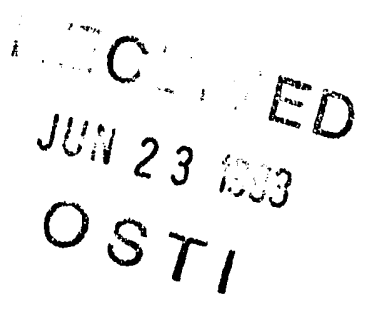

E. P. Shine

This paper was prepared in connection with work done under Contract No. DE-AC09-89SR18035 with the U. S. Department of Energy. By acceptance of this paper, the publisher and/or recipient acknowledges the U. S. Government's right to retain a nonexclusive, royalty-free license in and to any copyright covering this paper, along with the right to reproduce and to authorize others to reproduce all or part of the copyrighted paper.

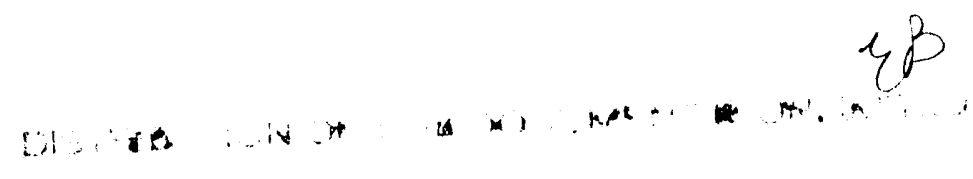


NRTSC

Nuclear Reactor Technology

And Scientific Computations
NRTSC

Technology

On Time

On Target

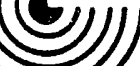

WSRC-TR-92-134

Task 91-033-1

\title{
Data Qualification Summary for 1985 L-Area AC Flow Tests (U)
}

by

\author{
T. B. Edwards \\ D. A Eghbali
}

M. L. Liebmann*

E. P. Shine

Issued: $\quad$ March, 1992

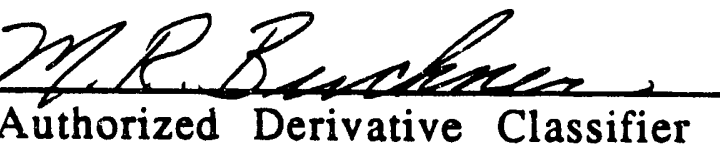

* M.L. Liebmann, a member of the task team, made significant contributions to this study, but left WSRC before the preparation of this document.

\section{SRL}

Savanis. River Laboratory, Aiken, SC 29802

Westinghouse Savannah River Company

Prepared by the U. S. Department of Energy under Contract DE-AC09-88SR18035 
Document :

Title:

Task Number:
W SR C - TR - 92 - 134

Data Qualification Summary

for 1985 L-Area AC Flow Tests (U)

Approvals

$91 \cdot 033 \cdot 1$

$\frac{0.6 . E \text { Calends }}{\text { T. B. Edwards, Author }} \frac{3-10.92}{\text { Date }}$

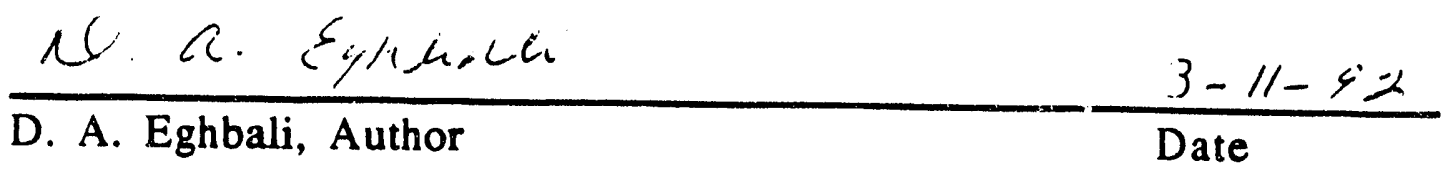
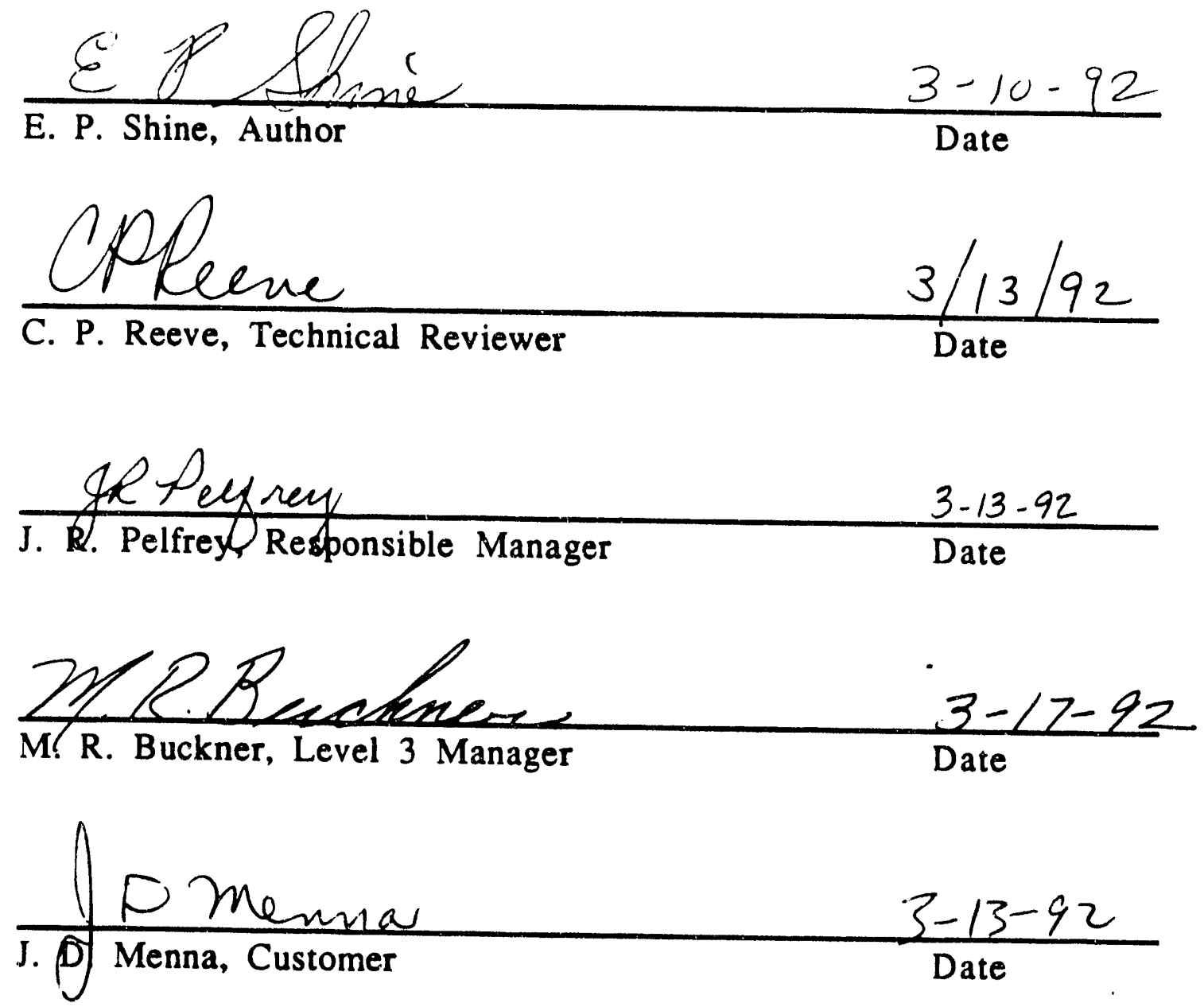


\section{TABLE OF CONTENTS}

Section

Page

1.0 Executive Summary.................................................

2.0 Introduction .............................................................

3.0 Overview of the 1985 L-Area AC Flow Tests ... 1

4.0 Data Acquisition and Instrumentation ................ 2

5.0 Description of Important Data ............................... 5

6.0 Measurement Uncertainties .................................... 7

7.0 Description of Data Keying and Verification ..... 9

8.0 Raw Data Adjustments and Derived Parameters 9

9.0 Overview of the Data Qualification Process ....... 11

10.0 Explanation of the Data Qualification Methods 14

11.0 Data Integrity Review .................................................. 17

12.0 Conclusions ................................................................ 22

13.0 References ....................................................................... 23

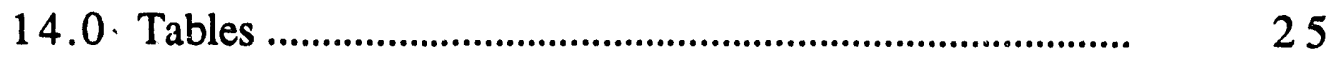


Listing of Tables

Table

Page

Table 11985 L-Area AC Flow Test

Configurations .................................................. 25

Table 2 Plenum Pressure Measurements ............... 26

Table 3 ScaniValve Positions and Loop Pressure

Tap Locations .................................................... 27

Table 4 Test Sequence and Ultrasonic

Flowmeter Placement ................................... 28

Table 5 ACDATA3 ……….......................................... 29

Table $6 \quad$ PLENUM2 for Test A ....................................... 32

Table $7 \quad$ PLENUM2 for Test B ....................................... 35

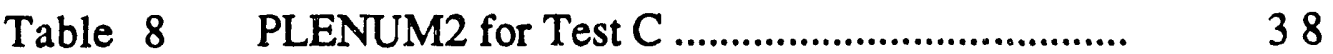

Table 9 PLENUM2 for Test D ...................................... 41

Table $10 \quad$ PLENUM2 for Test E ......................................... 44

Table 11 PLENUM2 for Test F ..................................... 47

Table 12 PLENUM2 for Test G ..................................... 50

Table 13 PLENUM2 for Test $\mathrm{H}$......................................... 53

Table 14 PLENUM2 for Test I ..................................... 56

Table $15 \quad$ PLENUM2 for Test J ....................................... 59

Table 16 PLENUM2 for Test K ....................................... 62

Table 17 Test A: Results of Data Qualification of 1985 L-Area AC Flow Tests ......................... 65

Table 18 Test B: Results of Data Qualification of 1985 L-Area AC Flow Tests .......................... $\quad 70$

Table 19 Test C: Results of Data Qualification of 1985 L-Area AC Flow Tests .......................... 75

Table 20 Test D: Results of Data Qualification of 1985 L-Area AC Flow Tests ......................... 80

Table 21 Test E: Results of Data Qualification of 1985 L-Area AC Flow Tests

Table 22 Test F: Results of Data Qualification of 1985 L-Area AC Flow Tests ......................... 90

Table 23 Test G: Results of Data Qualification of 1985 L-Area AC Flow Tests .......................... 95

Table 24 Test H: Results of Data Qualification of 1985 L-Area AC Flow Tests ......................... 100

Table 25 Test I: Results of Data Qualification of 1985 L-Area AC Flow Tests 


\section{Listing of Tables (continued)}

Table

Page

Table 26 Test J: Results of Data Qualification of 1985 L-Area AC Flow Tests

110

Table 27 Test K: Results of Data Qualification of 1985 L-Area AC Flow Tests.... 


\subsection{Executive Summary}

An extensive study of the data from the 1985 L-Area AC Flow Tests was recently completed [1]. The purpose of that study was to provide corroborating technical information as to the quality, fitness for use, of these experimental data. This report provides highlights from that study: an overview of the tests and their data, a description of the instrumentation used, an explanation of the data qualification methods employed to review the data, and the important conclusions reached from the study.

\section{$2.0 \quad$ Introduction}

This report summarizes the results of the recently completed, formal, technical review of the data from the 1985 L-Area AC Flow Tests as detailed in document SCS-CMAS-910045 [1]. The purpose of that review was to provide corroborating technical information as to the quality (fitness for use) of these experimental data. Reference [1] required three volumes to fully document the results of that Data Qualification process. This report has been prepared to provide the important conclusions from that process in a manageable and understandable format. Consult reference [1] if any additional information or cetail is needed.

\subsection{Overview of the Tests}

The 1985 L-Area AC Flow Tests were conducted to provide an extended data base for upgrading the reactor system models employed in predicting normal process water flows [2]. To span a reasonable range of system flows and temperatures, these tests consisted of 11 different steady-state and simulated-LOCA configurations, including:

1. normal operation,

2. operation with septifoil system isolated,

3. operation with one (of two) heat exchangers isolated in each loop,

4. operation with one pump off and the loop in backflow (simulates LOCA), 
5. operation with three pumps off and the rotovalves isolated in each of the loops.

The tests were run at "cold" ( 22 degrees Celsius) and "warm" ( 60 degrees Celsius) to evaluate the effects of temperature on flow. The test conditions and naming conventions are provided in Table 1 . For all of the tests, the reactor moderator tank was at overflow conditions with no helium blanket gas present and vented to the process room through the vacuum breakers and normal blanket gas piping.

The AC Flow tests data were originally reduced and released in [3].

\subsection{Data Acquisition and Instrumentation}

The instrumentation and data acquisition systems used during the 1985 L-Area AC Flow Tests are fully described in reference [1]. The original measurements as recorded on paper tapes and data sheets, the special procedure and authorization for the tests, photos, figures and other pertinent information were all reviewed during the Data Qualification process to provide a description of how the data from the tests were acquired.

During the test suns, data were acquired at selected intervals by three Acurex Dataloggers. Two of these (Model Ten/10) were located at the reactor room station (the $0^{\prime}$ elevation) and the third one (Model Ten/30) was located on the heat exchanger level (the $-20^{\prime}$ elevation data station). For many of the critical system pressures, impulse lines were routed to a multi-position scanning valve ("Scanivalve") that was connected to a pressure gauge ("Heise Gauge") and one of these data loggers.

The outputs from the dataloggers, which were provided on paper tapes, were the primary source of raw data for the tests. For each of the 11 tests, the first datalogger, located at the process room level, provided a paper tape with plenum pressures and locations (44 point averaging), as shown in Table 2. The paper tape from the second datalogger, located on the heat exchanger level provided the loop locations and pressures (15 point averaging), as shown in Table 3 . The printout frequency for both dataloggers was approximately 1 per minute. Thus, each plenum pressure location, designated by an on-line computer (OLC) number, 
was sampled about every 48 minutes, each pump suction location every 7 minutes and all other loop locations every 21 minutes.

Additional measurements were recorded manually using seven data sheets, which were numbered 1 through 7 . Data Sheet \#1 was used to record pump suction temperature every 15 minutes, by which the approach to steady-state process water temperature was observed and maintained. Data Sheet \#2 was used to record pump differential pressure, plenum inlet temperature, pump suction temperature, and plenum centerline pressure every 30 minutes. Data Sheet \#3 was used to record barometric pressure at the heat exchanger bay data station every hour and flow rate using ultrasonic flowmeters every 30 minutes. Data Sheet \#4 was used to record pressure at tank bottom centerline (Automatic Incident Action (AIA) positions in Gang 1), low pressure header, and three Mark 60B taps at the $-40^{\prime}$ elevation data station. The other data sheets (\#5-\#7), which were used to record and monitor information including Caterpillar diesel engine performance, process water temperature, reactor level, and cooling water temperature, were not involved in the Data Qualification process.

A more detailed review of the instrumentation is now provided by measurement type.

\section{Loop Temperatures:}

Process water temperatures were measured using existing plant Resistance Temperature Devices (RTD's) at pump suction and plenum inlet for all six loops.

\section{Loop Pressures:}

Measurements of pressure at pump suction and discharge, and heat exchanger inlet and discharge were performed using the datalogger Ten/30 located at the -20 ' elevation along with two 48-port Scanivalves and two Heise digital pressure gauges. The 0 . 30 psia Heise gauge was used at pump suction. The other loop pressures used the $0-300$ psig Heise gauge. The pump differential pressures were recorded on the data sheets.

Loop Flows:

A number of devices were used to provide measurements of loop flows during these tests. 
1) A Laser Doppler Anenometer (LDA) was used at system or loop 1 to measure the loop flow. Data from the LDA, which were collected on floppy disks, were not considered in the DQ study.

2) Pitot tubes were inserted (2.5" inside pipe) at the heat exchanger inlet for all six loops. These tubes were fabricated at Savannah River Laboratory (SRL) and were not calibrated prior to use. The differential pressure readings provided by the pitot tubes, which were collected using the datalogger at the $-20^{\prime}$ elevation data station, were not considered in the DQ study.

3) Three Controlotron System 480 Wide-Beam Clamp-On Ultrasonic Transit Time (UTT) flowmeters were used to measure the pump flow during the AC tests. One of UTTs was mounted on system or loop 1 while the other two UTTs were placed on various systems (see Table 4).

The two System 484 Flow Display Computers (A\&B), which were used to convert the transducers' signals to flow in kgpm, were stored in the Heat Transfer Laboratory (HTL) after the testing was completed.

\section{Plenum Pressures:}

Ninety modified assembly plenum shield plugs were fabricated to replace the normal plenum shield plugs for the positions (OLC locations) of interest. Each plug employed a feed-through pressure tube which dipped into the coolant. Pressure tubing connected the outside end of the feed-through to two 48-port Scanivalves. The impulse tubing from half of the plugs (Series "A" plugs on the paper tape) was connected to one 48-port Scanivalve while the tubing from the other half (Series "B" plugs on the paper tape) was connected to the other automatically by synchronized steppers. The output tubing from each Scanivalve was connected to an electric Heise digital pressure gauge. Signals from the Heise gauges were recorded by one of the Ten/10 dataloggers located in the reactor room station. The $0-200$ psig Heise gauge was used for the plenum pressure measurements. 
Assembly Flows:

Assembly flows were measured in up to six fuel assemblies at selected buckle-zone positions using special high-flow venturimeters installed above the assemblies in the sleeve housing. Each venturimeter was complete with a housing shield plug through which two nylon pressure tubes passed. The venturi assemblies replaced the normal reactor shield plugs. These venturimeters were assembled and calibrated in the HTL prior to use. These data were not considered during the DQ study.

Septifoil Flows:

A Controlotron ultrasonic (UTT) flowmeter was installed on the far-side septifoil intersection to measure the septifoil flow. These data were not considered in the DQ study.

Monitor Pin Differential Pressures:

All monitor pin differential pressures were measured using the existing plant instrumentation, but these data were not considered in the DQ study.

Emergency Coolant System (ECS) Injection Point Pressures:

ECS injection point pressure was measured using the $0-300$ psig

Heise gauge as described above for the loop pressures.

\section{Plenum Centerline Pressures:}

The plenum centerline pressure was measured using existing instrumentation, System "A" and "B" on the control computer.

Moderator Tank Bottom Pressures:

The 0-50 psig Heise gauge was used to measure tank bottom pressures at five locations: GANG 1 AIA, Low Pressure Header, and three Mark 60B OLC locations.

\subsection{Description of Important Data}

A significant amount of data was collected during the 1985 L-Area AC Flow Tests, this section describes the data that were considered for qualification. 


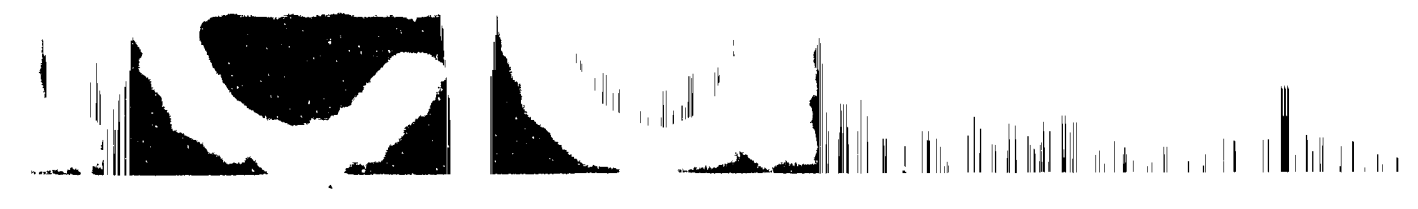

WSRC-TR-92-134

Task 91-033-1

DQ Summary for 1985 L-Area AC Flow Tests

March 10, 1992

Revision 0

Page 6 of 119

\section{Loop Water Temperatures:}

Three temperature data streams were recorded for each test:

pump suction water temperature using Data Sheets \#1 and \#2 and plenum inlet water temperature at two locations (usually) in each loop. These data streams were investigated in order to determine an appropriate process water temperature which was used in the adjustment of pressures and calculation of flows.

\section{Barometric Pressure:}

The barometric pressure was used in the conversion from gauge to absolute pressure. An atmospheric pressure of 1013.15 millibars was used as the conversion for $14.696 \mathrm{psia}$. The maximum expected variation of barometric pressure was considered to have negligible effect on these pressure conversions.

\section{Loop Pressures:}

These pressures outlined in Table 3 are a critical part of the data that was reviewed. The pump differential pressures, recorded on Data Sheet \#2, were not reviewed since few of these measurements were taken.

\section{Plenum Pressures:}

Detailed in Table 2, these data streams were reviewed as part of the DQ study.

\section{Loop Flows:}

Of the data on loop flows, only the three UTT flowmeters were reviewed as part of the $D Q$ process.

\section{Plenum Centerline Pressures:}

The plenum centerline pressure measurements were recorded in two places: the Bailey System "B" (central control room recorder) using Data Sheet \#2 and the Heise Gauge System "A" using a datalogger.

\section{Tank Bottom Pressures:}

The low pressure header pressure is composed of six common pressure taps located at the tank bottom in the gas port positions. Therefore, these pressures should provide a good comparison to the Mark 60B measurements. During the asymmetric tests, a 
larger difference between the average and individual measurements was expected because the Mark 60B locations were clustered in the adjacent loop 1 and 6 sectors.

The AIA GANG 1 pressure measurements were derived from pressure taps near the tank center that were part of the absolute and differential pressure sources for tank level indication to the AIA system. No additional information was found on the specific instrumentation. The 0-50 psig Heise gauge was used for these measurements.

A secondary experimental measurement from the 1985 tests that was provided in reference [3] was the manometer temperature. This temperature could not be found on any data sheet or in any logbook. Test personnel could wot recall where the temperature originated. It is used to adjust the static head for the instrument pressure lines and therefore, the temperature should be approximately process room temperature. Values of 25 degrees and 40.5 degrees Celsius were used for all of the cold and warm tests, respectively.

Variations in manometer temperature were determined to have little effect on the pressure arijustments as demonstrated in [4].

\subsection{Measurement Uncertainty}

The uncertainties of the measurements from the instruments used in the L-Area 1985 AC Flow Tests were difficult to determine. An attempt was made as part of the DQ study to estimate the potential bias or systematic error for the measurements.

The following table presents the Heise digital pressure gauges that were used during the 1985 L-Area AC Flow Tests: 
WSRC-TR-92-134

March 10, 1992

Task 91-033-1

DQ Summary for 1985 L-Area AC Flow Tests

Revision 0

Page 8 of 119

\begin{tabular}{|lllll|}
\hline Type & Model & Serial \# & Range & Unit \\
& & & & \\
Heise & $710 \mathrm{~A}$ & S7-18478 & $0-30$ & psia \\
Heise & $710 \mathrm{~A}$ & $\mathrm{S7}-18457$ & $0-50$ & psig \\
Heise & $710 \mathrm{~A}$ & $\mathrm{S7}-18456$ & $0-100$ & psig \\
Heise & $710 \mathrm{~A}$ & $\mathrm{S7}-18455$ & $0-200$ & psig \\
Heise & $710 \mathrm{~A}$ & $\mathrm{S7}-18454$ & $0-300$ & psig \\
\hline
\end{tabular}

Calibration sheets [5] and manutacturer's information [6] were available to assist in the following uncertainty analysis for bias for the pressure measurements from the Heise gauges:

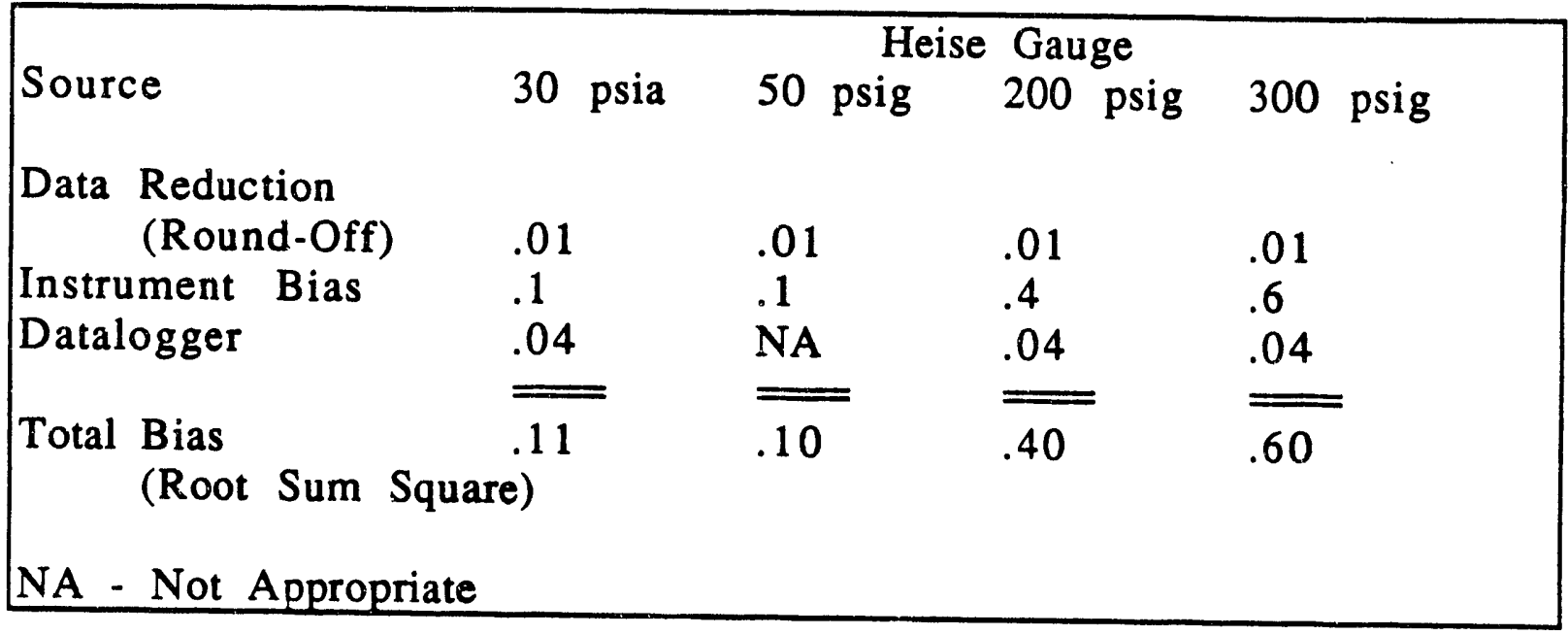

The estimates of instrument bias used were at least twice those quoted by the Heise gauge manufacturer [6]. Sources of variation such as linearity, hysteresis, and temperature were considered insignificant [6]. The bias from the datalogger was estimated from periodic checks made against the Heise gauge output during the tests that were recorded in [7 \& 8].

The investigation into RTDs used for taking water temperatures provided calibration and uncertainty information on instruments similar to those used in the 1985 tests [9]. No calibration information traceable to National Institute of Standards and Technology (NIST) could be found for the instruments used in this test. A bias estimate for these instruments could not be determined. 
The uncertainty provided by the manufacturer of the Controlotron Ultrasonic Transit Time Flowmeters was used to estimate the bias at $3 \%$ [10]. The UTTs were calibrated by the manufacturer.

The plenum centerline pressures were recorded with existing System "A" and System "B" instrumentation. Reference [11] estimated a total System "A" uncertainty of $\pm 1.1 \%$ of 150 psig span or \pm 1.65 psig and a System "B" uncertainty of $\pm 0.9 \%$ of 100 psig span or \pm 0.9 psig. These uncertainties were considered as conservative limits on the bias for these measurements.

\subsection{Description of Data Keying and Verification}

The data manipulation for the DQ process began with the test data in their original form, on paper tapes and data sheets. These data were manually keyed into the MicroSoft EXCEL software package on an Apple Macintosh personal computer. Data from twenty-two paper tapes and from data sheets 1 through 4 for all eleven tests were keyed into EXCEL. Eleven of the paper tapes recorded the loop pressures and eleven recorded the plenum pressures.

Since reference [3] provided many of the measurement averages computed from the 1985 test data, this document was used as an independent verification of the EXCEL data. Other methods used to verify the correctness of the EXCEL data were documented in reference [1].

\subsection{Raw Data Adjustments and Derived Parameters}

A formal review of adjustments to and some parameters derived from the raw data was included within the scope of the DQ study. This was done for two reasons. First, the adjusted and derived values were otten used to facilitate the DQ process. Secondly, these values have many applications and are, therefore, of interest in their own right.

The origin of these adjustments and derived parameters can be traced back to two programs, PLENUM and ACDATA2, which were presented in [3]. PLENUM was used to convert the raw pressure measurements from 
inside the universal sleeve housing (USH) and to calculate the assembly flow from the pressure. ACDATA2 provided a conversion of the raw pressure measurements from around the loops and adjusts them to the actual tap locations, accounting for the hydrostatic pressure difference between the taps and gauges. ACDATA2 also determined a loop flow from the corrected pump differential pressure.

Incorporated into the $D Q$ task was the technical review of these two programs [4, 12,\& 13]. Several changes resulted from this technical review and from corrections made by the author (noted as "LDK corrections") of reference [3] subsequent to its release. These changes are shown below:

ACDATA3 corrections to original ACDATA2 program

- Add density correlation for input process and manometer temperatures,

LDK Corrections

- Change tank bottom from $-20^{\prime}$ to $-19.25^{\prime}$ elevation,

- Add elevation difference between pump suction and discharge pressure taps to pump head calculation.

PLENUM2 corrections to original PLENUM program

- Change density correlation,

- Change viscosity correlation,

- Adjust measured plenum pressure to account for tap-togauge elevation,

- $\quad$ Adjust head in USH for actual weir elevation below $0^{\prime}$ elevation,

LDK Correction

- Change sign for plenum-to-tank elevation adjustment in USH head calculation. 
As indicated in the above tables, the revised programs were renamed ACDATA3 and PLENUM2 during the DQ study. This was to distinguish them from the original versions. They were applied to the 1985 L-Area AC Flow Tests data. See references $[1,4,12, \& 13]$ for more details on the evaluation of the impact of these program changes on the resulting values.

ACDATA3 adjusted the measured loop and tank bottom pressures from the transducer locations to the actual pressure tap locations, accounting for hydrostatic pressures in the lines between the taps and gauges. ACDATA3 also accounted for density changes due to process system and process room (for pressure tap to transducer lines) temperature. The program calculated the loop forward flows by converting the adjusted flow using the cubic pump curve from reference [14]. Table 5 provides the results for ACDATA3 calculations.

PLENUM2 provided the conversion of the raw (measured) pressures inside the USH to corrected pressures outside the USH, at the top of the plenum. The relationship between flow and pressure loss from the outside to inside of the USH was based on adjusted A-tank test measurements. The program also accounted for viscosity and density changes with temperature to encompass the warm and cold tests. PLENUM2 calculated the assembly flows using the Newton-Raphson technique, first determining the head inside the USH from the plenum pressure measurements and then iterating to find the corresponding flow. Then using a flow equation based on head between the plenum and tank bottom [15] and $\mathrm{K}$-factors derived from the fuel assembly hydraulic manuals, the head and pressure outsije the USH were calculated. Tables 6 through 16 provide the results for these PLENUM2 calculations.

\subsection{Overview of the Data Qualification Process}

Data Qualification is the process of verifying that the measurement data from an experiment represent the system under the experimental conditions.

An important aspect of the 1985 L-Area AC Flow Tests, in formulating the methods for the DQ process, was that most of the test data were to 
be recorded after the processing reached steady-state conditions for each test configuration. All data streams were recorded during holdpoint conditions with two exceptions - the data streams for water temperature and barometric pressure. As stated earlier, water temperature was monitored during the testing to identify and maintain the steady-state condition for each test. Operator intervention maintained the water temperature within an acceptable range for each test. Steady-state processing offered special opportunities for checking the quality of the resulting data streams. These opportunities are investigated below.

The data qualification process consisted of methods for investigating:

1. Range

This was a reasonableness check to make sure that the data from an instrument were within the expected operational range for that instrument.

2. Stability

Each data stream should have shown evidence of a stable process and instrumentation as a result of the testing being conducted at steady-state conditions.

3. Consistency

The behavior of the measurements in relation to the sequence of events of the testing were reviewed for consistency.

4. Precision

Precision is the agreement of the data in a data stream among themselves. It is the repeatability of the measurements in a single data stream. An estimate of the precision is provided by the standard deviation of the data stream. The standard deviations of data streams over the 11 tests were investigated for consistent behavior

\section{Accuracy}

The accuracy of the data from an instrument is the closeness of the data to the true value of the system under the conditions being tested. Accuracy was investigated by studying data streams that were expected to behave similarly. 
For these techniques, instrument readings, computational models, associated uncertainties, and assumptions regarding measurement relationships which depend on engineering and other expert judgment are required. The DQ methods, which are more fully developed below, were applied to each measurement data set (the data stream for a single instrument) for each test. Engineering and experimental insight provided much of the information necessary to identify behavior that should be demonstrated in the data. The statistical aspects of these investigations led to descriptions of the data stream which were then reviewed for practical importance from engineering and experimental aspects. The final decision on the quality of the data was a joint decision based upon the best efforts of the DQ team.

Each of these data streams were assigned a label (QUALIFIED, CONDITIONALLY QUALIFIED, or FAILED) as a result of the investigation. If the data set was not FAILED, a mean and standard deviation were provided as representative of this process measurement. Other labelling schemes have been used in previous DQ efforts [16]. The labels used in this study are defined below.

The label "QUALIFIED" was to be assigned to the data if the above areas of investigation revealed no problems and the necessary uncertainties could be determined and evaluated.

If uncertainties were incomplete or not available, if the traceability of instrument calibrations could not be verified, or if the accuracy of data streams could not be confirmed, then the label CONIITIONALLY QUALIFIED was assigned to the measurements.

The FAILED label was to be used if an instrument failure was detected, or no useful information was retrievable, or if there were significant problems with the data.

The CONDITIONALLY QUALIFIED label should not be confused with the CONDITIONAL label used by Idaho National Engineering Laboratory (INEL) on an interim basis during their qualification of the 1989 L-Area tests [16]. 


\subsection{Explanation of the Data Qualification Methods}

In the sections below, each of the areas of investigation mentioned earlier is discussed in more detail. The methods used for the investigation are also provided.

\section{Measurements within Range}

The range check was used to verify that data streams were within feasible limits and to identify out-of-range conditions for each instrument. The out-of-range check for each of the instruments utilized the manufacturer's stated operating range or the calibrated range for the instrument. The range check entailed a manual review of time charts for each of the data streams. All measurements in a data stream were verified to be within this operating range as part of this check. The range check was passed if no outliers were detected. If some out-of-range measurements were detected, then this condition was investigated to determine if it was process or instrument related. If the outlier was due to the data collection system, for example a transcription error, the outlying measurement was deleted or adjusted. The impact of any remaining outliers was examined and reported.

\section{Process and Instrument Stability}

Process and instrument stability should be demonstrated in the measurement data acquired under steady-state conditions. Under these conditions, an instrument's data stream should reveal no trend over time, a constant mean level, and constant variation. Identification of outliers and dropouts was also a part of this examination.

Stability of a data stream was reviewed by examining plots of the data streams versus time. The number of observations for some of these data sets was very small, but a significant amount of time usually elapsed between observations providing snap shots over a relatively long period of time.

Charts were based on a single data stream or pooled information for several streams if possible. If no trend or pattern was 
identified, the stability test was passed. An explanation was sought for any trend or pattern found in the data. For example, temperature data streams were not expected to be stable. If a trend existed, it was determined whether the trend was sufficiently large, based on engineering principles, to impact results.

\section{Measurement Consistency}

Consistency checks are an investigation into the relationships among test conditions and data streams. The impact of various test conditions on the resulting measurements were examined. Certain behaviors were predictable over the sequence of events for the tests and these should be demonstrated in the data, usually through the arithmetic averages of the measurement data streams.

Plots of the measurement averages for the various groups of instruments over the eleven tests were developed. Some tables were prepared comparing the results of paired tests experiments whose test conditions differed only in temperature. Models were also developed to estimate the effects of the test conditions on the measurement data streams. These models provided an empirical consistency check. For each of these approaches, the results were reviewed to determine if the results demonstrated behavior that was consistent with engineering or other scientific principles.

The residuals (the differences between the actual and predicted values) were studied in order to find data streams that exhibit atypical behavior. If the residual could be explained there was no problem. If not, then the consistency check was not passed for data stream.

\section{Measurement Precision}

As an experiment is planned, the question of adequate instrument precision or repeatability is answered by uncertainty analyses, MT\&E information for this instrument class, and/or by expert opinion. 
A measure of repeatability of a data stream is provided by the standard deviation of the measurements under stable conditions. This variability may be examined for consistency across various test conditions such as temperatures, loops, etc. The method used to examine instrument precision began with the calculation of the standard deviation for each data stream. These statistics were manually reviewed for consistency and compared to the expected results from the uncertainty analyses.

\section{Measurement Accuracy}

The determination of the accuracy of a data stream is an important part of the evaluation of any experimental result. One of the best accuracy checks is a test of the instrument against nature under process conditions, such as an in situ calibration. Instrument redundancy is valuable when each instrument cannot be directly tested against nature under experimental conditions to judge its accuracy or, the reverse, its degree of bias. Instruments may fall into different redundancy groups; no redundancy, redundancy of similar instruments, and redundancy based on different first principles. Detection of many of the causes that affect instrument bias can be shown to be related to this structure. If an instrument has no redundancy, then any cause may lead to an undetected bias. If two similar instruments are redundant, then only causes that systematically affect both remain undetected. An example would be a faulty calibration procedure applied to all. instruments of the same type or an impurity that interferes with an assay. If two instruments are redundant and behave according to different first principles, then the class of possibly undetected biases is shrunk to those that are systematic across instrument classes. Two assays methods based on different first principles may both suffer the same bias if both are calibrated with the same incorrectly labeled standard. The result of this grouping offers a rational for increasing confidence that no bias is present, when each instrument cannot be directly tested against nature.

Some redundancies were available for the 1985 results. The qualified data from AC4 Modified (Hold-point 19) in the $1989 \mathrm{~L}$ - 
Reactor hydraulic tests was used as an historical redundancy [17]. This test which was qualified by INEL was conducted under the same conditions as Test B of 1985 L-Reactor tests. Therefore the loop measured parameters for these tests were compared directly for redundancy purpose. The plenum pressure distributions of these tests could not be directly compared due to the impact that different fuel charges have on plenum pressure distributions. The fuel charges for 1989 L-Reactor tests were Mark 22 while the fuel charges for 1985 L-Reactor tests were a combinations of Marks $16,31 \mathrm{~B}$, and $60 \mathrm{~B}$. Other redundancies available for the 1985 results are discussed below.

The comparison of redundant data streams involved the investigation of the difference(s) of the means of the data streams. The significance of their difference(s) was judged from two perspectives, engineering importance and statistical uncertainty. Situations where the difference was sufficiently large from the engineering perspective to warrant concern and/or the difference exceeded the uncertainty limits for the difference, merit additional attention. If an explanation other than the phenomenon being studied caused the anomaly, then the test was passed. If not, the test was failed.

\subsection{Data Integrity Review}

The data qualification methods were applied to the data streams by measurement type. The results of the checks for range, stability, consistency, precision and accuracy for each measurement type were presented in detail in reference [1].

Tables 17 through 27 provide the final results from this process. For each test, each data stream is identified, its average (from the raw measurements) is given, an estimate of precision (twice the standard deviation) is provided, the bias is estimated (for QUALIFIED data), and the quality label is assigned.

Comments pertinent to the label assignment for each measurement type are summarized in this section. 


\section{Process Water Temperature}

Process water temperatures were recorded at pump suction and in each of the two heat exchanger outlet pipes for each loop. The temperatures from the outlet pipes are the plenum inlet water temperatures for that loop. In each loop, one of three different RTDs measured each of these three temperatures. The pump suction water temperatures were recorded on Data Sheet \#1 and $\# 2$ and the plenum inlet water temperatures were recorded on Data Sheet \#2.

Pump suction water temperatures were controlled and maintained within a specified range for "cold" versus "warm" tests to establish steady-state processing. Patterns of behavior in the data stream reflected this fact.

These measurements were reviewed together and were used to estimate process water temperature for each test. These temperature estimates were needed to make the ACDATA3 and PLENUM2 adjustments. The pump suction water temperatures from Data Sheet \#1 were used as the process water temperature for all tests except for Test $K$. The data for Test $\mathrm{K}$ on Data Sheet \#1 included only one value for each loop. The pump suction water temperatures from Data Sheet \#2 had more values and were used to determine a process water temperature for Test $\mathrm{K}$.

These water temperatures were assigned the label CONDITIONALLY QUALIFIED (except in situations where no measurements were recorded, these data streams were FAILED). The "conditional" reflects the fact that no uncertainty information or calibration information corresponding to the RTD's used for the 1985 tests was available.

\section{Barometric Pressure}

These data were used to adjust gauge pressure measurements to pounds per square inch absolute. They were not truly steadystate data since these data streams could only be monitored during the testing. The review of these data revealed no problems such as recording errors or outliers. However, no 
information was available regarding the instrumentation used for these measurements; thus, these data have been assigned the label "CONDITIONALLY QUALIFIED."

\section{Ultrasonic Flowmeter Measurements}

Three ultrasonic flowmeters were used during these tests. One remained in loop 1 for all eleven tests while the other two were placed in other loops for each of the tests. Table 4 provides the details of these placements as well as zero offset values which were recorded in the laboratory notebook during the testing [7].

All five of the DQ checks were applied to these data including comparisons to flow data from the the L-Area tests conducted in 1989. The comparisons provided a limited opportunity for accuracy checks. No problems were found in areas where appropriate checks could be identified. Since no specific calibration information was available for the flowmeters used during these tests, the uncertainty in the measurements could not be adequately estimated. For these reasons the flow data streams were assigned the "CONDITIONALLY QUALIFIED" label.

\section{Plenum Centerline Pressures}

Two plenum centerline pressure data streams were recorded for each test - one on the paper tape from System "A" and one on the data sheets from System "B." More measurements were taken on the paper tapes, but the data from the data sheets were adequate for review.

All DQ checks were applied and no problems found. In fact, since two instruments were involved in the measuring process, a comparison of the average data sheet pressure versus the average paper tape pressure provided a very good accuracy check for each test. These results lead to the assignment of "QUALIFIED" for the plenum centerline pressures. 


\section{Tank Bottom Pressures}

Five tank bottom pressure data streams were recorded for each test: one data stream for LPH readings, one for GANG1 readings, and one for each of three OLC locations.

No problems were discovered in the application of the DQ checks. The accuracy check was facilitated by a tank level test that was conducted during the testing and documented in the logbook [8]. These results lead to the "QUALIFIED" label being assigned to these data streams.

\section{Pump Suction Pressures}

All of the DQ checks were applied to these data. Some minor trends were revealed in the time plot of the data streams for some tests, but these slight stability problems were considered to be of little practical concern. A redundancy to qualified $1989 \mathrm{~L}$ Area data for Test B and consistency of the 1985 tests were confirmed by the other DQ checks. Also, pre-test information including a calibration traceable to an NIST standard for the Heise gauge used for these measurements were documented. The "QUALIFIED" label was assigned to these data streams.

\section{Pump Discharge Pressures}

The stability check for these data revealed a common pattern of behavior across all loops for tests $G$ and $J$. These patterns were found to be similar to those demonstrated by water temperatures and were believed to reflect actual system conditions. No instrument problems were involved. Pre-test information including a calibration traceable to NIST standards was available. An historical redundancy to the qualified 1989 L-Area data and consistency results across the 1985 tests allowed for assignment of a "QUALIFIED" label.

\section{Heat Exchanger Inlet Pressures}

The stability checks for these data revealed a pattern for tests $G$ and $\mathrm{J}$. These pressure measurements were demonstrating behavior similar to that seen in the pump discharge pressures. 
Once again, these patterns were not considered to be a problem with the instrumentation, bui to reflect actual operating conditions.

All the other DQ checks revealed no problems and the calibration information for the Heise gauge providing the measurements was available. The "QUALIFIED" label was assigned.

\section{Heat Exchanger Discharge Pressures}

All five of the $D Q$ checks were made on these data. No problems were discovered. Pre-test information including a calibration traceable to NIST standards were available for the Heise gauge providing these measurements. Redundancy to qualified 1989 data and consistency of results across the 1985 tests allowed for assignment of the "QUALIFIED" label.

\section{ECS Pressures}

Checks for range, stability, consistency and precision revealed no probiems for these data. However, no accuracy check was identified for these data streams. Although calibration information is available for the Heise gauge used for these measurements, the "CONDITIONALLY QUALIFIED" label is assigned since no accuracy check could be made.

\section{Plenum Pressures}

The ninety data streams providing plenum pressures for each test were reviewed extensively. The range, stability and precision checks were quickiy applied without any problems being discovered except for OLC 487 . The measurements for OLC 487 demonstrated significant problems for some tests and those data streams have been FAILED.

The checks for consistency and accuracy were difficult. This was because of the complexity of behaviors of the pressures in the plenum. Numerous comparisons among the tests were attempted with some success. Tests whose processing conditions differed only by temperature produced pressure facemaps that were 
similar. Quantitative models based on an analysis of variance approach for the symmetric tests (A,B,C,G,H \& I) provided evidence of consistency of measurements, but a pattern in the residual plots for these was also revealed. These patterns suggested that the plenum pressure behavior was more complex than these models were capable of estimating. A comparison of facemaps plots of these residuals revealed similar behavior in the residuals from tests that differed only by temperature (A-G, B-H and $C-I)$. The patterns in the residuals were related to positional differences.

The only accuracy check available for these data streams was to compare the derived plenum centerline pressure from PLENUM2 to that measured with System "B." The comparisons, which could be made at only two OLC's, 1 and 6, for each test, provided good but limited results.

Information for calibration and uncertainties was available for the Heise gauge used for these measurements. However, since accuracy checks were possible for only 2 OLC's for each test, these data streams (except where noted for OLC 487) were assigned the label "CONDITIONALLY QUALIFIED."

\subsection{Conclusions}

The Data Qualification process was a formal evaluation of the test data based on evidence provided by the data themselves using engineering and statistical principles. Overall thesi results provide corroborating technical information that the data from the 1985 tests were representative of the processes being tested. 


\subsection{References}

[1] Edwards, T.B., D.A. Eghbali, M.L. Liebmann, \& E.P. Shine, "Data Qualification for 1985 L-Area AC Flow Tests," SCS-CMAS-910045, December 31, 1991.

[2] Special Procedure No. SP-2363 (TA 1-2200), "AC Process Flow Test," February 14, 1985.

[3] L. D. Koffman, et. al., "TRAC Calculations of the Initial Flow Decay in L-1.1," DPST-87-737, December 18, 1987.

[4] M. L. Liebmann, "Technical Review ACDATA2 and PLENUM Programs," Task 91-033-1, July 23, 1991.

[5] Dresser Industrial Instrument Operations, "Calibration Certification Report," Serial Nos. S7-18478, S7-18457, S7-18456, S7-18455 \& S7-18455, February 18, 1985 (included with Invoice No. 3GH-L1919 and Purchase Requisition T42596).

[6] "Heise Installation and Operating Instructions for Series 7 Digital Pressure Indicators," Dresser Industries, May, 1983.

[7] Laboratory Notebook No. E37297, pages 1 through 31.

[8] Laboratory Notebook No. E37312, pages 1 through 57.

[9] D.A. Eghbali, "Pump Suction and Plenum Inlet Temperature Measurement Uncertainties (U)," NES-ETH-910479, September 16, 1991.

[10] Controlotron Instruction Manual, 480IM-4a, "Series 480 Clamp-On Flowmeter, " January 23, 1984.

[11] S. M. Mertz, "Plenum Pressure Measurement Uncertainties (U)," WSRC-TR-90-42-121, January 2, 1991.

[12] Memorandum, L. D. Koffman to T. B. Edwards, "Comments on NESART-910216," NES-CDG-910132, July 30, 1.991. 
[13] Memorandum, N. M. Askew to T.B. Edwards, "Corrections to the PLENUM2 Spreadsheet," NES-ART-910341, August 20, 1991.

[14] L. L. Hamm and M. A. McClain, "New Bingham Pump Head Curves," DPST-85-906 (DRAFT), August 19, 1985.

[15] L. D. Koffman, "TRAC Core Generator," DPST-88-642, August 11, 1988.

[16] R. P. Evans, et. al., "Savannah River Laboratory Qualification Manual," EG\&G Idaho, Inc., May 1990 (Draft).

[17] Memorandum, D. A. Eghbali to T. B. Edwards, "1989 L Reactor Qualified Data," NES-ETH-910230, April 15, 1991. 
14.0 Tables

TABLE 1

\section{L-Area AC Flow Test Configurations}

$\begin{array}{ccccc}\text { Test } & \begin{array}{c}\text { Pumps On } \\ \text { (Loops) }\end{array} & \begin{array}{c}\text { Septifoil } \\ \text { Position }\end{array} & \begin{array}{c}\text { Rotovalves } \\ \text { Open }\end{array} & \begin{array}{c}\text { Process } \\ \text { Temp }\end{array} \\ \text { A } & 1-6 & \text { off } & \text { A only } & \text { cold } \\ \text { B } & 1-6 & \text { off } & \text { A and B } & \text { cold } \\ \text { C } & 1-6 & \text { on } & \text { A and B } & \text { cold } \\ \text { D } & 1-5 & \text { off } & \text { A and B } & \text { cold } \\ \text { E } & 2-6 & \text { off } & \text { A and B } & \text { cold } \\ \text { F } & 1,3,5 & \text { off } & \text { A and B } & \text { cold } \\ \text { G } & 1-6 & \text { off } & \text { A only } & \text { warm } \\ \text { H } & 1-6 & \text { off } & \text { A and B } & \text { warm } \\ \text { I } & 1-6 & \text { on } & \text { A and B } & \text { warm } \\ \text { J } & 2-6 & \text { off } & \text { A and B } & \text { warm } \\ \text { K } & 1,3,6 & \text { off } & \text { A and B } & \text { warm }\end{array}$


TABLE 2

PLENUM PRESSURE MEASUREMENTS

OLC Location and Scani Valve Position

\begin{tabular}{|c|c|c|c|c|c|c|c|c|c|c|c|}
\hline $\begin{array}{l}\text { Flow } \\
\text { Zone }\end{array}$ & $\begin{array}{l}\text { Fuel } \\
\text { Ass'y }\end{array}$ & ac & $\begin{array}{c}X \\
\text { Coordi na }\end{array}$ & $\begin{array}{l}Y \\
108\end{array}$ & $\begin{array}{c}\text { Scani Valve } \\
\text { A Pos'n }\end{array}$ & $\begin{array}{l}\text { Flow } \\
\text { Zone }\end{array}$ & $\begin{array}{l}\text { Fuel } \\
\text { Ass'y }\end{array}$ & $\underset{*}{a c}$ & $\begin{array}{c}x \\
\text { Coordi na }\end{array}$ & $\begin{array}{l}Y \\
\text { ces }\end{array}$ & $\begin{array}{c}\text { Scani Valve } \\
\text { B Pos'n }\end{array}$ \\
\hline 0 & NOFlOW & 539 & 31 & 3 & 1 & 4 & MK16B & 432 & 17 & 15 & 1 \\
\hline 0 & NOFLOW & 542 & 27 & 3 & 2 & 3 & MK16B & 280 & 35 & 15 & 2 \\
\hline 0 & NOFLOW & 524 & 49 & 21 & 3 & 9 & MK31A & 406 & 43 & 21 & 3 \\
\hline 0 & NOFLOW & 559 & 7 & 21 & 4 & 7 & MK31A & 161 & 29 & 21 & 4 \\
\hline 0 & NOFLOW & 562 & 5 & 27 & 5 & 7 & MK31A & 295 & 23 & 21 & 5 \\
\hline 0 & NOFLOW & 520 & 51 & 27 & 6 & 7 & MK31A & 177 & 17 & 27 & 6 \\
\hline 0 & NOFLDW & 512 & 55 & 51 & 7 & 1 & MK16B & 148 & 38 & 30 & 7 \\
\hline 0 & NOFLOW & 510 & 54 & 54 & 8 & 7 & MK31A & 71 & 31 & 33 & 8 \\
\hline 0 & NOFlOW & 508 & 53 & 57 & 9 & 7 & MK31A & 83 & 21 & 33 & 9 \\
\hline 0 & NOFlOW & 506 & 53 & 63 & 10 & 7 & MK31A & 313 & 12 & 36 & 10 \\
\hline 0 & NOFLOW & 504 & 52 & 66 & 11 & 7 & MK31A & 263 & 46 & 36 & 11 \\
\hline 0 & NOFLOW & 579 & 4 & 66 & 12 & 1 & MK168 & 182 & 17 & 39 & 12 \\
\hline 0 & NOFlOW & 502 & 51 & 69 & 13 & 1 & MK16B & 26 & 26 & 42 & 13 \\
\hline 0 & NOFLOW & 500 & 50 & 72 & 14 & 7 & MK31A & 15 & 34 & 42 & 14 \\
\hline 0 & NOFLOW & 582 & 6 & 72 & 15 & 7 & MK31A & 135 & 43 & 45 & 15 \\
\hline 0 & NOFLOW & 499 & 49 & 75 & 16 & 4 & MK16B & 450 & 7 & 45 & 16 \\
\hline 0 & NOFLOW & 488 & 48 & 78 & 17 & 1 & MK16B & 34 & 22 & 48 & 17 \\
\hline 0 & NOFLOW & 496 & 45 & 81 & 18 & 7 & MK31A & 1 & 29 & 51 & 18 \\
\hline 0 & NOFLOW & 497 & 47 & 81 & 19 & 1 & MK16B & 6 & 27 & 51 & 19 \\
\hline 0 & NOFLOW & 495 & 44 & 84 & 20 & 1 & MK168 & 59 & 36 & 54 & 20 \\
\hline 0 & NOFLOW & 593 & 15 & 87 & 21 & 7 & MK31A & 129 & 42 & 54 & 21 \\
\hline 0 & NOFlOW & 493 & 41 & 87 & 22 & 3 & MK16B & 248 & 48 & 54 & 22 \\
\hline 0 & NOFlOW & 494 & 43 & 87 & 23 & 10 & MK31A & 508 & 52 & 54 & 23 \\
\hline 0 & NOFLOW & 492 & 40 & 90 & 24 & 6 & MK168 & 507 & 52 & 60 & 24 \\
\hline 0 & NOFLOW & 490 & 38 & 90 & 25 & 7 & MK31A & 243 & 46 & 60 & 25 \\
\hline 0 & NOFLOW & 488 & 36 & 90 & 26 & 1 & MK168 & 198 & 12 & 60 & 26 \\
\hline 0 & NOFLOW & 596 & 20 & 90 & 27 & 1 & MK168 & 106 & 25 & 63 & 27 \\
\hline 0 & NOFLOW & 595 & 18 & 90 & 28 & 7 & MK31A & 47 & 29 & 63 & 28 \\
\hline 0 & NOFLOW & 592 & 13 & 87 & 29 & 1 & MK16B & 124 & 39 & 63 & 29 \\
\hline 0 & NOFLOW & 597 & 21 & 93 & 30 & 4 & MK16B & 382 & 48 & 66 & 30 \\
\hline 0 & NOFLW & 598 & 23 & 93 & 31 & 2 & MK16B & 238 & 43 & 69 & 31 \\
\hline 0 & NOFLOW & 589 & 25 & 93 & 32 & 3 & MK16B & 236 & 46 & 72 & 32 \\
\hline 0 & NOFLOW & 600 & 27 & 93 & 33 & 7 & MK31A & 115 & 36 & 72 & 33 \\
\hline 0 & NOFLOW & 482 & 29 & 93 & 34 & 1 & MK168 & 110 & 32 & 72 & 34 \\
\hline 0 & NOFlOW & 484 & 31 & 93 & 35 & 1 & MK16B - & 214 & 24 & 72 & 35 \\
\hline 0 & NOFLOW & 486 & 33 & 93 & 36 & 1 & MK16B & 210 & 20 & 72 & 36 \\
\hline 10 & MK31A & 487 & 34 & 90 & 37 & 3 & MK168 & 230 & 41 & 75 & 37 \\
\hline 10 & MK31A & 491 & 39 & 87 & 38 & 10 & MK31A & 377 & 44 & 78 & 38 \\
\hline 20 & PUG & & & & 39 & 20 & PUS & & & & 39 \\
\hline 5 & MK16B & 367 & 35 & 87 & 40 & 4 & MK168 & 472 & 17 & 81 & 40 \\
\hline 9 & MK31A & 363 & 31 & 87 & 41 & 3 & MK16B & 354 & 19 & 81 & 41 \\
\hline 4 & MK16B & 361 & 27 & 87 & 42 & 2 & MK168 & 358 & 23 & 81 & 42 \\
\hline 3 & MK16B & 360 & 23 & 87 & 43 & 7 & MK31A & 221 & 27 & 81 & 43 \\
\hline 10 & MK31A & 475 & 19 & 87 & 44 & 2 & MK16B & 218 & 31 & 81 & 44 \\
\hline 9 & MK31A & 471 & 16 & 84 & 45 & 8 & MK31A & 223 & 35. & 81 & 45 \\
\hline 6 & MK168 & 373 & 42 & 84 & 46 & 8 & MK31A & 372 & 39 & 81 & 46 \\
\hline 20 & Pua & & & & 47 & 20 & PUa & & & & 47 \\
\hline 20 & PUa & & & & 48 & 20 & pus & & & & 48 \\
\hline
\end{tabular}


TABLE 3

SCANI VALVE POSITIONS AND LOOP PRESSUFIE TAP LOCATIONS

Scani Valve A

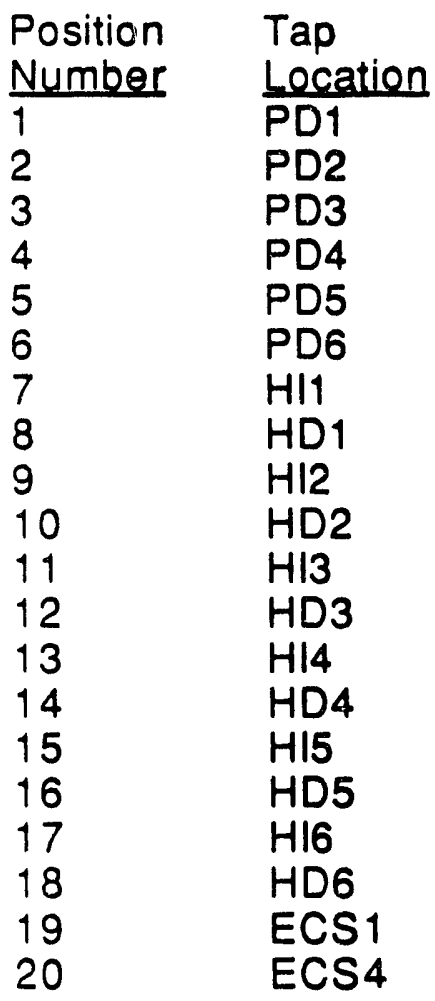

Scani Valve B

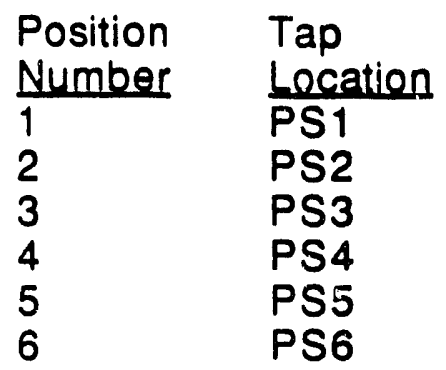

KEY

HD heat exchanger discharge

HI heat exchanger inlet

ECS ECS line

PS pump suction

PD pump discharge

\# loop/system number 


\section{Table 4}

Test Sequence \& Ultrasonic Flowmeter Placement

Ultrasonic - a Ultrasonic - b Ultrasonic - c

\section{Test Sequence}

B

A

D

E

F

C

G

H

I

J

K

(zero offset)

gpM

\begin{tabular}{llllll}
\multicolumn{1}{c}{$\begin{array}{l}\text { L OOP S } \\
1\end{array} \quad 2$} & 3 & 4 & 5 & 6
\end{tabular}

a $\quad-\quad-\quad-\quad b \quad c$

a - - - b c

$(-635)$

a $\quad-\quad$ c b

$(-260)$

a - $c$ c b .

$a-c^{(-260)}$ b.

$(-250)$

a - c - - b

$(-250) \quad(-980)$

a - c - - b

$(-250)$

$(-980)$

a - c - - b

$(-250) \quad(-980)$

a - c - - b

$(-250) \quad(-980)$

a - c - - b

$(-250) \quad(-980)$

a - c - - b

$(-250) \quad(-980)$ 


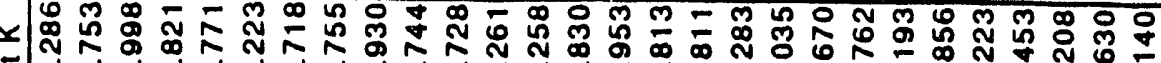

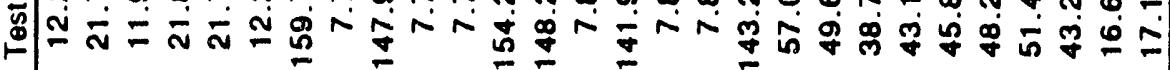

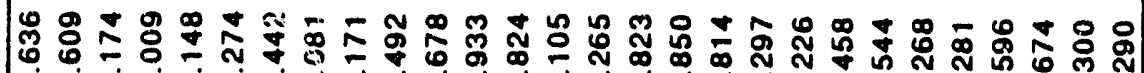

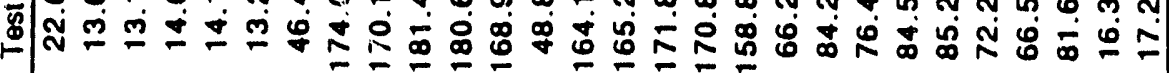

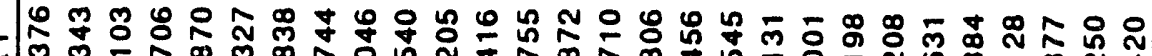

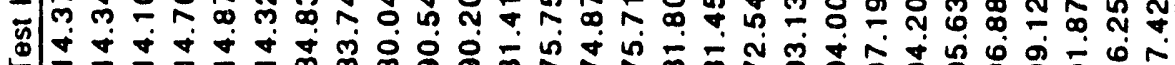

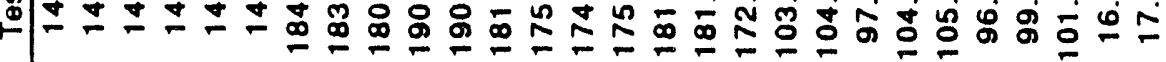

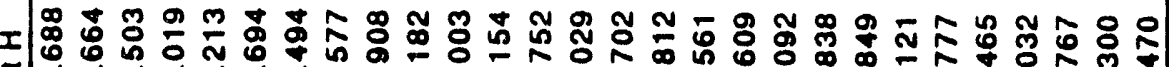

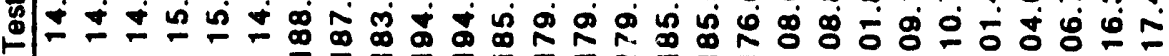

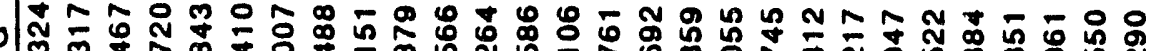

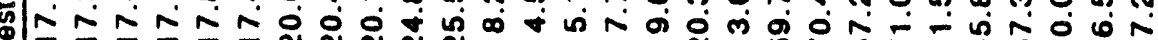

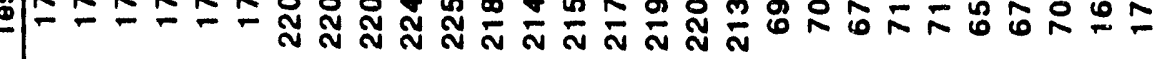

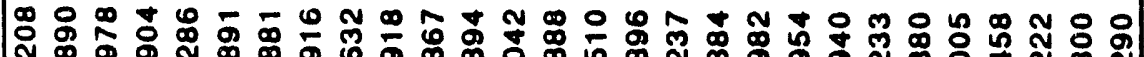

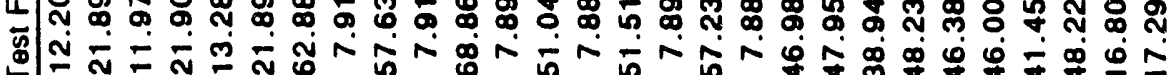

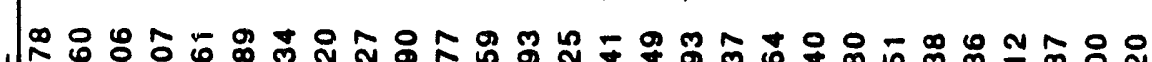

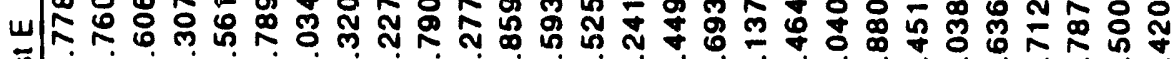

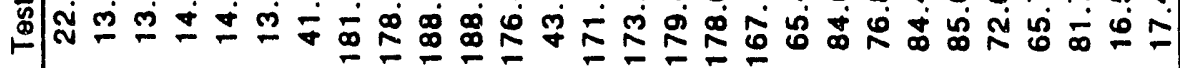

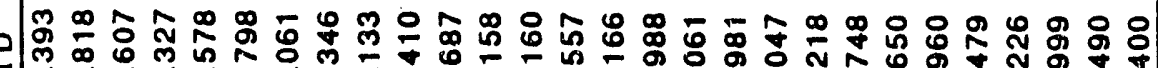

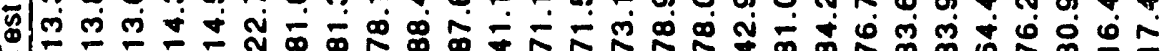

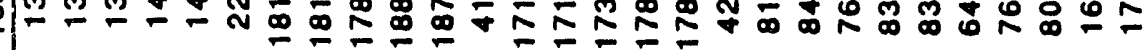

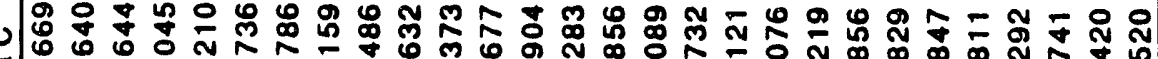

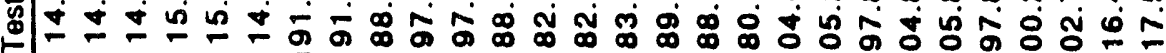

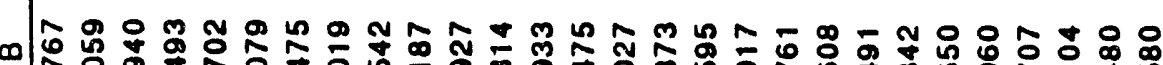

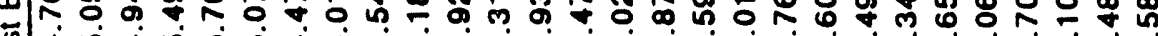

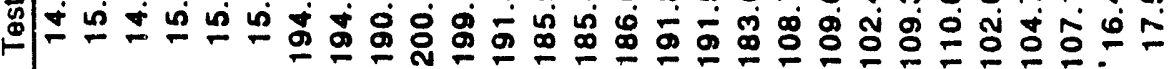

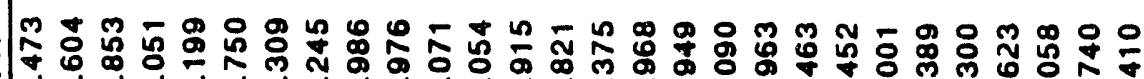
商人
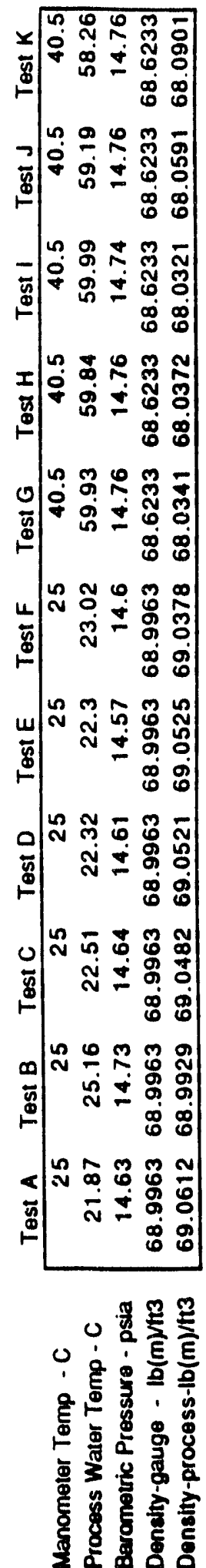


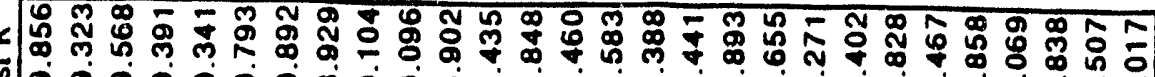
คำ ล

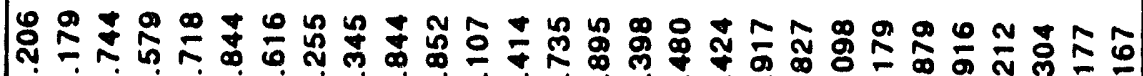

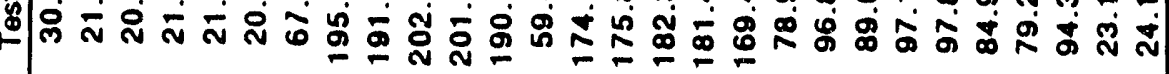

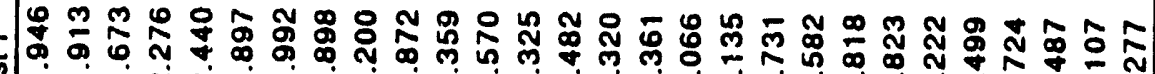

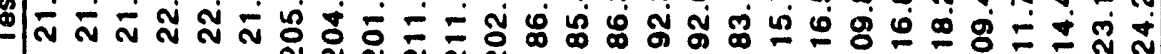

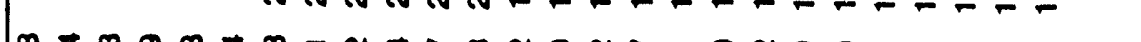

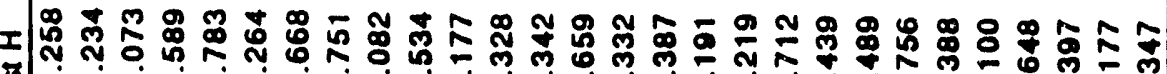

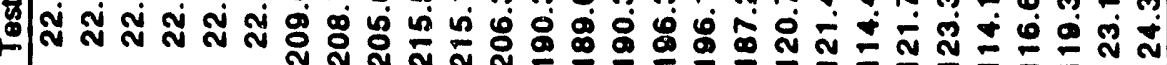

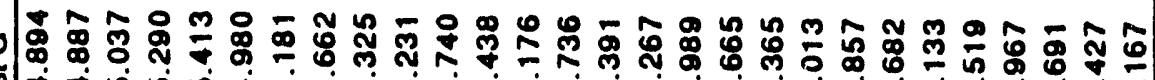

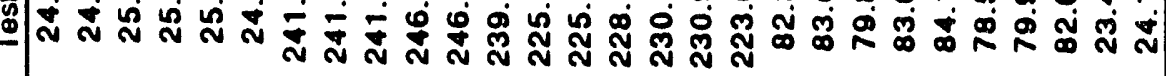
ᄂ

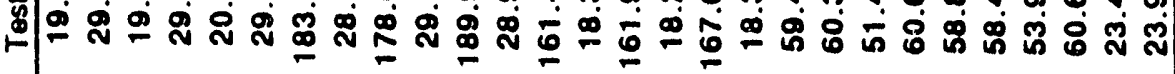

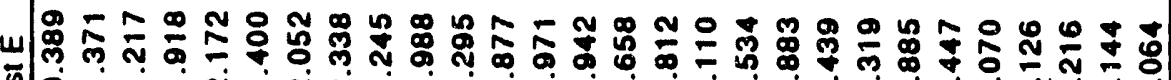
車价

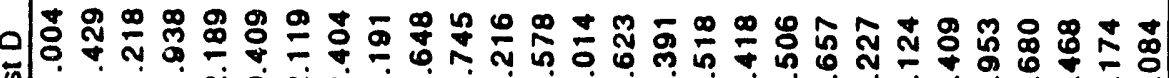

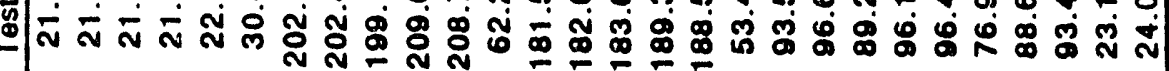

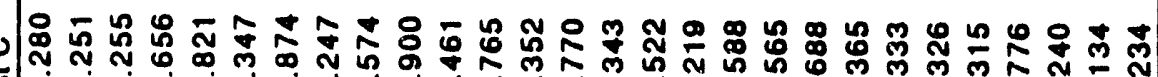

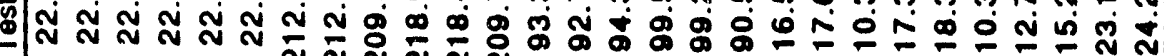

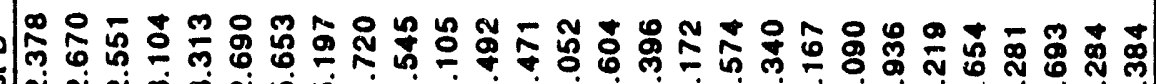

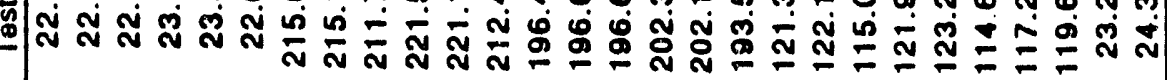

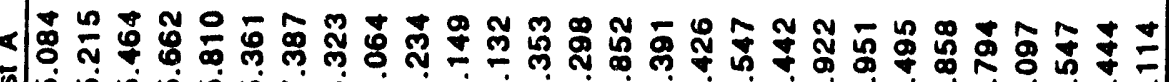

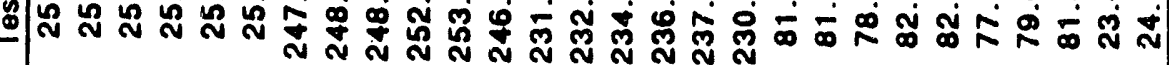




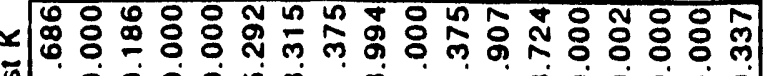

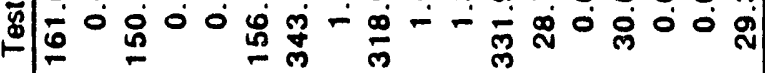

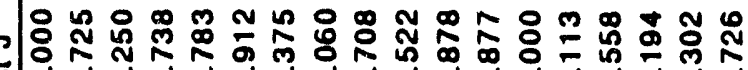

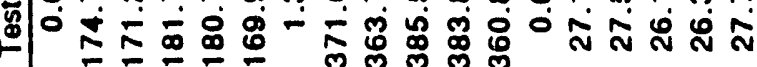
ก O O

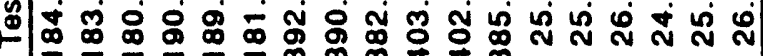
용요

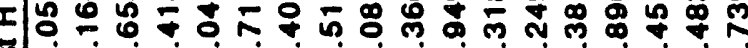

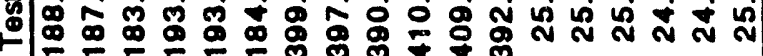

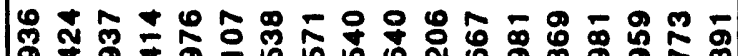

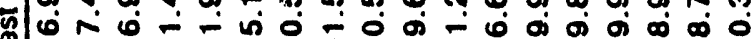
六

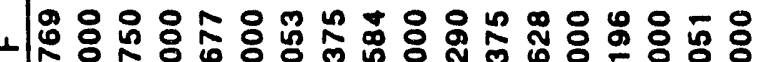

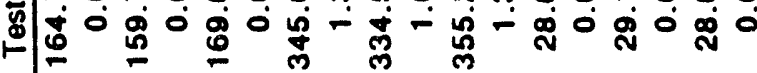

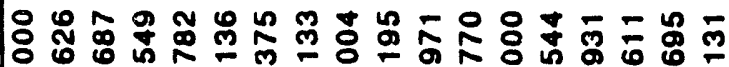

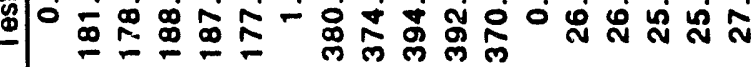

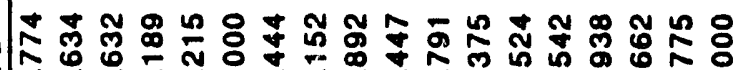

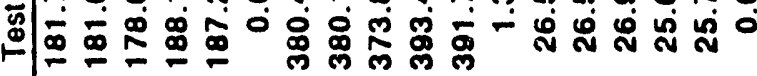

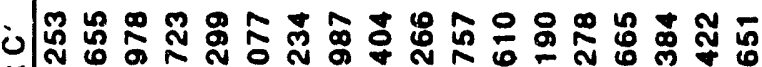

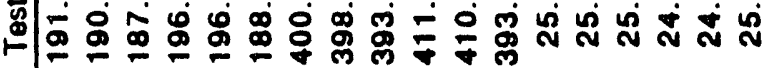

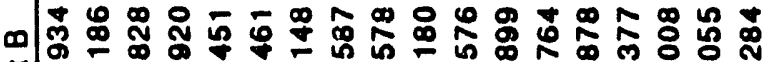

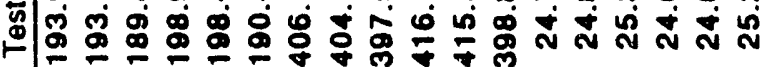

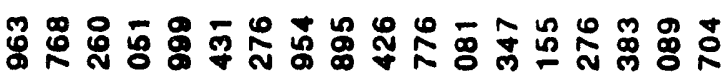

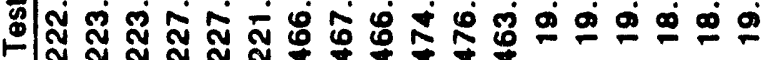


Table 6 ... PLENUM2 for Test A

\begin{tabular}{|c|c|c|c|c|c|}
\hline OLC & $\begin{array}{l}\text { Measured } \\
\text { Pressure } \\
\text { Inside USH } \\
\text { (psig) } \\
\end{array}$ & $\begin{array}{l}\text { Corrected } \\
\text { Pressure } \\
\text { Outside USH } \\
\text { (psig) }\end{array}$ & $\begin{array}{l}\text { Corrected } \\
\text { Head Outside } \\
\text { USH } \\
\text { (fi) }\end{array}$ & $\begin{array}{l}\text { Calculated } \\
\text { Assembly } \\
\text { Flow } \\
\text { (gpm) } \\
\end{array}$ & $\begin{array}{l}\text { Adjusted } \\
\text { Plenum C-L } \\
\text { Pressure } \\
\text { (psig) } \\
\end{array}$ \\
\hline 1 & 45.92 & 46.89 & 97.07 & 179.24 & 47.06 \\
\hline 6 & 43.86 & 46.67 & 92.78 & 313.57 & 46.84 \\
\hline 15 & 45.67 & 46.63 & 96.55 & 178.73 & 46.80 \\
\hline 26 & 44.27 & 47.10 & 93.63 & 315.06 & 47.28 \\
\hline 34 & 43.76 & 46.56 & 92.57 & 313.21 & 46.74 \\
\hline 47 & 45.32 & 46.27 & 95.81 & 178.01 & 46.44 \\
\hline 59 & 44.32 & 47.16 & 93.74 & 315.24 & 47.33 \\
\hline 71 & 45.72 & 46.68 & 96.65 & 178.83 & 46.85 \\
\hline 83 & 45.10 & 46.05 & 95.36 & 177.57 & 46.22 \\
\hline 106 & 42.84 & 45.59 & 90.65 & 309.85 & 45.76 \\
\hline 110 & 45.62 & 48.54 & 96.44 & 319.90 & 48.71 \\
\hline 115 & 48.87 & 49.89 & 103.21 & 185.12 & 50.06 \\
\hline 124 & 43.19 & 45.95 & 91.38 & 311.12 & 46.13 \\
\hline 129 & 45.50 & 46.45 & 96.18 & 178.37 & 46.62 \\
\hline 135 & 45.48 & 46.44 & 96.16 & 178.34 & 46.61 \\
\hline 148 & 44.65 & 47.50 & 94.41 & 316.41 & 47.68 \\
\hline 161 & 46.86 & 47.84 & 99.03 & 181.13 & 48.02 \\
\hline 177 & 45.57 & 46.5 .2 & 96.34 & 178.52 & 46.70 \\
\hline 182 & 43.55 & 46.34 & 92.13 & 312.44 & 46.51 \\
\hline 198 & 45.76 & 48.69 & 96.74 & 320.41 & 48.86 \\
\hline 210 & 42.71 & 45.44 & 90.37 & 309.36 & 45.62 \\
\hline 214 & 43.10 & 45.86 & 91.19 & 310.80 & 46.04 \\
\hline 218 & 47.24 & 50.26 & 99.83 & 325.64 & 50.44 \\
\hline 221 & 47.17 & 48.16 & 99.67 & 181.75 & 48.33 \\
\hline 223 & 52.72 & 53.50 & 111.24 & 161.33 & 53.68 \\
\hline 230 & 50.70 & 53.37 & 107.04 & 305.29 & 53.54 \\
\hline 236 & 48.33 & 50.88 & 102.09 & 297.97 & 51.05 \\
\hline 238 & 43.71 & 46.51 & 92.46 & 313.02 & 46.68 \\
\hline 243 & 46.14 & 47.10 & 97.52 & 179.67 & 47.28 \\
\hline 248 & 43.50 & 45.80 & 92.03 & 282.53 & 45.98 \\
\hline 263 & 47.02 & 48.01 & 99.37 & 181.46 & 48.18 \\
\hline 280 & 49.81 & 52.43 & 105.18 & 302.56 & 52.61 \\
\hline 295 & 45.77 & 46.73 & 96.75 & 178.92 & 46.90 \\
\hline 313 & 49.21 & 50.24 & 103.93 & 185.79 & 50.41 \\
\hline 354 & 44.04 & 46.36 & 93.14 & 284.28 & 46.54 \\
\hline 358 & 43.69 & 46.49 & 92.42 & 312.96 & 46.66 \\
\hline 360 & 44.70 & 47.06 & 94.53 & 286.43 & 47.23 \\
\hline 361 & 47.11 & 49.33 & 99.54 & 277.38 & 49.50 \\
\hline
\end{tabular}


Table 6 ... PLENUM2 for Test A

\begin{tabular}{|c|c|c|c|c|c|}
\hline OL & $\begin{array}{l}\text { Measured } \\
\text { Pressure } \\
\text { Inside USH } \\
\text { (psig) }\end{array}$ & $\begin{array}{c}\text { Corrected } \\
\text { Pressure } \\
\text { Outside USH } \\
\text { (psig) } \\
\end{array}$ & $\begin{array}{l}\text { Corrected } \\
\text { Head Outside } \\
\text { USH } \\
\text { (fi) }\end{array}$ & $\begin{array}{l}\text { Calculated } \\
\text { Assembly } \\
\text { Flow } \\
\text { (gpm) }\end{array}$ & $\begin{array}{l}\text { Adjusted } \\
\text { Plenum C-L } \\
\text { Pressure } \\
\text { (psig) }\end{array}$ \\
\hline 363 & 53.15 & 53.67 & 112.15 & 129.44 & 53.84 \\
\hline 367 & 53.92 & 55.08 & 113.74 & 198.22 & 55.26 \\
\hline 372 & 54.28 & 55.09 & 114.50 & 163.77 & 55.26 \\
\hline 373 & 57.73 & 58.49 & 121.70 & 158.17 & 58.66 \\
\hline 377 & 56.15 & 56.43 & 118.40 & 94.82 & 56.60 \\
\hline 382 & 44.49 & 46.59 & 94.09 & 269.50 & 46.77 \\
\hline 406 & 54.28 & 54.80 & 114.50 & 130.82 & 54.98 \\
\hline 432 & 45.21 & 47.35 & 95.59 & 271.70 & 47.52 \\
\hline 450 & 52.22 & 54.68 & 110.21 & 292.20 & 54.85 \\
\hline 471 & 48.02 & 48.48 & 101.44 & 122.95 & 48.66 \\
\hline 472 & 43.88 & 45.95 & 92.81 & 267.61 & 46.12 \\
\hline 475 & 51.33 & 51.58 & 108.34 & 90.66 & 51.76 \\
\hline 482 & 57.86 & 57.86 & 121.96 & 0.00 & 58.03 \\
\hline 484 & 58.66 & 58.66 & 123.64 & 0.00 & 58.84 \\
\hline 486 & 60.14 & 60.14 & 126.72 & 0.00 & 60.31 \\
\hline 487 & $\cdot$ & $\cdot$ & $\cdot$ & - & $\cdot$ \\
\hline 488 & 57.21 & 57.21 & 120.61 & 0.00 & 57.39 \\
\hline 490 & 60.79 & 60.79 & 128.06 & 0.00 & 60.96 \\
\hline 491 & 58.31 & 58.59 & 122.89 & 96.63 & 58.77 \\
\hline 492 & 60.54 & 60.54 & 127.54 & 0.00 & 60.71 \\
\hline 493 & 59.43 & 59.43 & 125.23 & 0.00 & 59.60 \\
\hline 494 & 60.67 & 60.67 & 127.82 & 0.00 & 60.84 \\
\hline 495 & 60.08 & 60.08 & 126.59 & 0.00 & 60.26 \\
\hline 496 & 57.61 & 57.61 & 121.44 & 0.00 & 57.78 \\
\hline 497 & 60.63 & 60.63 & 127.74 & 0.00 & 60.81 \\
\hline 498 & 60.15 & 60.15 & 126.74 & 0.00 & 60.32 \\
\hline 499 & 57.97 & 57.97 & 122.19 & 0.00 & 58.14 \\
\hline 500 & 56.63 & 56.63 & 119.40 & 0.00 & 56.80 \\
\hline 502 & 57.37 & 57.37 & 120.94 & 0.00 & 57.55 \\
\hline 504 & 55.52 & 55.52 & 117.09 & 0.00 & 55.70 \\
\hline 506 & 53.28 & 53.28 & 112.41 & 0.00 & 53.45 \\
\hline 507 & 48.45 & 49.09 & 102.35 & 144.98 & 49.27 \\
\hline 508 & 53.88 & 53.88 & 113.67 & 0.00 & 54.06 \\
\hline 509 & 50.99 & 51.24 & 107.64 & 90.36 & 51.42 \\
\hline 510 & 54.80 & 54.80 & 115.58 & 0.00 & 54.98 \\
\hline 512 & 55.73 & 55.73 & 117.51 & 0.00 & 55.90 \\
\hline 520 & 58.24 & 58.24 & 122.76 & 0.00 & 58.42 \\
\hline 524 & 59.42 & 59.42 & 125.21 & 0.00 & 59.59 \\
\hline
\end{tabular}


WSRC-TR-92-134

Task 91-033-1

DQ Summary for 1985 L-Area AC Flow Tests
March 10, 1992

Revision 0

Page 34 of 119

Table 6 ... PLENUM2 for Test A

\begin{tabular}{|cccccc|} 
OLC & $\begin{array}{c}\text { Measured } \\
\text { Pressure } \\
\text { Inside USH } \\
\text { (psig) }\end{array}$ & $\begin{array}{c}\text { Corrected } \\
\text { Pressure } \\
\text { Outside USH } \\
\text { (psig) }\end{array}$ & $\begin{array}{c}\text { Corrected } \\
\text { Head Outside } \\
\text { USH } \\
\text { (fi) }\end{array}$ & $\begin{array}{c}\text { Calculated } \\
\text { Assembly } \\
\text { Flow } \\
\text { (gpm) }\end{array}$ & $\begin{array}{c}\text { Adjusted } \\
\text { Plenum C-L } \\
\text { Pressure } \\
\text { (psig) }\end{array}$ \\
\hline 539 & 57.79 & 57.79 & 121.82 & 0.00 & 57.97 \\
542 & 57.67 & 57.67 & 121.57 & 0.00 & 57.85 \\
559 & 58.55 & 58.55 & 123.39 & 0.00 & 58.72 \\
562 & 60.65 & 60.65 & 127.78 & 0.00 & 60.83 \\
579 & 58.52 & 58.52 & 123.34 & 0.00 & 58.69 \\
582 & 58.46 & 58.46 & 123.22 & 0.00 & 58.64 \\
592 & 56.68 & 56.68 & 119.50 & 0.00 & 56.85 \\
593 & 55.47 & 55.47 & 116.98 & 0.00 & 55.64 \\
595 & 54.63 & 54.63 & 115.22 & 0.00 & 54.80 \\
596 & 53.76 & 53.76 & 113.42 & 0.00 & 53.94 \\
597 & 51.94 & 51.94 & 109.62 & 0.00 & 52.12 \\
598 & 53.32 & 53.32 & 112.49 & 0.00 & 53.49 \\
599 & 56.25 & 56.25 & 118.61 & 0.00 & 56.43 \\
600 & 57.38 & 57.38 & 120.97 & 0.00 & 57.56 \\
\hline
\end{tabular}


Table 7 ... PLENUM2 for Test B

\begin{tabular}{|c|c|c|c|c|c|}
\hline OLC & $\begin{array}{l}\text { Meassured } \\
\text { Pressure } \\
\text { Inside USH } \\
\text { (psig) } \\
\end{array}$ & $\begin{array}{l}\text { Corrected } \\
\text { Pressure } \\
\text { Outside USH } \\
\text { (psig) }\end{array}$ & $\begin{array}{l}\text { Corrected } \\
\text { Head Outside } \\
\text { USH } \\
\text { (ft) }\end{array}$ & $\begin{array}{l}\text { Calculated } \\
\text { Assembly } \\
\text { Flow } \\
\text { (gpm) }\end{array}$ & $\begin{array}{l}\text { Adiusted } \\
\text { Plenum C-L } \\
\text { Pressure } \\
\text { (psig) }\end{array}$ \\
\hline 1 & 75.45 & 77.03 & 158.80 & 232.33 & 77.20 \\
\hline 6 & 71.99 & 76.55 & 151.58 & 403.99 & 76.73 \\
\hline 15 & 75.07 & 16.63 & 158.00 & 231.71 & 76.81 \\
\hline 26 & 72.52 & 77.12 & 152.68 & 405.51 & 77.29 \\
\hline 34 & 71.61 & 76.15 & 150.79 & 402.91 & 76.33 \\
\hline 47 & 74.34 & 75.89 & 156.47 & 230.54 & 76.06 \\
\hline 59 & 72.48 & 77.07 & 152.59 & 405.38 & 77.24 \\
\hline 71 & 75.13 & 76.70 & $158 .\{3$ & 231.82 & 76.88 \\
\hline 83 & 73.95 & 75.49 & 155.66 & 229.90 & 75.67 \\
\hline 106 & 70.29 & 74.75 & 148.03 & 399.10 & 74.92 \\
\hline 110 & 74.79 & 79.53 & 157.43 & 411.96 & 79.71 \\
\hline 115 & 79.97 & 81.64 & 158.23 & 239.49 & 81.82 \\
\hline 124 & 71.24 & 75.76 & 150.01 & 401.84 & 75.93 \\
\hline 129 & 74.79 & 76.35 & 157.42 & 231.27 & 76.53 \\
\hline 135 & 74.37 & 75.93 & 156.55 & 230.59 & 76.10 \\
\hline 148 & 72.97 & 77.59 & 153.61 & 406.78 & 77.76 \\
\hline 161 & 77.23 & 78.84 & 162.51 & 235.17 & 79.02 \\
\hline 177 & 74.65 & 76.21 & 157.13 & 231.04 & 76.38 \\
\hline 182 & 70.81 & 75.30 & 149.10 & 400.58 & 75.47 \\
\hline 198 & 74.84 & 79.58 & 157.52 & 412.08 & 79.76 \\
\hline 210 & 69.35 & 73.75 & 146.06 & 396.35 & 73.92 \\
\hline 214 & 70.11 & 74.55 & 147.65 & 398.56 & 74.73 \\
\hline 218 & 77.45 & 82.35 & 162.96 & 419.36 & 82.53 \\
\hline 221 & 77.24 & 78.85 & 162.53 & 235.18 & 79.03 \\
\hline 223 & 86.60 & 87.88 & 182.06 & 208.36 & 88.05 \\
\hline 230 & 82.37 & 86.65 & 173.24 & 390.86 & 86.83 \\
\hline 236 & 78.54 & 82.62 & 165.24 & 381.51 & 82.80 \\
\hline 238 & 71.26 & 75.78 & $15 i .05$ & 401.89 & 75.95 \\
\hline 243 & 75.69 & 77.27 & 159.29 & 232.71 & 77.44 \\
\hline 248 & 71.20 & 74.91 & 149.92 & 362.94 & 75.08 \\
\hline 263 & 77.71 & 79.33 & 163.51 & 235.93 & 79.51 \\
\hline 280 & 81.72 & 85.96 & 171.88 & 389.28 & 86.14 \\
\hline 295 & 75.24 & 76.81 & 158.36 & 231.99 & 76.99 \\
\hline 313 & 80.97 & 82.66 & 176.32 & 241.05 & 82.84 \\
\hline 354 & 71.77 & 75.51 & 151.11 & 364.42 & 75.68 \\
\hline 358 & 71.69 & 76.23 & 150.94 & 403.12 & 76.41 \\
\hline 360 & 73.24 & 77.06 & 154.18 & 368.20 & 77.23 \\
\hline 361 & 77.60 & 81.20 & 163.28 & 357.33 & 81.37 \\
\hline
\end{tabular}


Table 7 ... PLENUM2 for Test B

\begin{tabular}{|c|c|c|c|c|c|}
\hline Oع & $\begin{array}{l}\text { Measured } \\
\text { Pressure } \\
\text { Inside USH } \\
\text { (psig) } \\
\end{array}$ & $\begin{array}{l}\text { Corrected } \\
\text { Pressure } \\
\text { Outside USH } \\
\text { (psig) } \\
\end{array}$ & $\begin{array}{l}\text { Corrected } \\
\text { Head Outside } \\
\text { LSH } \\
\text { (ft) }\end{array}$ & $\begin{array}{l}\text { Calculated } \\
\text { Assembly } \\
\text { Flow } \\
\text { (gpm) } \\
\end{array}$ & $\begin{array}{l}\text { Adjusted } \\
\text { Plenum } C-L \\
\text { Pressure } \\
\text { (psig) } \\
\end{array}$ \\
\hline 363 & 87.54 & 88.37 & 184.02 & 166.83 & 88.55 \\
\hline 367 & 88.71 & 90.59 & 186.48 & 254.47 & 90.76 \\
\hline 372 & 88.99 & 90.30 & 187.05 & 211.30 & 90.48 \\
\hline 373 & 94.07 & 95.27 & 197.65 & 201.89 & 95.44 \\
\hline 377 & 91.98 & 92.43 & 193.30 & 121.55 & 92.61 \\
\hline 382 & 73.75 & 77.17 & 155.24 & 348.23 & 77.35 \\
\hline 406 & 89.93 & 90.79 & 189.02 & 169.14 & 90.96 \\
\hline 432 & 74.28 & 77.73 & 156.35 & 349.50 & 77.91 \\
\hline 450 & 86.07 & 90.05 & 180.95 & 376.60 & 90.22 \\
\hline 471 & 79.14 & 79.89 & 166.49 & 158.50 & 80.07 \\
\hline 472 & 71.81 & 75.15 & 151.20 & 343.56 & 75.32 \\
\hline 475 & 84.35 & 84.77 & 177.37 & 116.37 & 84.94 \\
\hline 482 & 95.61 & 95.61 & 200.88 & 0.00 & 95.79 \\
\hline 484 & 96.35 & 96.35 & 202.41 & 0.00 & 96.52 \\
\hline 486 & 98.52 & 98.52 & 206.95 & 0.00 & 98.70 \\
\hline 487 & - & $\cdot$ & $\cdot$ & $\cdot$ & $\cdot$ \\
\hline 488 & 94.49 & 94.49 & 198.53 & 0.00 & 94.66 \\
\hline 490 & 99.25 & 99.25 & 208.46 & 0.00 & 99.42 \\
\hline 491 & 95.73 & 96.20 & 201.11 & 124.01 & 36.37 \\
\hline 492 & 99.39 & 99.39 & 208.76 & 0.00 & $: 9.56$ \\
\hline 493 & 97.35 & 97.35 & 204.50 & 0.00 & 37.52 \\
\hline 494 & 99.33 & 99.33 & 208.63 & 0.00 & 99.50 \\
\hline 495 & 98.13 & 98.13 & 206.13 & 0.00 & 98.30 \\
\hline 496 & 94.88 & 94.88 & 199.34 & 0.00 & 95.05 \\
\hline 497 & 98.28 & 98.28 & 206.45 & 0.00 & 98.46 \\
\hline 498 & 98.21 & 98.21 & 206.29 & 0.00 & 98.38 \\
\hline 499 & 95.11 & 95.11 & 199.84 & 0.00 & 95.29 \\
\hline 500 & 92.63 & 92.63 & 194.65 & 0.00 & 92.81 \\
\hline 502 & 95.15 & 95.15 & 199.92 & 0.00 & 95.33 \\
\hline 504 & 94.21 & 94.21 & 197.96 & - 0.00 & 94.39 \\
\hline 506 & 90.56 & 90.56 & 190.34 & 0.00 & 90.74 \\
\hline 507 & 80.63 & 81.71 & 169.70 & 186.99 & 81.89 \\
\hline 508 & 91.74 & 91.74 & 192.79 & 0.00 & 91.91 \\
\hline 509 & 83.63 & 84.04 & 175.87 & 115.87 & 84.22 \\
\hline 510 & 91.01 & 91.01 & 191.28 & 0.00 & 91.19 \\
\hline 512 & 94.21 & 94.21 & 197.96 & 0.00 & 94.39 \\
\hline 520 & 95.79 & 95.79 & 201.25 & 0.00 & 95.96 \\
\hline 524 & 98.01 & 98.01 & 205.88 & 0.00 & .98 .18 \\
\hline
\end{tabular}


Table 7 ... PLENUM2 for Test B

\begin{tabular}{|cccccc|}
\hline OLC & $\begin{array}{c}\text { Measured } \\
\text { Pressure } \\
\text { Inside USH } \\
\text { (psig) }\end{array}$ & $\begin{array}{c}\text { Corrected } \\
\text { Pressure } \\
\text { Outside USH } \\
\text { (psig) }\end{array}$ & $\begin{array}{c}\text { Corrected } \\
\text { Head Outside } \\
\text { USH } \\
\text { (ft) }\end{array}$ & $\begin{array}{c}\text { Calculated } \\
\text { Assembly } \\
\text { Flow } \\
\text { (gpm) }\end{array}$ & $\begin{array}{c}\text { Adjusted } \\
\text { Plenum C-L } \\
\text { Pressure } \\
\text { (psig) }\end{array}$ \\
\hline 539 & 95.54 & 95.54 & 200.72 & 0.00 & 95.71 \\
542 & 94.04 & 94.04 & 197.60 & 0.00 & 94.22 \\
559 & 94.69 & 94.69 & 198.94 & 0.00 & 94.86 \\
562 & 98.22 & 98.22 & 206.31 & 0.00 & 98.39 \\
579 & 96.20 & 96.20 & 202.10 & 0.00 & 96.37 \\
582 & 96.42 & 96.42 & 202.57 & 0.00 & 96.60 \\
592 & 94.87 & 94.87 & 199.32 & 0.00 & 95.04 \\
593 & 91.52 & 91.52 & 192.34 & 0.00 & 91.70 \\
595 & 89.81 & 89.81 & 188.76 & 0.00 & 89.98 \\
596 & 86.82 & 86.82 & 182.53 & 0.00 & 87.00 \\
597 & 84.65 & 84.65 & 178.00 & 0.00 & 84.83 \\
598 & 87.19 & 87.19 & 183.30 & 0.00 & 87.37 \\
599 & 92.39 & 92.39 & 194.15 & 0.00 & 92.56 \\
600 & 94.25 & 94.25 & 198.04 & 0.00 & 94.43 \\
\hline
\end{tabular}


Table 8 ... PLENUM2 for Test C

\begin{tabular}{|c|c|c|c|c|c|}
\hline ماO & $\begin{array}{l}\text { Measured } \\
\text { Pressure } \\
\text { Inside USH } \\
\text { (psig) } \\
\end{array}$ & $\begin{array}{c}\text { Corrected } \\
\text { Pressure } \\
\text { Outside USH } \\
\text { (psig) }\end{array}$ & $\begin{array}{l}\text { Corrected } \\
\text { Head Outside } \\
\text { USH } \\
(f t)\end{array}$ & $\begin{array}{l}\text { Calculated } \\
\text { Assembly } \\
\text { Flow } \\
\text { (gpm) } \\
\end{array}$ & $\begin{array}{c}\text { Adjusted } \\
\text { Plenum C.L } \\
\text { Pressure } \\
\text { (psig) } \\
\end{array}$ \\
\hline 1 & 71.94 & 73.44 & 151.34 & 226.43 & 73.61 \\
\hline 6 & 68.69 & 73.04 & 144.56 & 394.15 & 73.22 \\
\hline 15 & 71.49 & 72.99 & 150.42 & 225.70 & 73.16 \\
\hline 26 & 68.87 & 73.24 & 144.95 & 394.69 & 73.42 \\
\hline 34 & 68.52 & 72.86 & 144.21 & 393.65 & 73.04 \\
\hline 47 & 70.92 & 72.41 & 149.23 & 224.76 & 72.58 \\
\hline 59 & 69.19 & 73.58 & 145.61 & 395.61 & 73.75 \\
\hline 71 & 71.54 & 73.03 & 150.52 & 225.78 & 73.21 \\
\hline 83 & 70.56 & 72.03 & 148.47 & 224.16 & 72.21 \\
\hline 106 & 66.96 & 71.21 & 140.97 & 389.07 & 71.39 \\
\hline 110 & 71.32 & 75.84 & 150.05 & 401.78 & 76.01 \\
\hline 115 & 76.24 & 77.83 & 160.31 & 233.39 & 78.00 \\
\hline 124 & 67.96 & 72.27 & 143.05 & 392.01 & 72.45 \\
\hline 129 & 71.35 & 72.84 & 150.11 & 225.46 & 73.01 \\
\hline 135 & 71.00 & 72.49 & 149.40 & 224.90 & 72.66 \\
\hline 148 & 69.86 & 74.29 & 147.02 & 397.58 & 74.47 \\
\hline 161 & 73.71 & 75.25 & 155.05 & 229.33 & 75.43 \\
\hline 177 & 71.17 & 72.66 & 149.75 & 225.17 & 72.83 \\
\hline 182 & 67.76 & 72.06 & 142.64 & 391.43 & 72.24 \\
\hline 198 & 71.58 & 76.12 & 150.61 & 402.55 & 76.30 \\
\hline 210 & 66.25 & 70.45 & 139.47 & 386.93 & 70.63 \\
\hline 214 & 67.10 & 71.36 & 141.26 & 389.48 & 71.54 \\
\hline 218 & 73.71 & 78.39 & 155.05 & 408.63 & 78.56 \\
\hline 221 & 73.76 & 75.30 & 155.15 & 229.41 & 75.48 \\
\hline 223 & 82.56 & 83.78 & 173.49 & 203.16 & 83.95 \\
\hline 230 & 78.64 & 82.74 & 165.33 & 381.53 & 82.91 \\
\hline 236 & 75.10 & 79.02 & 157.95 & 372.70 & 79.19 \\
\hline 238 & 68.12 & 72.44 & 143.38 & 392.48 & 72.62 \\
\hline 243 & 72.14 & 73.65 & 151.77 & 226.77 & 73.83 \\
\hline 248 & 67.98 & 71.52 & 143.08 & 354.29 & 71.70 \\
\hline 263 & 74.11 & 75.66 & 155.87 & 229.97 & 75.83 \\
\hline 280 & 78.15 & 82.21 & 164.29 & 380.31 & 82.39 \\
\hline 295 & 71.84 & 73.34 & 151.14 & 226.27 & 73.51 \\
\hline 313 & 77.10 & 78.71 & 162.11 & 234.76 & 78.88 \\
\hline 354 & 68.47 & 72.04 & 144.11 & 355.59 & 72.22 \\
\hline 358 & 68.27 & 72.60 & 143.69 & 392.92 & 72.77 \\
\hline 360 & 69.82 & 73.47 & 146.94 & 359.15 & 73.64 \\
\hline 361 & 73.67 & 77.09 & 154.95 & 347.82 & 77.26 \\
\hline
\end{tabular}


Table 8 ... PLENUM2 for Test C

\begin{tabular}{|c|c|c|c|c|c|}
\hline OLC & $\begin{array}{l}\text { Measured } \\
\text { Pressure } \\
\text { Inside USH } \\
\text { (psig) }\end{array}$ & $\begin{array}{l}\text { Corrected } \\
\text { Pressure } \\
\text { Outside USH } \\
\text { (psig) }\end{array}$ & $\begin{array}{l}\text { Corrected } \\
\text { Head Outside } \\
\text { USH } \\
\text { (ft) }\end{array}$ & $\begin{array}{l}\text { Calculated } \\
\text { Assembly } \\
\text { Flow } \\
\text { (gpm) }\end{array}$ & $\begin{array}{l}\text { Adjusted } \\
\text { Plenum C-L } \\
\text { Pressure } \\
\text { (psig) }\end{array}$ \\
\hline 363 & 83.36 & 84.15 & 175.16 & 162.64 & 84.33 \\
\hline 367 & 84.31 & 86.10 & 177.15 & 247.94 & 86.28 \\
\hline 372 & 84.81 & 86.07 & 178.20 & 205.99 & 86.24 \\
\hline 373 & 89.69 & 90.84 & 188.37 & 197.05 & 91.02 \\
\hline 377 & 87.22 & 87.65 & 183.21 & 118.29 & 87.82 \\
\hline 382 & 70.22 & 73.49 & 147.77 & 339.49 & 73.66 \\
\hline 406 & 85.80 & 86.62 & 180.25 & 165.04 & 86.79 \\
\hline 432 & 70.69 & 73.98 & 148.74 & 340.63 & 74.15 \\
\hline 450 & 81.95 & 85.75 & 172.22 & 367.13 & 85.92 \\
\hline 471 & 75.49 & 76.21 & 158.75 & 154.65 & 76.39 \\
\hline 472 & 68.37 & 71.55 & 143.90 & 334.91 & 71.72 \\
\hline 475 & 80.34 & 80.73 & 168.86 & 113.50 & 80.91 \\
\hline 482 & 91.09 & 91.09 & 191.30 & 0.00 & 91.27 \\
\hline 484 & 91.71 & 91.71 & 192.57 & 0.00 & 91.88 \\
\hline 486 & 93.71 & 93.71 & 196.76 & 0.00 & 93.89 \\
\hline 487 & 87.80 & 87.80 & 184.43 & 0.00 & 87.98 \\
\hline 488 & 89.63 & 89.63 & 188.24 & 0.00 & 89.80 \\
\hline 490 & 94.48 & 94.48 & 198.36 & 0.00 & 94.65 \\
\hline 491 & 90.86 & 91.31 & 190.81 & 120.74 & 91.48 \\
\hline 492 & 94.51 & 94.51 & 198.41 & 0.00 & 94.68 \\
\hline 493 & 92.68 & 92.68 & 194.60 & 0.00 & 92.85 \\
\hline 494 & 94.57 & 94.57 & 198.54 & 0.00 & 94.74 \\
\hline 495 & 93.62 & 93.62 & 196.55 & 0.00 & 93.79 \\
\hline 496 & 89.81 & 89.81 & 188.62 & 0.00 & 89.99 \\
\hline 497 & 93.75 & 93.75 & 196.82 & 0.00 & 93.92 \\
\hline 498 & 93.55 & 93.55 & 196.41 & 0.00 & 93.72 \\
\hline 499 & 90.39 & 90.39 & 189.83 & 0.00 & 90.57 \\
\hline 500 & 88.25 & 88.25 & 185.36 & 0.00 & 88.42 \\
\hline 502 & 90.80 & 90.80 & 190.69 & 0.00 & 90.98 \\
\hline 504 & 89.21 & 89.21 & 187.38 & 0.00 & 89.39 \\
\hline 506 & 86.08 & 86.08 & 180.83 & 0.00 & 86.25 \\
\hline 507 & 76.70 & 77.69 & 161.27 & 182.25 & 77.87 \\
\hline 508 & 86.72 & 86.72 & 182.17 & 0.00 & 86.89 \\
\hline 509 & 79.92 & 80.31 & 167.98 & 113.20 & 80.49 \\
\hline 510 & 86.66 & 86.66 & 182.05 & 0.00 & 86.84 \\
\hline 512 & 89.52 & 89.52 & 188.01 & 0.00 & 89.69 \\
\hline 520 & 91.51 & 91.51 & 192.16 & 0.00 & 91.68 \\
\hline 524 & 93.53 & 93.53 & 196.37 & 0.00 & 93.70 \\
\hline
\end{tabular}


Table 8 ... PLENUM2 for Test $C$

\begin{tabular}{|c|c|c|c|c|c|}
\hline CL & $\begin{array}{l}\text { Measured } \\
\text { Pressure } \\
\text { Inside USH } \\
\text { (psig) } \\
\end{array}$ & $\begin{array}{c}\text { Corrected } \\
\text { Pressure } \\
\text { Outside USH } \\
\text { (psig) }\end{array}$ & $\begin{array}{l}\text { Corrected } \\
\text { Head Outside } \\
\text { USH } \\
\text { (ft) }\end{array}$ & $\begin{array}{l}\text { Calculated } \\
\text { Assembly } \\
\text { Flow } \\
\text { (gpm) } \\
\end{array}$ & $\begin{array}{l}\text { Adjusted } \\
\text { Plenum C-L } \\
\text { Pressure } \\
\text { (psig) } \\
\end{array}$ \\
\hline 539 & 91.03 & 91.03 & 191.16 & 0.00 & 91.20 \\
\hline 542 & 89.61 & 89.61 & 188.20 & 0.00 & 89.79 \\
\hline 559 & 90.65 & 90.65 & 190.36 & 0.00 & 90.82 \\
\hline 562 & 93.58 & 93.58 & 196.48 & 0.00 & 93.75 \\
\hline 579 & 91.64 & 91.64 & 192.44 & 0.00 & 91.82 \\
\hline 582 & 91.62 & 91.62 & 192.40 & 0.00 & 91.80 \\
\hline 592 & 90.19 & 90.19 & 189.42 & 0.00 & 90.37 \\
\hline 593 & 87.09 & 87.09 & 182.93 & 0.00 & 87.26 \\
\hline 595 & 85.37 & 85.37 & 179.37 & 0.00 & 85.55 \\
\hline 596 & 83.01 & 83.01 & 174.43 & 0.00 & 83.18 \\
\hline 597 & 80.91 & 80.91 & 170.05 & 0.00 & 81.08 \\
\hline 598 & 83.26 & 83.26 & 174.95 & 0.00 & 83.43 \\
\hline 599 & 88.64 & 88.64 & 186.17 & 0.00 & 88.81 \\
\hline 600 & 89.82 & 89.82 & 188.64 & 0.00 & 90.00 \\
\hline
\end{tabular}


Table 9 ... PLENUM2 for Test D

\begin{tabular}{|c|c|c|c|c|c|}
\hline OLC & $\begin{array}{l}\text { Measured } \\
\text { Pressure } \\
\text { Inside USH } \\
\text { (psig) }\end{array}$ & $\begin{array}{l}\text { Corrected } \\
\text { Pressure } \\
\text { Outside USH } \\
\text { (psig) }\end{array}$ & $\begin{array}{l}\text { Corrected } \\
\text { Head Outside } \\
\text { USH } \\
\text { (ft) }\end{array}$ & $\begin{array}{l}\text { Calculated } \\
\text { Assembly } \\
\text { Flow } \\
\text { (gpm) }\end{array}$ & $\begin{array}{l}\text { Adjusted } \\
\text { Plenum C-L } \\
\text { Pressure } \\
\text { (psig) }\end{array}$ \\
\hline 1 & 49.11 & 50.14 & 103.74 & 185.63 & 50.32 \\
\hline 6 & 46.81 & 49.80 & 98.93 & 324.13 & 49.97 \\
\hline 15 & 49.82 & 50.86 & 105.20 & 187.00 & 51.03 \\
\hline 26 & 47.64 & 50.68 & 100.67 & 327.06 & 50.86 \\
\hline 34 & 46.50 & 49.47 & 98.28 & 323.04 & 49.64 \\
\hline 47 & 49.38 & 50.41 & 104.30 & 186.15 & 50.59 \\
\hline 59 & 46.35 & 49.32 & 97.98 & 322.54 & 49.49 \\
\hline 71 & 51.16 & 52.23 & 108.00 & 189.60 & 52.40 \\
\hline 83 & 48.67 & 49.69 & 102.82 & 184.76 & 49.87 \\
\hline 106 & 47.32 & 50.35 & 100.01 & 325.96 & 50.52 \\
\hline 110 & 47.64 & 50.68 & 100.66 & 327.06 & 50.86 \\
\hline 115 & 48.28 & 49.29 & 102.00 & 183.99 & 49.47 \\
\hline 124 & 44.88 & 47.75 & 94.91 & 317.28 & 47.92 \\
\hline 129 & 48.89 & 49.92 & 103.28 & 185.19 & 50.09 \\
\hline 135 & 50.51 & 51.57 & 106.65 & 188.35 & 51.74 \\
\hline 148 & 51.68 & 54.98 & 109.10 & 340.91 & 55.15 \\
\hline 161 & 53.79 & 54.91 & 113.49 & 194.61 & 55.09 \\
\hline 177 & 50.86 & 51.92 & 107.37 & 189.02 & 52.09 \\
\hline 182 & 46.32 & 49.28 & 97.92 & 322.43 & 49.46 \\
\hline 198 & 51.77 & 55.07 & 109.27 & 341.19 & 55.24 \\
\hline 210 & 47.48 & 50.51 & 100.33 & 326.51 & 50.69 \\
\hline 214 & 47.08 & 50.08 & 99.49 & 325.09 & 50.26 \\
\hline 218 & 48.07 & 51.14 & 101.57 & 328.57 & 51.32 \\
\hline 221 & 48.61 & 49.63 & 102.69 & 184.64 & 49.80 \\
\hline 223 & 50.23 & 50.97 & 106.06 & 157.40 & 51.15 \\
\hline 230 & 47.20 & 49.69 & 99.75 & 294.46 & 49.86 \\
\hline 236 & 47.47 & 49.97 & 100.32 & 295.31 & 50.15 \\
\hline 238 & 43.28 & 46.05 & 91.58 & 311.50 & 46.23 \\
\hline 243 & 50.24 & 51.29 & 106.09 & 187.83 & 51.47 \\
\hline 248 & 48.12 & 50.65 & 101.66 & 297.33 & 50.82 \\
\hline 263 & 55.12 & 56.27 & 116.26 & 197.10 & 56.45 \\
\hline 280 & 59.36 & 62.47 & 125.10 & 330.79 & 62.64 \\
\hline 295 & 51.60 & 52.68 & 108.93 & 190.46 & 52.86 \\
\hline 313 & 54.93 & 56.08 & 115.88 & 196.76 & 56.26 \\
\hline 354 & 48.56 & 51.11 & 102.58 & 298.71 & 51.29 \\
\hline 358 & 46.76 & 49.74 & 98.82 & 323.96 & 49.92 \\
\hline 360 & 46.83 & 49.30 & 98.98 & 293.29 & 49.48 \\
\hline 361 & 47.40 & 49.63 & 100.16 & 278.26 & 49.80 \\
\hline
\end{tabular}


Table 9 ... PLENUM2 for Test D

\begin{tabular}{|c|c|c|c|c|c|}
\hline OLC & $\begin{array}{l}\text { Measured } \\
\text { Pressure } \\
\text { Inside USH } \\
\text { (psig) } \\
\end{array}$ & $\begin{array}{l}\text { Corrected } \\
\text { Pressure } \\
\text { Outside USH } \\
\text { (psig) }\end{array}$ & $\begin{array}{c}\text { Corrected } \\
\text { Head Outside } \\
\text { USH } \\
\text { (ft) }\end{array}$ & $\begin{array}{l}\text { Calculated } \\
\text { Assembly } \\
\text { Flow } \\
\text { (gpm) } \\
\end{array}$ & $\begin{array}{l}\text { Adjusted } \\
\text { Plenum C-L } \\
\text { Pressure } \\
\text { (psig) } \\
\end{array}$ \\
\hline 363 & 50.81 & 51.30 & 107.28 & 126.53 & 51.48 \\
\hline 367 & 49.93 & 51.02 & 105.45 & 190.78 & 51.19 \\
\hline 372 & 49.72 & 50.46 & 105.00 & 156.58 & 50.63 \\
\hline 373 & 49.39 & 50.04 & 104.32 & 146.38 & 50.22 \\
\hline 377 & 53.46 & 53.72 & 112.80 & 92.53 & 53.90 \\
\hline 382 & 49.03 & 51.34 & 103.57 & 283.08 & 51.51 \\
\hline 406 & 66.56 & 67.20 & 140.12 & 145.07 & 67.37 \\
\hline 432 & 51.84 & 54.27 & 109.42 & 291.13 & 54.44 \\
\hline 450 & 60.53 & 63.36 & 127.54 & 314.87 & 63.53 \\
\hline 471 & 50.92 & 51.42 & 107.51 & 126.67 & 51.59 \\
\hline 472 & 49.15 & 51.46 & 103.82 & 283.42 & 51.64 \\
\hline 475 & 50.84 & 51.09 & 107.34 & 90.23 & 51.26 \\
\hline 482 & 52.08 & 52.08 & 109.92 & 0.00 & 52.25 \\
\hline 484 & 51.95 & 51.95 & 109.65 & 0.00 & 52.12 \\
\hline 486 & 51.32 & 51.32 & 108.34 & 0.00 & 51.50 \\
\hline 487 & - & & - & - & $\cdot$ \\
\hline 488 & 51.52 & 51.52 & 108.77 & 0.00 & 51.70 \\
\hline 490 & 50.97 & 50.97 & 107.61 & 0.00 & 51.14 \\
\hline 491 & 50.34 & 50.59 & 106.30 & 89.79 & 50.76 \\
\hline 492 & 52.95 & 52.95 & 111.75 & 0.00 & 53.13 \\
\hline 493 & 50.91 & 50.91 & 107.48 & 0.00 & 51.08 \\
\hline 494 & 52.43 & 52.43 & 110.65 & 0.00 & 52.60 \\
\hline 495 & 53.66 & 53.66 & 113.23 & 0.00 & 53.84 \\
\hline 496 & 50.82 & 50.82 & 107.31 & 0.00 & 51.00 \\
\hline 497 & 53.12 & 53.12 & 112.09 & 0.00 & 53.29 \\
\hline 498 & 60.86 & 60.86 & 128.23 & 0.00 & 61.03 \\
\hline 499 & 64.17 & 64.17 & 135.14 & 0.00 & 64.34 \\
\hline 500 & 63.36 & 63.36 & 133.45 & 0.00 & 63.54 \\
\hline 502 & 68.35 & 68.35 & 143.85 & 0.00 & 68.52 \\
\hline 504 & 71.15 & 71.15 & 149.69 & 0.00 & 71.32 \\
\hline 506 & 69.08 & 69.08 & 145.38 & 0.00 & 69.26 \\
\hline 507 & 58.62 & 59.39 & 123.56 & 159.39 & 59.56 \\
\hline 508 & 67.43 & 67.43 & 141.94 & 0.00 & 67.61 \\
\hline 509 & 58.57 & 58.85 & 123.45 & 96.85 & 59.03 \\
\hline 510 & 69.50 & 69.50 & 146.26 & 0.00 & 69.68 \\
\hline 512 & 66.13 & 66.13 & 139.22 & 0.00 & 66.30 \\
\hline 520 & 69.00 & 69.00 & 145.20 & 0.00 & 69.17 \\
\hline 524 & 73.80 & 73.80 & 155.22 & 0.00 & 73.98 \\
\hline
\end{tabular}


Table 9 ... PLENUM2 for Test $D$

\begin{tabular}{|cccccc|} 
OLC & $\begin{array}{c}\text { Measured } \\
\text { Pressure } \\
\text { Inside USH } \\
\text { (psig) }\end{array}$ & $\begin{array}{c}\text { Corrected } \\
\text { Pressure } \\
\text { Outside USH } \\
\text { (psig) }\end{array}$ & $\begin{array}{c}\text { Corrected } \\
\text { Head Outside } \\
\text { USH } \\
\text { (ft) }\end{array}$ & $\begin{array}{c}\text { Calculated } \\
\text { Assembly } \\
\text { Flow } \\
\text { (gpm) }\end{array}$ & $\begin{array}{c}\text { Adjusted } \\
\text { Plenum C-L } \\
\text { Pressure } \\
\text { (psig) }\end{array}$ \\
\hline 539 & 71.95 & 71.35 & 151.37 & 0.00 & 72.13 \\
542 & 70.44 & 70.44 & 148.21 & 0.00 & 70.61 \\
559 & 71.18 & 71.18 & 149.76 & 0.00 & 71.36 \\
562 & 73.55 & 73.55 & 154.70 & 0.00 & 73.73 \\
579 & 71.30 & 71.30 & 150.01 & 0.00 & 71.48 \\
582 & 53.58 & 63.58 & 133.91 & 0.00 & 63.76 \\
592 & 45.27 & 45.27 & 95.72 & 0.00 & 45.44 \\
593 & 52.94 & 52.94 & 111.71 & 0.00 & 53.11 \\
595 & 51.66 & 51.66 & 109.06 & 0.00 & 51.84 \\
596 & 52.04 & 52.04 & 109.84 & 0.00 & 52.21 \\
597 & 51.27 & 51.27 & 108.25 & 0.00 & 51.45 \\
598 & 51.77 & 51.77 & 109.29 & 0.00 & 51.95 \\
599 & 51.63 & 51.63 & 108.99 & 0.00 & 51.80 \\
600 & 51.79 & 51.79 & 109.32 & 0.00 & 51.96 \\
\hline
\end{tabular}


WSRC-TR-92-134

Task 91-033-1

DQ Summary for 1985 L-Area AC Flow Tests

Table 10 ... PLENUM2 for Test E

\begin{tabular}{|c|c|c|c|c|c|}
\hline OLC & $\begin{array}{l}\text { Measured } \\
\text { Pressure } \\
\text { Inside USH } \\
\text { (psig) } \\
\end{array}$ & $\begin{array}{l}\text { Corrected } \\
\text { Pressure } \\
\text { Outside USH } \\
\text { (psig) }\end{array}$ & $\begin{array}{l}\text { Corrected } \\
\text { Head Outside } \\
\text { USH } \\
\text { (ft) }\end{array}$ & $\begin{array}{l}\text { Calculated } \\
\text { Assembly } \\
\text { Flow } \\
\text { (gpm) } \\
\end{array}$ & $\begin{array}{l}\text { Adjusted } \\
\text { Plenum C.L } \\
\text { Pressure } \\
\text { (psig) }\end{array}$ \\
\hline 1 & 48.65 & 49.67 & 102.78 & 184.72 & 49.84 \\
\hline 6 & 46.84 & 49.84 & 99.01 & 324.27 & 50.01 \\
\hline 15 & $48: 80$ & 49.82 & 103.09 & 185.02 & 50.00 \\
\hline 26 & 46.81 & 49.80 & 98.94 & 324.16 & 49.98 \\
\hline 34 & 47.81 & 50.87 & 101.02 & 327.66 & 51.04 \\
\hline 47 & 48.63 & 49.65 & 102.74 & 184.68 & 49.83 \\
\hline 59 & 47.41 & 50.43 & 100.18 & 326.25 & 50.61 \\
\hline 71 & 48.20 & 49.21 & 101.83 & 183.82 & 49.38 \\
\hline 83 & 49.50 & 50.53 & 104.54 & 186.38 & 50.71 \\
\hline 106 & 46.10 & 49.05 & 97.46 & 321.64 & 49.22 \\
\hline 110 & 45.49 & 48.40 & 96.18 & 319.46 & 48.57 \\
\hline 115 & 48.35 & 49.36 & 102.15 & 184.12 & 49.54 \\
\hline 124 & 46.88 & 49.88 & 99.08 & 324.40 & 50.05 \\
\hline 129 & 48.71 & 49.73 & 102.89 & 184.83 & 49.90 \\
\hline 135 & 49.30 & 50.33 & 104.12 & 185.99 & 50.50 \\
\hline 148 & 47.47 & 50.50 & 100.32 & 326.47 & 50.68 \\
\hline 161 & 51.50 & 52.58 & 108.71 & 190.26 & 52.75 \\
\hline 177 & 52.23 & 53.32 & 110.24 & 191.66 & 53.50 \\
\hline 182 & 49.49 & 52.65 & 104.53 & 333.47 & 52.83 \\
\hline 198 & 53.74 & 57.17 & 113.39 & 347.76 & 57.34 \\
\hline 210 & 46.41 & 49.37 & 98.09 & 322.73 & 49.55 \\
\hline 214 & 45.79 & 48.71 & 96.80 & 320.52 & 48.89 \\
\hline 218 & 44.64 & 47.50 & 94.42 & 316.43 & 47.67 \\
\hline 221 & 49.74 & 50.78 & 105.05 & 186.86 & 50.96 \\
\hline 223 & 49.64 & 50.38 & 104.84 & 156.46 & 50.56 \\
\hline 230 & 48.92 & 51.50 & 103.34 & 299.84 & 51.67 \\
\hline 236 & 48.46 & 51.01 & 102.37 & 298.40 & 51.18 \\
\hline 238 & 47.35 & 50.37 & 100.05 & 326.03 & 50.54 \\
\hline 243 & 48.63 & 49.65 & 102.73 & 184.68 & 49.82 \\
\hline 248 & 47.25 & 49.74 & 99.85 & 294.60 & 49.91 \\
\hline 263 & 52.81 & 53.91 & 111.44 & 192.75 & 54.08 \\
\hline 280 & 56.90 & 59.89 & 119.99 & 323.71 & 60.06 \\
\hline 295 & 50.67 & 51.73 & 106.98 & 188.66 & 51.90 \\
\hline 313 & 58.17 & 59.38 & 122.62 & 202.69 & 59.56 \\
\hline 354 & 47.98 & 50.51 & 101.38 & 296.91 & 50.68 \\
\hline 358 & 46.73 & 49.72 & 98.78 & 323.88 & 49.89 \\
\hline 360 & 47.69 & 50.20 & 100.76 & 295.98 & 50.37 \\
\hline 361 & 50.36 & 52.72 & 106.33 & 286.91 & 52.90 \\
\hline
\end{tabular}


Table 10 ... PLENUM2 for Test E

\begin{tabular}{|c|c|c|c|c|c|}
\hline OLC & $\begin{array}{l}\text { Measured } \\
\text { Pressure } \\
\text { Inside USH } \\
\text { (psig) } \\
\end{array}$ & $\begin{array}{c}\text { Corrected } \\
\text { Pressure } \\
\text { Outside USH } \\
\text { (psig) }\end{array}$ & $\begin{array}{l}\text { Corrected } \\
\text { Head Outside } \\
\text { USH } \\
\text { (ft) }\end{array}$ & $\begin{array}{l}\text { Calculated } \\
\text { Assembly } \\
\text { Flow } \\
\text { (gpm) } \\
\end{array}$ & $\begin{array}{l}\text { Adjusted } \\
\text { Plenum C-L } \\
\text { Pressure } \\
\text { (psig) } \\
\end{array}$ \\
\hline 363 & 54.75 & 55.28 & 115.50 & 131.41 & 55.46 \\
\hline 367 & 48.54 & 49.60 & 102.55 & 188.12 & 49.77 \\
\hline 372 & 49.70 & 50.45 & 104.97 & 156.56 & 50.62 \\
\hline 373 & 49.62 & 50.27 & 104.80 & 146.71 & 50.45 \\
\hline 377 & 51.57 & 51.83 & 108.87 & 90.88 & 52.00 \\
\hline 382 & 46.03 & 48.20 & 97.32 & 274.20 & 48.38 \\
\hline 406 & 64.38 & 65.00 & 135.58 & 142.65 & 65.18 \\
\hline 432 & 52.73 & 55.20 & 111.28 & 293.65 & 55.38 \\
\hline 450 & 63.26 & 66.22 & 133.25 & 321.99 & 66.39 \\
\hline 471 & 55.50 & 56.03 & 117.05 & 132.31 & 56.21 \\
\hline 472 & 48.90 & 51.20 & 103.29 & 282.67 & 51.37 \\
\hline 475 & 57.85 & 58.14 & 121.96 & 96.26 & 58.31 \\
\hline 482 & 66.75 & 66.75 & 140.52 & 0.00 & 66.93 \\
\hline 484 & 64.09 & 64.09 & 134.97 & 0.00 & 64.26 \\
\hline 486 & 62.09 & 62.09 & 130.80 & 0.00 & 62.26 \\
\hline 487 & - & - & - & • & $\cdot$ \\
\hline 488 & 51.32 & 51.32 & 108.33 & 0.00 & 51.49 \\
\hline 490 & 53.77 & 53.77 & 113.45 & 0.00 & 53.95 \\
\hline 491 & 50.50 & 50.74 & 106.62 & 89.92 & 50.92 \\
\hline 492 & 49.99 & 49.99 & 105.56 & 0.00 & 50.16 \\
\hline 493 & 50.55 & 50.55 & 106.74 & 0.00 & 50.73 \\
\hline 494 & 51.80 & 51.80 & 109.34 & 0.00 & 51.97 \\
\hline 495 & 51.06 & 51.06 & 107.79 & 0.00 & 51.23 \\
\hline 496 & 51.62 & 51.62 & 108.96 & 0.00 & 51.79 \\
\hline 497 & 51.83 & 51.83 & 109.40 & 0.00 & 52.01 \\
\hline 498 & 51.70 & 51.70 & 109.13 & 0.00 & 51.88 \\
\hline 499 & 52.30 & 52.30 & 110.37 & 0.00 & 52.47 \\
\hline 500 & 52.11 & 52.11 & 109.98 & 0.00 & 52.28 \\
\hline 502 & 51.95 & 51.95 & 109.65 & 0.00 & 52.12 \\
\hline 504 & 51.91 & 51.91 & 109.58 & 0.00 & 52.09 \\
\hline 506 & 52.37 & 52.37 & 110.53 & 0.00 & 52.55 \\
\hline 507 & 49.68 & 50.33 & 104.91 & 146.80 & 50.51 \\
\hline 508 & 52.16 & 52.16 & 110.09 & 0.00 & 52.33 \\
\hline 509 & 50.81 & 51.06 & 107.27 & 90.20 & 51.23 \\
\hline 510 & 52.32 & 52.32 & 110.43 & 0.00 & 52.49 \\
\hline 512 & 48.37 & 48.37 & 102.19 & 0.00 & 48.55 \\
\hline 520 & 65.85 & 65.85 & 138.63 & 0.00 & 66.02 \\
\hline 524 & 72.12 & 72.12 & 151.72 & 0.00 & 72.30 \\
\hline
\end{tabular}


Table 10 ... PLENUM2 for Test E

\begin{tabular}{|cccccc|}
\multicolumn{1}{c}{$\begin{array}{c}\text { Measured } \\
\text { Pressure } \\
\text { Inside USH } \\
\text { OLC }\end{array}$} & $\begin{array}{c}\text { Corrected } \\
\text { Pressure } \\
\text { Outside USH } \\
\text { (psig) }\end{array}$ & $\begin{array}{c}\text { Corrected } \\
\text { Head Outside } \\
\text { LSH } \\
\text { (fi) }\end{array}$ & $\begin{array}{c}\text { Calculated } \\
\text { Assembly } \\
\text { Flow } \\
\text { (gpm) }\end{array}$ & $\begin{array}{c}\text { Adjusted } \\
\text { Plenum C.L } \\
\text { Pressure } \\
\text { (psig) }\end{array}$ \\
\hline 539 & 71.05 & 71.05 & 149.47 & 0.00 & 71.22 \\
542 & 70.87 & 70.87 & 149.10 & 0.00 & 71.04 \\
559 & 70.21 & 70.21 & 147.72 & 0.00 & 70.38 \\
562 & 74.60 & 74.60 & 156.90 & 0.00 & 74.78 \\
579 & 73.50 & 73.50 & 154.59 & 0.00 & 73.67 \\
582 & 69.14 & 69.14 & 145.49 & 0.00 & 69.31 \\
592 & 62.00 & 62.00 & 130.62 & 0.00 & 62.18 \\
593 & 65.08 & 65.08 & 137.04 & 0.00 & 65.26 \\
595 & 69.27 & 69.27 & 145.77 & 0.00 & 69.45 \\
596 & 66.52 & 66.52 & 140.05 & 0.00 & 66.70 \\
597 & 66.46 & 66.46 & 139.92 & 0.00 & 66.64 \\
598 & 66.61 & 66.61 & 140.22 & 0.00 & 66.78 \\
599 & 69.17 & 69.17 & 145.57 & 0.00 & 69.35 \\
600 & 69.54 & 69.54 & 146.33 & 0.00 & 69.71 \\
\hline
\end{tabular}


Table 11 ... PLENUM2 for Test $F$

\begin{tabular}{|c|c|c|c|c|c|}
\hline OLC & $\begin{array}{l}\text { Measured } \\
\text { Pressure } \\
\text { Inside USH } \\
\text { (psig) } \\
\end{array}$ & $\begin{array}{l}\text { Corrected } \\
\text { Pressure } \\
\text { Outside USH } \\
\text { (psig) } \\
\end{array}$ & $\begin{array}{l}\text { Corrected } \\
\text { Head Outside } \\
\text { USH } \\
\text { (ft) }\end{array}$ & $\begin{array}{l}\text { Calculated } \\
\text { Assembly } \\
\text { Flow } \\
\text { (gpm) }\end{array}$ & $\begin{array}{l}\text { Adjusted } \\
\text { Plenum C-L } \\
\text { Pressure } \\
\text { (psig) } \\
\end{array}$ \\
\hline 1 & 26.78 & 27.34 & 57.18 & 135.67 & 27.52 \\
\hline 6 & 25.74 & 27.42 & 55.01 & 239.52 & 27.59 \\
\hline 15 & 26.55 & 27.11 & 56.70 & 135.07 & 27.28 \\
\hline 26 & 25.54 & 27.20 & 54.59 & 238.57 & 27.38 \\
\hline 34 & 25.50 & 27.16 & 54.52 & 238.41 & 27.34 \\
\hline 47 & 26.53 & 27.09 & 56.66 & 135.03 & 27.27 \\
\hline 59 & 25.85 & 27.53 & 55.24 & 240.04 & 27.71 \\
\hline 71 & 26.69 & 27.25 & 56.99 & 135.44 & 27.43 \\
\hline 83 & 26.47 & 27.03 & 56.53 & 134.86 & 27.20 \\
\hline 106 & 25.18 & 26.82 & 53.84 & 236.87 & 26.99 \\
\hline 110 & 26.68 & 28.42 & 56.98 & 243.90 & 28.59 \\
\hline 115 & 28.22 & 28.81 & 60.17 & 139.37 & 28.98 \\
\hline 124 & 25.08 & 26.71 & 53.63 & 236.39 & 26.88 \\
\hline 129 & 26.48 & 27.04 & 56.56 & 134.89 & 27.21 \\
\hline 135 & 26.88 & 27.44 & 57.39 & 135.93 & 27.62 \\
\hline 148 & 26.68 & 28.41 & 56.97 & 243.89 & 28.59 \\
\hline 161 & 27.39 & 27.97 & 58.46 & 137.26 & 28.14 \\
\hline 177 & 26.47 & 27.03 & 56.54 & 134.87 & 27.20 \\
\hline 182 & 25.51 & 27.17 & 54.54 & 238.45 & 27.35 \\
\hline 198 & 26.52 & 28.24 & 56.63 & 243.12 & 28.41 \\
\hline 210 & 25.34 & 26.99 & 54.18 & 237.64 & 27.16 \\
\hline 214 & 25.09 & 26.72 & 53.65 & 236.45 & 26.90 \\
\hline 218 & 27.93 & 29.74 & 59.59 & 249.59 & 29.92 \\
\hline 221 & 27.46 & 28.04 & 58.59 & 137.43 & 28.21 \\
\hline 223 & 31.11 & 31.57 & 66.20 & 123.27 & 31.75 \\
\hline 230 & 29.03 & 30.58 & 61.87 & 230.49 & 30.76 \\
\hline 236 & 27.59 & 29.07 & 58.87 & 224.69 & 29.25 \\
\hline 238 & 23.95 & 25.51 & 51.27 & 230.97 & 25.68 \\
\hline 243 & 26.94 & 27.50 & 57.50 & 136.08 & 27.68 \\
\hline 248 & 25.40 & 26.76 & 54.29 & 215.55 & 26.94 \\
\hline 263 & 27.63 & 28.21 & 58.95 & 137.87 & 28.39 \\
\hline 280 & 29.85 & 31.45 & 63.58 & 233.75 & 31.62 \\
\hline 295 & 26.55 & 27.11 & 56.69 & 135.06 & 27.28 \\
\hline 313 & 29.02 & 29.63 & 61.85 & 141.39 & 29.80 \\
\hline 354 & 25.47 & 26.84 & 54.44 & 215.85 & 27.01 \\
\hline 358 & 25.26 & 26.90 & 54.00 & 237.25 & 27.08 \\
\hline 360 & 25.25 & 26.61 & 53.99 & 214.93 & 26.79 \\
\hline 361 & 27.76 & 29.10 & 59.23 & 212.71 & 29.27 \\
\hline
\end{tabular}


WSRC-TR-92-134

Task 91-033-1

DQ Summary for 1985 L-Area AC Flow Tests
March 10, 1992

Revision 0

Page 48 of 119

Table 11 ... PLENUM2 for Test $F$

\begin{tabular}{|c|c|c|c|c|c|}
\hline OL & $\begin{array}{l}\text { Measured } \\
\text { Pressure } \\
\text { Inside USH } \\
\text { (psig) } \\
\end{array}$ & $\begin{array}{l}\text { Corrected } \\
\text { Pressure } \\
\text { Outside USH } \\
\text { (psig) }\end{array}$ & $\begin{array}{c}\text { Corrected } \\
\text { Head Outside } \\
\text { USH } \\
\text { (ft) }\end{array}$ & $\begin{array}{l}\text { Calculated } \\
\text { Assembly } \\
\text { Flow } \\
\text { (gpm) }\end{array}$ & $\begin{array}{l}\text { Adjusted } \\
\text { Plenum C-L } \\
\text { Pressure } \\
\text { (psig) } \\
\end{array}$ \\
\hline 363 & 31.23 & 31.53 & 66.45 & 99.00 & 31.70 \\
\hline 367 & 32.38 & 33.09 & 68.85 & 153.82 & 33.27 \\
\hline 372 & 31.95 & 32.43 & 67.96 & 124.95 & 32.60 \\
\hline 373 & 31.66 & 32.08 & 67.35 & 117.46 & 32.26 \\
\hline 377 & 32.76 & 32.91 & 69.64 & 72.48 & 33.09 \\
\hline 382 & 24.64 & 25.83 & 52.71 & 200.38 & 26.00 \\
\hline 406 & 33.21 & 33.54 & 70.60 & 102.12 & 33.71 \\
\hline 432 & 26.57 & 27.85 & 56.75 & 208.11 & 28.03 \\
\hline 450 & 31.48 & 32.99 & 66.99 & 226.54 & 33.16 \\
\hline 471 & 28.08 & 28.35 & 59.88 & 93.86 & 28.52 \\
\hline 472 & 25.90 & 27.14 & 55.33 & 205.43 & 27.32 \\
\hline 475 & 29.24 & 29.38 & 62.31 & 68.51 & 29.56 \\
\hline 482 & 34.41 & 34.41 & 73.09 & 0.00 & 34.59 \\
\hline 484 & 34.01 & 34.01 & 72.26 & 0.00 & 34.19 \\
\hline 486 & 34.03 & 34.03 & 72.29 & 0.00 & 34.20 \\
\hline 487 & 33.24 & 33.24 & 70.65 & 0.00 & 33.41 \\
\hline 488 & 33.78 & 33.78 & 71.77 & 0.00 & 33.95 \\
\hline 490 & 33.77 & 33.77 & 71.76 & 0.00 & 33.95 \\
\hline 491 & 33.20 & 33.36 & 70.56 & 72.96 & 33.53 \\
\hline 492 & 34.50 & 34.50 & 73.27 & 0.00 & 34.67 \\
\hline 493 & 32.96 & 32.96 & 70.06 & 0.00 & 33.13 \\
\hline 494 & 33.25 & 33.25 & 70.68 & 0.00 & 33.43 \\
\hline 495 & 33.72 & 33.72 & 71.66 & 0.00 & 33.90 \\
\hline 496 & 32.29 & 32.29 & 68.67 & 0.00 & 32.46 \\
\hline 497 & 33.54 & 33.54 & 71.29 & 0.00 & 33.72 \\
\hline 498 & $36.3 C$ & 36.30 & 77.03 & 0.00 & 36.47 \\
\hline 499 & 37.08 & 37.08 & 78.66 & 0.00 & 37.26 \\
\hline 500 & 35.34 & 35.34 & 75.03 & 0.00 & 35.51 \\
\hline 502 & 35.91 & 35.91 & 76.22 & 0.00 & 36.08 \\
\hline 504 & 33.35 & 33.35 & 70.88 & 0.00 & 33.52 \\
\hline 506 & 28.16 & 28.16 & 60.06 & 0.00 & 28.33 \\
\hline 507 & 25.92 & 26.27 & 55.38 & 106.45 & 26.44 \\
\hline 508 & 30.23 & 30.23 & 64.37 & 0.00 & 30.41 \\
\hline 509 & 2800 & 28.13 & 59.71 & 67.04 & 28.30 \\
\hline 510 & $28: 3$ & 28.99 & 61.80 & 0.00 & 29.17 \\
\hline 512 & 24.27 & 24.27 & 51.94 & 0.00 & 24.44 \\
\hline 520 & 36.78 & 36.78 & $-: .04$ & 0.00 & 36.95 \\
\hline 524 & 36.12 & 36.12 & 73.66 & 0.00 & 36.29 \\
\hline
\end{tabular}


Table 11 ... PLENUM2 for Test F

\begin{tabular}{|c|c|c|c|c|c|}
\hline عاد & $\begin{array}{l}\text { Measured } \\
\text { F'ressure } \\
\text { !nsida USH } \\
\text { (psig) }\end{array}$ & $\begin{array}{l}\text { Corrected } \\
\text { Pressure } \\
\text { Outside USH } \\
\text { (psig) }\end{array}$ & $\begin{array}{l}\text { Corrected } \\
\text { Head Outside } \\
\text { USH } \\
(f t)\end{array}$ & $\begin{array}{l}\text { Calculated } \\
\text { Assembly } \\
\text { Flow } \\
\text { (gpm) }\end{array}$ & $\begin{array}{l}\text { Adjusted } \\
\text { Plenum C-L } \\
\text { Pressure } \\
\text { (psig) }\end{array}$ \\
\hline 539 & 38.30 & 38.30 & 81.21 & 0.00 & 38.48 \\
\hline 542 & 36.48 & 36.48 & 77.41 & 0.00 & 36.65 \\
\hline 559 & 35.97 & 36.97 & 78.42 & 0.00 & 37.14 \\
\hline 562 & 36.72 & 36.72 & 77.91 & 0.00 & 36.89 \\
\hline 579 & 37.69 & 37.69 & 79.93 & 0.00 & 37.86 \\
\hline 582 & 35.45 & 35.45 & 75.27 & 0.00 & 35.63 \\
\hline 592 & 24.94 & 24.94 & 53.34 & 0.00 & 25.12 \\
\hline 593 & 29.47 & 29.47 & 62.78 & 0.00 & 29.64 \\
\hline 595 & 30.53 & 30.53 & 64.99 & 0.00 & 30.70 \\
\hline 596 & 31.28 & 31.28 & 66.57 & 0.00 & 31.46 \\
\hline 597 & 31.98 & 31.98 & 68.03 & 0.00 & 32.16 \\
\hline 598 & 34.59 & 34.59 & 73.47 & 0.00 & $34: 77$ \\
\hline 599 & 35.20 & 35.20 & 74.74 & 0.00 & 35.37 \\
\hline 600 & 34.83 & 34.83 & 73.96 & 0.00 & 35.00 \\
\hline
\end{tabular}


Table 12 ... PLENUM2 for Test G

\begin{tabular}{|c|c|c|c|c|c|}
\hline OLC & $\begin{array}{l}\text { Measured } \\
\text { Pressure } \\
\text { Inside USH } \\
\text { (psig) } \\
\end{array}$ & $\begin{array}{l}\text { Corrected } \\
\text { Pressure } \\
\text { Outside USH } \\
\text { (psig) } \\
\end{array}$ & $\begin{array}{c}\text { Corrected } \\
\text { Head Outside } \\
\text { USH } \\
\text { (ft) }\end{array}$ & $\begin{array}{l}\text { Calculated } \\
\text { Assembly } \\
\text { Flow } \\
\text { (gpm) } \\
\end{array}$ & $\begin{array}{l}\text { Adjusted } \\
\text { Pienum C-L } \\
\text { Pressure } \\
\text { (psig) } \\
\end{array}$ \\
\hline 1 & 46.77 & 47.02 & 98.83 & 182.04 & 47.20 \\
\hline 6 & 43.89 & 46.68 & 94.22 & 317.21 & 46.85 \\
\hline 15 & 45.74 & 46.69 & 98.14 & 181.37 & 46.86 \\
\hline 26 & 44.05 & 46.85 & 94.56 & 317.80 & 47.02 \\
\hline 34 & 43.84 & 46.63 & 94.11 & 317.03 & 46.80 \\
\hline 47 & 45.39 & 46.33 & 97.40 & 180.65 & 46.51 \\
\hline 59 & 44.34 & 47.16 & 95.16 & 318.85 & 47.33 \\
\hline 71 & 45.84 & 46.79 & 98.34 & 181.56 & 46.96 \\
\hline 83 & 45.16 & 46.09 & 96.90 & 180.16 & 46.27 \\
\hline 106 & 42.91 & 45.64 & 92.14 & 313.59 & 45.81 \\
\hline 110 & 45.49 & 48.38 & 97.60 & 323.03 & 48.55 \\
\hline 115 & 49.12 & 50.13 & 105.28 & 188.19 & 50.31 \\
\hline 124 & 43.18 & 45.93 & 92.72 & 314.60 & 46.10 \\
\hline 129 & 45.65 & 46.60 & 97.94 & 181.18 & 46.77 \\
\hline 135 & 45.41 & 46.35 & 97.42 & 180.67 & 46.52 \\
\hline 148 & 44.50 & 47.33 & 95.50 & 319.43 & 47.50 \\
\hline 161 & 46.99 & 47.96 & 100.77 & 183.91 & 48.13 \\
\hline .177 & 45.55 & 46.49 & 97.73 & 180.97 & 46.67 \\
\hline 182 & 43.25 & 46.00 & 92.85 & 314.84 & 46.17 \\
\hline 198 & 45.90 & 48.81 & 98.46 & 324.50 & 48.98 \\
\hline 210 & 42.36 & 45.06 & 90.98 & 311.54 & 45.23 \\
\hline 214 & 42.77 & 45.49 & 91.84 & 313.06 & 45.66 \\
\hline 218 & 47.11 & 50.10 & 101.03 & 328.85 & 50.28 \\
\hline 221 & 47.24 & 48.22 & 101.30 & 184.42 & 48.39 \\
\hline 223 & 53.71 & 54.50 & 115.01 & 164.86 & 54.67 \\
\hline 230 & 51.06 & 53.73 & 109.40 & 309.63 & 53.90 \\
\hline 236 & 48.44 & 50.97 & 103.86 & 301.49 & 51.15 \\
\hline 238 & 43.48 & 46.25 & 93.35 & 315.71 & 46.42 \\
\hline 243 & 46.28 & 47.24 & 99.27 & 182.46 & 47.41 \\
\hline 248 & 43.47 & 45.74 & 93.32 & 285.40 & 45.92 \\
\hline 263 & 46.98 & 47.95 & 100.75 & 183.89 & 48.12 \\
\hline 280 & 49.89 & 52.49 & 106.91 & 306.00 & 52.66 \\
\hline 295 & 45.83 & 46.78 & 98.31 & 181.54 & 46.95 \\
\hline 313 & 49.79 & 50.82 & 106.70 & 189.53 & 50.99 \\
\hline 354 & 44.00 & 46.36 & 94.57 & 287.35 & 46.54 \\
\hline 358 & 43.56 & 46.34 & 93.53 & 316.01 & 46.51 \\
\hline 360 & 44.73 & 47.07 & 96.00 & 289.57 & 47.25 \\
\hline 361 & 47.31 & 49.51 & 101.44 & 280.82 & 49.68 \\
\hline
\end{tabular}


Table 12 ... PLENUM2 for Test G

\begin{tabular}{|c|c|c|c|c|c|}
\hline OLC & $\begin{array}{l}\text { Measured } \\
\text { Pressure } \\
\text { Inside USH } \\
\text { (psig) } \\
\end{array}$ & $\begin{array}{l}\text { Corrected } \\
\text { Pressure } \\
\text { Outside USH } \\
\text { (psig) }\end{array}$ & $\begin{array}{l}\text { Corrected } \\
\text { Head Outside } \\
\text { USH } \\
(f t)\end{array}$ & $\begin{array}{l}\text { Calculated } \\
\text { Assembly } \\
\text { Flow } \\
\text { (gpm) }\end{array}$ & $\begin{array}{l}\text { Adjusted } \\
\text { Plenum C-L } \\
\text { Pressure } \\
\text { (psig) }\end{array}$ \\
\hline 363 & 54.02 & 54.53 & 115.67 & 131.87 & 54.71 \\
\hline 367 & 54.97 & 56.14 & 117.67 & 201.88 & 56.31 \\
\hline 372 & 55.05 & $55.8 \varepsilon$ & 117.85 & 166.95 & 56.04 \\
\hline 373 & 58.58 & 59.33 & 125.32 & 160.64 & 59.51 \\
\hline 377 & 56.87 & 57.15 & 121.70 & 96.30 & 57.32 \\
\hline 382 & 44.65 & 46.73 & 95.82 & 272.74 & 46.91 \\
\hline 406 & 55.21 & 55.73 & 118.18 & 133.33 & 55.91 \\
\hline 432 & 45.31 & 47.42 & 97.21 & 274.77 & 47.59 \\
\hline 450 & 52.76 & 55.21 & 112.98 & 296.72 & 55.38 \\
\hline 471 & 48.23 & 48.69 & 103.41 & 124.52 & 48.86 \\
\hline 472 & 43.84 & 45.89 & 94.11 & 270.24 & 46.06 \\
\hline 475 & 52.07 & 52.32 & 111.54 & 92.14 & 52.49 \\
\hline 482 & 58.98 & 58.98 & 126.15 & 0.00 & 59.15 \\
\hline 484 & 59.72 & 59.72 & 127.72 & 0.00 & 59.89 \\
\hline 486 & 61.84 & 61.84 & 132.20 & 0.00 & 62.01 \\
\hline 487 & 57.37 & 57.37 & 122.75 & 0.00 & 57.54 \\
\hline 488 & 58.13 & 58.13 & 124.36 & 0.00 & 58.30 \\
\hline 490 & 61.89 & 61.89 & 132.31 & 0.00 & 62.06 \\
\hline 491 & 59.13 & 59.41 & 126.48 & 98.19 & 59.59 \\
\hline 492 & 61.55 & 61.55 & 131.60 & 0.00 & 61.72 \\
\hline 493 & 60.49 & 60.49 & 129.36 & 0.00 & 60.66 \\
\hline 494 & 61.86 & 61.86 & 132.26 & 0.00 & 62.04 \\
\hline 495 & 61.04 & 61.04 & 130.52 & 0.00 & 61.21 \\
\hline 496 & 58.55 & 58.55 & 125.24 & 0.00 & 58.72 \\
\hline 497 & 61.52 & 61.52 & 131.54 & 0.00 & 61.70 \\
\hline 498 & 60.93 & 60.93 & 130.28 & 0.00 & 61.10 \\
\hline 499 & 58.86 & 58.86 & 125.90 & 0.00 & 59.03 \\
\hline 500 & 56.98 & 56.98 & 121.93 & 0.00 & 57.16 \\
\hline 502 & 58.07 & 58.07 & 124.23 & 0.00 & 58.25 \\
\hline 504 & 56.50 & 56.50 & 120.92 & 0.00 & 56.68 \\
\hline 506 & 53.98 & 53.98 & 115.57 & 0.00 & 54.15 \\
\hline 507 & 48.64 & 49.27 & 104.27 & 146.45 & 49.44 \\
\hline 508 & 54.50 & 54.50 & 116.67 & 0.00 & 54.67 \\
\hline 509 & 51.38 & 51.62 & 110.06 & 91.52 & 51.79 \\
\hline 510 & 55.73 & 55.73 & 119.28 & 0.00 & 55.91 \\
\hline 512 & 56.63 & 56.63 & 121.19 & 0.00 & 56.81 \\
\hline 520 & 59.03 & 59.03 & 126.26 & 0.00 & 59.20 \\
\hline 524 & 60.20 & 60.20 & 128.75 & 0.00 & .60 .38 \\
\hline
\end{tabular}


Table 12 ... PLENUM2 for Test G

\begin{tabular}{|cccccc} 
OLC & $\begin{array}{c}\text { Measured } \\
\text { Pressure } \\
\text { Inside USH } \\
\text { (psig) }\end{array}$ & $\begin{array}{c}\text { Corrected } \\
\text { Pressure } \\
\text { Outside USH } \\
\text { (psig) }\end{array}$ & $\begin{array}{c}\text { Corrected } \\
\text { Head Outside } \\
\text { LSH } \\
(\text { ft) }\end{array}$ & $\begin{array}{c}\text { Calculated } \\
\text { Assembly } \\
\text { Flow } \\
\text { (gpm) }\end{array}$ & $\begin{array}{c}\text { Adjusted } \\
\text { Plenum C-L } \\
\text { Pressure } \\
\text { (psig) }\end{array}$ \\
\hline 539 & 58.94 & 58.94 & 126.08 & 0.00 & 59.12 \\
542 & 58.38 & 58.38 & 124.89 & 0.00 & 58.56 \\
559 & 59.93 & 59.93 & 128.17 & 0.00 & 60.10 \\
562 & 61.74 & 61.74 & 131.99 & 0.00 & 61.91 \\
579 & 59.74 & 59.74 & 127.76 & 0.00 & 59.91 \\
582 & 59.43 & 59.43 & 127.10 & 0.00 & 59.60 \\
592 & 57.78 & 57.78 & 123.61 & 0.00 & 57.95 \\
593 & 56.17 & 56.17 & 120.22 & 0.00 & 56.35 \\
595 & 55.57 & 55.57 & 118.93 & 0.00 & 55.74 \\
596 & 54.63 & 54.63 & 116.94 & 0.00 & 54.80 \\
597 & 52.74 & 52.74 & 112.96 & 0.00 & 52.92 \\
598 & 54.16 & 54.16 & 115.96 & 0.00 & 54.33 \\
599 & 57.17 & 57.17 & 122.33 & 0.00 & 57.35 \\
600 & 58.16 & 58.16 & 124.43 & 0.00 & 58.34 \\
\hline
\end{tabular}


Table 13 ... PLENUM2 for Test $H$

\begin{tabular}{|c|c|c|c|c|c|}
\hline CL & $\begin{array}{l}\text { Measured } \\
\text { Pressure } \\
\text { Inside USH } \\
\text { (psig) } \\
\end{array}$ & $\begin{array}{l}\text { Corrected } \\
\text { Pressure } \\
\text { Outside USH } \\
\text { (psig) }\end{array}$ & $\begin{array}{l}\text { Corrected } \\
\text { Head Outside } \\
\text { LSH } \\
\text { (ft) }\end{array}$ & $\begin{array}{l}\text { Calculated } \\
\text { Assembly } \\
\text { Flow } \\
\text { (gpm) }\end{array}$ & $\begin{array}{l}\text { Adjusted } \\
\text { Plenum C-L } \\
\text { Pressure } \\
\text { (psig) }\end{array}$ \\
\hline 1 & 74.19 & 75.73 & 158.34 & 233.23 & 75.90 \\
\hline 6 & 70.58 & 75.05 & 150.71 & 404.10 & 75.22 \\
\hline 15 & 73.74 & 75.27 & 157.38 & 232.49 & 75.44 \\
\hline 26 & 70.84 & 75.31 & 151.25 & 404.84 & 75.49 \\
\hline 34 & 70.57 & 75.03 & 150.67 & 404.05 & 75.20 \\
\hline 47 & 73.12 & 74.64 & 156.08 & 231.48 & 74.81 \\
\hline 59 & 71.12 & 75.61 & 151.84 & 405.65 & 75.78 \\
\hline 71 & 73.73 & 75.27 & 157.37 & 232.49 & 75.44 \\
\hline 83 & 72.82 & 74.33 & 155.44 & 230.98 & 74.51 \\
\hline 106 & 69.04 & 73.40 & 147.43 & 399.55 & 73.57 \\
\hline 110 & 72.92 & 77.53 & 155.66 & 410.89 & 77.70 \\
\hline 115 & 78.48 & 80.11 & 167.41 & 240.17 & 80.28 \\
\hline 124 & 69.97 & 74.39 & 149.40 & 402.29 & 74.56 \\
\hline 129 & 73.59 & 75.12 & 157.08 & 232.26 & 75.29 \\
\hline 135 & 72.96 & 74.47 & 155.73 & 231.21 & 74.65 \\
\hline 148 & 71.57 & 76.09 & 152.79 & 406.96 & 76.26 \\
\hline 161 & 76.16 & 77.74 & 162.50 & 236.44 & 77.91 \\
\hline 177 & 73.13 & 74.65 & 156.10 & 231.49 & 74.82 \\
\hline 182 & 69.22 & 73.60 & 147.83 & 400.11 & 73.77 \\
\hline 198 & 74.52 & 79.23 & 159.04 & 415.46 & 79.40 \\
\hline 210 & 67.74 & 72.03 & 144.70 & 395.71 & 72.20 \\
\hline 214 & 68.61 & 72.95 & 146.54 & 398.30 & 73.12 \\
\hline 218 & 75.21 & 79.96 & 160.50 & 417.42 & 80.13 \\
\hline 221 & 75.78 & 77.35 & 161.70 & 235.82 & 77.52 \\
\hline 223 & 85.83 & 87.09 & 182.99 & 209.70 & 87.26 \\
\hline 230 & 81.48 & 85.70 & 173.77 & 392.51 & 85.87 \\
\hline 236 & 77.73 & 81.75 & 165.83 & 383.21 & 81.92 \\
\hline 238 & 70.42 & 74.88 & 150.37 & 403.63 & 75.05 \\
\hline 243 & 74.59 & 76.14 & 159.20 & 233.90 & 76.32 \\
\hline 248 & 69.91 & 73.53 & 149.28 & 363.11 & 73.71 \\
\hline 263 & 75.28 & 76.85 & 160.66 & 235.02 & 77.02 \\
\hline 280 & 80.81 & 84.99 & 172.35 & 390.86 & 85.16 \\
\hline 295 & 73.83 & 75.36 & 157.57 & 232.64 & 75.53 \\
\hline 313 & 79.88 & 81.55 & 170.39 & 242.40 & 81.72 \\
\hline 354 & 70.38 & 74.03 & 150.28 & 364.36 & 74.20 \\
\hline 358 & 69.80 & 74.21 & 149.05 & 401.80 & 74.39 \\
\hline 360 & 71.98 & 75.72 & 153.67 & 368.55 & 75.89 \\
\hline 361 & 76.17 & 79.68 & 162.53 & 357.33 & 79.86 \\
\hline
\end{tabular}


Table 13 ... PLENUM2 for Test H

\begin{tabular}{|c|c|c|c|c|c|}
\hline ما & $\begin{array}{l}\text { Measured } \\
\text { Pressure } \\
\text { Inside USH } \\
\text { (psig) } \\
\end{array}$ & $\begin{array}{l}\text { Corrected } \\
\text { Pressure } \\
\text { Outside USH } \\
\text { (psig) } \\
\end{array}$ & $\begin{array}{c}\text { Corrected } \\
\text { Head Outside } \\
\text { USH } \\
(f t) \\
\end{array}$ & $\begin{array}{l}\text { Calculated } \\
\text { Assembly } \\
\text { Flow } \\
\text { (gpm) } \\
\end{array}$ & $\begin{array}{l}\text { Adjusted } \\
\text { Plenum C-L } \\
\text { Pressure } \\
\text { (psig) } \\
\end{array}$ \\
\hline 363 & 87.26 & 88.08 & 186.01 & 168.17 & 88.26 \\
\hline 367 & 88.25 & 90.09 & 188.10 & 255.86 & 90.27 \\
\hline 372 & 88.20 & 89.50 & 188.00 & 212.66 & 89.67 \\
\hline 373 & 93.38 & 94.56 & 198.96 & 202.69 & 94.73 \\
\hline 377 & 91.49 & 91.93 & 194.96 & 122.24 & 92.10 \\
\hline 382 & 72.77 & 76.13 & 155.33 & 349.15 & 76.30 \\
\hline 406 & 89.03 & 89.87 & 189.76 & 169.89 & 90.04 \\
\hline 432 & 72.96 & 76.33 & 155.73 & 349.62 & 76.50 \\
\hline 450 & 85.78 & 89.73 & 182.87 & 379.53 & 89.90 \\
\hline 471 & 78.11 & 78.85 & 166.64 & 158.97 & 79.02 \\
\hline 472 & 70.45 & 73.70 & 150.42 & 343.47 & 73.88 \\
\hline 475 & 83.89 & 84.29 & 178.87 & 117.02 & 84.47 \\
\hline 482 & 94.98 & 94.98 & 202.35 & 0.00 & 95.15 \\
\hline 484 & 96.20 & 96.20 & 204.92 & 0.00 & 96.37 \\
\hline 486 & 99.23 & 99.23 & 211.35 & 0.00 & 99.41 \\
\hline 487 & 92.18 & 92.18 & 196.42 & 0.00 & 92.36 \\
\hline 488 & 93.95 & 93.95 & 200.15 & 0.00 & 94.12 \\
\hline 490 & 98.75 & 98.75 & 210.32 & 0.00 & 98.92 \\
\hline 491 & 95.09 & 95.55 & 202.58 & 124.63 & 95.72 \\
\hline 492 & 99.32 & 99.32 & 211.52 & 0.00 & 99.49 \\
\hline 493 & 96.75 & 96.75 & 206.09 & 0.00 & 96.92 \\
\hline 494 & 98.78 & 98.78 & 210.39 & 0.00 & 98.95 \\
\hline 495 & 97.83 & 97.83 & 208.38 & 0.00 & 98.01 \\
\hline 496 & 94.85 & 94.85 & 202.07 & 0.00 & 95.02 \\
\hline 497 & 97.02 & 97.02 & 206.65 & 0.00 & 97.19 \\
\hline 498 & 96.75 & 96.75 & 206.09 & 0.00 & 96.92 \\
\hline 499 & 94.41 & 94.41 & 201.13 & 0.00 & 94.58 \\
\hline 500 & 90.89 & 90.89 & 193.69 & 0.00 & 91.07 \\
\hline 502 & 94.49 & 94.49 & 201.31 & 0.00 & 94.67 \\
\hline 504 & 94.29 & 94.29 & 200.89 & 0.00 & 94.47 \\
\hline 506 & 90.48 & 90.48 & 192.81 & 0.00 & 90.65 \\
\hline 507 & 79.71 & 80.72 & 170.03 & 187.29 & 80.89 \\
\hline 508 & 93.21 & 93.21 & 198.60 & 0.00 & 93.38 \\
\hline 509 & 82.29 & 82.69 & 175.49 & 115.90 & 82.86 \\
\hline 510 & 91.00 & 91.00 & 193.92 & 0.00 & 91.17 \\
\hline 512 & 94.36 & 94.36 & 201.02 & 0.00 & 94.53 \\
\hline 520 & 94.51 & 94.51 & 201.34 & 0.00 & 94.68 \\
\hline 524 & 97.62 & 97.62 & 207.93 & 0.00 & 97.79 \\
\hline
\end{tabular}


Table 13 ... PLENUM2 for Test $H$

\begin{tabular}{|ccccrcc}
\multicolumn{1}{c}{$\begin{array}{c}\text { Measured } \\
\text { Pressure } \\
\text { Inside USH } \\
\text { OLC }\end{array}$} & $\begin{array}{c}\text { Corrected } \\
\text { Pressure } \\
\text { Outside USH } \\
\text { (psig) }\end{array}$ & $\begin{array}{c}\text { Corrected } \\
\text { Head Outside } \\
\text { USH } \\
(f t)\end{array}$ & $\begin{array}{c}\text { Calculated } \\
\text { Assembly } \\
\text { Flow } \\
\text { (gpm) }\end{array}$ & $\begin{array}{c}\text { Adjusted } \\
\text { Plenum C-L } \\
\text { Pressure } \\
\text { (psig) }\end{array}$ \\
\hline 539 & 95.07 & 95.07 & 202.53 & 0.00 & 95.24 \\
542 & 93.44 & 93.44 & 199.09 & 0.00 & 93.62 \\
559 & 94.37 & 94.37 & 201.04 & 0.00 & 94.54 \\
562 & 98.18 & 98.18 & 209.11 & 0.00 & 98.35 \\
579 & 96.38 & 96.38 & 205.30 & 0.00 & 96.55 \\
582 & 96.18 & 96.18 & 204.89 & 0.00 & 96.35 \\
592 & 94.66 & 94.66 & 201.66 & 0.00 & 94.83 \\
593 & 90.82 & 90.82 & 193.54 & 0.00 & 90.99 \\
595 & 88.47 & 88.47 & 188.55 & 0.00 & 88.64 \\
596 & 84.64 & 84.64 & 180.45 & 0.00 & 84.81 \\
597 & 82.86 & 82.86 & 176.69 & 0.00 & 83.03 \\
598 & 85.44 & 85.44 & 182.15 & 0.00 & 85.61 \\
599 & 91.34 & 91.34 & 194.64 & 0.00 & 91.51 \\
600 & 93.39 & 93.39 & 198.98 & 0.00 & 93.56 \\
\hline
\end{tabular}


Table 14 ... PLENUM2 for Test 1

\begin{tabular}{|c|c|c|c|c|c|}
\hline OLC & $\begin{array}{l}\text { Measured } \\
\text { Pressure } \\
\text { Inside USH } \\
\text { (psig) } \\
\end{array}$ & $\begin{array}{l}\text { Corrected } \\
\text { Pressure } \\
\text { Outside USH } \\
\text { (psig) } \\
\end{array}$ & $\begin{array}{l}\text { Corrected } \\
\text { Head Outside } \\
\text { USH } \\
\text { (ft) }\end{array}$ & $\begin{array}{l}\text { Calculated } \\
\text { Assembly } \\
\text { Flow } \\
\text { (gpm) } \\
\end{array}$ & $\begin{array}{l}\text { Adjusted } \\
\text { Plenum } C \cdot L \\
\text { Pressure } \\
\text { (psig) } \\
\end{array}$ \\
\hline 1 & 70.46 & 71.93 & 150.47 & 227.07 & 72.10 \\
\hline 6 & 67.16 & 71.41 & 143.48 & 394.00 & 71.58 \\
\hline 15 & 69.98 & 71.44 & 149.45 & 226.26 & 71.61 \\
\hline 26 & 67.26 & 71.52 & 143.69 & 394.30 & 71.69 \\
\hline 34 & 66.95 & 71.18 & 143.02 & 393.35 & 71.35 \\
\hline 47 & 69.49 & 70.93 & 148.40 & 225.43 & 71.10 \\
\hline 59 & 67.54 & 71.82 & 144.29 & 395.14 & 71.99 \\
\hline 71 & 70.04 & 71.50 & 149.57 & 226.36 & 71.67 \\
\hline 83 & 69.14 & 70.58 & 147.67 & 224.84 & 70.75 \\
\hline 106 & 65.68 & 69.84 & 140.35 & 389.55 & 70.01 \\
\hline 110 & 69.15 & 73.52 & 147.69 & 399.91 & 73.70 \\
\hline 115 & 74.66 & 76.21 & 159.35 & 234.02 & 76.38 \\
\hline 124 & 66.23 & 70.42 & 141.50 & 391.19 & 70.59 \\
\hline 129 & 69.95 & 71.40 & 149.38 & 226.20 & 71.57 \\
\hline 135 & 69.35 & 70.79 & 148.10 & 225.19 & 70.96 \\
\hline 148 & 67.81 & 72.09 & 144.84 & 395.92 & 72.27 \\
\hline 161 & 72.31 & 73.81 & 154.37 & 230.15 & 73.98 \\
\hline 177 & 69.51 & 70.96 & 148.46 & 225.47 & 71.13 \\
\hline 182 & 65.91 & 70.08 & 140.83 & 390.23 & 70.25 \\
\hline 198 & 7.0 .77 & 75.24 & 151.11 & 404.65 & 75.41 \\
\hline 210 & 64.26 & 68.33 & 137.34 & 385.22 & 68.50 \\
\hline 214 & 65.22 & 69.34 & 139.36 & 388.13 & 69.51 \\
\hline 218 & 71.61 & 76.14 & 152.90 & 407.12 & 76.31 \\
\hline 221 & 71.97 & 73.46 & 153.65 & 229.58 & 73.63 \\
\hline 223 & 81.41 & 82.60 & 173.64 & 204.09 & 82.77 \\
\hline 230 & 77.41 & 81.42 & 165.17 & 382.43 & 81.59 \\
\hline 236 & 73.77 & 77.60 & 157.47 & 373.19 & 77.77 \\
\hline 238 & 66.82 & 71.05 & 142.75 & 392.97 & 71.22 \\
\hline 243 & 70.79 & 72.26 & 151.17 & 227.62 & 72.44 \\
\hline 248 & 66.42 & 69.86 & 141.90 & 353.80 & 70.04 \\
\hline 263 & 71.66 & 73.15 & 153.00 & 229.07 & 73.32 \\
\hline 280 & 76.76 & 80.74 & 163.80 & 380.81 & 80.91 \\
\hline 295 & 70.20 & 71.65 & 149.90 & 226.62 & 71.83 \\
\hline 313 & 75.83 & 77.41 & 161.83 & 235.93 & 77.58 \\
\hline 354 & 66.87 & 70.34 & 142.85 & 355.01 & 70.51 \\
\hline 358 & 66.42 & 70.62 & 141.90 & 391.76 & 70.79 \\
\hline 360 & 68.29 & 71.84 & 145.87 & 358.84 & 72.01 \\
\hline 361 & 72.43 & 75.77 & 154.62 & 348.34 & 75.94 \\
\hline
\end{tabular}


Table 14 ... PLENUM2 for Test 1

\begin{tabular}{|c|c|c|c|c|c|}
\hline CL & $\begin{array}{l}\text { Measured } \\
\text { Pressure } \\
\text { Inside USH } \\
\text { (psig) }\end{array}$ & $\begin{array}{l}\text { Corrected } \\
\text { 'Pressure } \\
\text { Outside USH } \\
\text { (psig) }\end{array}$ & $\begin{array}{l}\text { Corrected } \\
\text { Head Outside } \\
\text { USH } \\
(f t)\end{array}$ & $\begin{array}{l}\text { Calculated } \\
\text { Assembly } \\
\text { Flow } \\
\text { (gpm) }\end{array}$ & $\begin{array}{l}\text { Adjusted } \\
\text { Plenum C-L } \\
\text { Pressure } \\
\text { (psig) }\end{array}$ \\
\hline 363 & 82.80 & 83.58 & 176.58 & 163.75 & 83.75 \\
\hline 367 & 83.93 & 85.69 & 178.98 & 249.52 & 85.86 \\
\hline 372 & 83.85 & 85.07 & 178.79 & 207.20 & 85.25 \\
\hline 373 & 88.67 & 89.79 & 189.00 & 197.52 & 89.96 \\
\hline 377 & 86.89 & 87.31 & 185.23 & 119.11 & 87.48 \\
\hline 382 & 69.07 & 72.27 & 147.53 & 340.07 & 72.44 \\
\hline 406 & 84.59 & 85.38 & 180.36 & 165.54 & 85.55 \\
\hline 432 & 69.36 & 72.57 & 148.14 & 340.79 & 72.74 \\
\hline 450 & 81.35 & 85.10 & 173.51 & 369.48 & 85.27 \\
\hline 471 & 74.25 & 74.94 & 158.47 & 154.93 & 75.12 \\
\hline 472 & 67.00 & 70.10 & 143.13 & 334.85 & 70.27 \\
\hline 475 & 79.62 & 80.01 & 169.86 & 114.00 & 80.18 \\
\hline 482 & 90.52 & 90.52 & 192.91 & 0.00 & 90.69 \\
\hline 484 & 91.40 & 91.40 & 194.79 & 0.00 & 91.58 \\
\hline 486 & 94.47 & 94.47 & 201.27 & 0.00 & 94.64 \\
\hline 487 & 87.42 & 87.42 & 186.36 & 0.00 & 87.60 \\
\hline 488 & 89.22 & 89.22 & 190.17 & 0.00 & 89.39 \\
\hline 490 & 94.00 & 94.00 & 200.29 & 0.00 & 94.17 \\
\hline 491 & 90.38 & 90.82 & 192.63 & 121.50 & 90.99 \\
\hline 492 & 94.27 & 94.27 & 200.86 & 0.00 & 94.44 \\
\hline 493 & 92.09 & 92.09 & 196.24 & 0.00 & 92.26 \\
\hline 494 & 93.81 & 93.81 & 199.89 & 0.00 & 93.99 \\
\hline 495 & 92.92 & 92.92 & 198.00 & 0.00 & 93.09 \\
\hline 496 & 90.18 & 90.18 & 192.19 & 0.00 & 90.35 \\
\hline 497 & 92.11 & 92.11 & 196.29 & 0.00 & 92.29 \\
\hline 498 & 92.11 & 92.11 & 196.28 & 0.00 & 92.28 \\
\hline 499 & 89.67 & 89.67 & 191.11 & 0.00 & 89.84 \\
\hline 500 & 86.40 & 86.40 & 184.19 & 0.00 & 86.57 \\
\hline 502 & 89.77 & 89.77 & 191.33 & 0.00 & 89.94 \\
\hline 504 & 89.18 & 89.18 & 190.09 & 0.00 & 89.35 \\
\hline 506 & 85.45 & 85.45 & 182.19 & 0.00 & 85.63 \\
\hline 507 & 75.64 & 76.60 & 161.43 & 182.46 & 76.78 \\
\hline 508 & 87.70 & 87.70 & 186.95 & 0.00 & 87.87 \\
\hline 509 & 78.52 & 78.89 & 167.51 & 113.20 & 79.07 \\
\hline 510 & 86.07 & 86.07 & 183.50 & 0.00 & 86.24 \\
\hline 512 & 89.24 & 89.24 & 190.20 & 0.00 & 89.41 \\
\hline 520 & 90.03 & 90.03 & 191.88 & 0.00 & 90.20 \\
\hline 524 & 93.16 & 93.16 & 198.50 & 0.00 & 93.33 \\
\hline
\end{tabular}


Table $14 \ldots$ PLENUM2 for Test 1

\begin{tabular}{|cccccc|}
\multicolumn{1}{c|}{$\begin{array}{c}\text { Measured } \\
\text { Pressure } \\
\text { Inside USH } \\
\text { OLC }\end{array}$} & $\begin{array}{c}\text { Corrected } \\
\text { (psig) }\end{array}$ & $\begin{array}{c}\text { Pressure } \\
\text { Outside USH } \\
\text { (psig) }\end{array}$ & $\begin{array}{c}\text { Corrected } \\
\text { Head Outside } \\
\text { LSH } \\
\text { (ft) }\end{array}$ & $\begin{array}{c}\text { Calculated } \\
\text { Assembly } \\
\text { Flow } \\
\text { (gpm) }\end{array}$ & $\begin{array}{c}\text { Adjusted } \\
\text { Plenum C.L } \\
\text { Pressure } \\
\text { (psig) }\end{array}$ \\
\hline 539 & 90.38 & 90.38 & 192.61 & 0.00 & 90.55 \\
542 & 88.68 & 88.68 & 189.02 & 0.00 & 88.85 \\
559 & 89.72 & 89.72 & 191.23 & 0.00 & 89.90 \\
562 & 93.35 & 93.35 & 198.91 & 0.00 & 93.52 \\
579 & 91.62 & 91.62 & 195.24 & 0.00 & 91.79 \\
582 & 91.40 & 91.40 & 194.79 & 0.00 & 91.58 \\
592 & 90.01 & 90.01 & 191.84 & 0.00 & 90.19 \\
593 & 86.30 & 86.30 & 183.98 & 0.00 & 86.47 \\
595 & 84.32 & 84.32 & 179.79 & 0.00 & 84.49 \\
596 & 81.13 & 81.13 & 173.03 & 0.00 & 81.30 \\
597 & 78.52 & 78.52 & 167.53 & 0.00 & 78.70 \\
598 & 81.31 & 81.31 & 173.42 & 0.00 & 81.48 \\
599 & 86.84 & 86.84 & 185.12 & 0.00 & 87.01 \\
600 & 88.90 & 88.90 & 189.49 & 0.00 & 89.07 \\
\hline
\end{tabular}


Table 15 ... PLENUM2 for Test J

\begin{tabular}{|c|c|c|c|c|c|}
\hline ع & $\begin{array}{l}\text { Measured } \\
\text { Pressure } \\
\text { Inside USH } \\
\text { (psig) }\end{array}$ & $\begin{array}{l}\text { Corrected } \\
\text { Pressure } \\
\text { Outside USH } \\
\text { (psig) } \\
\end{array}$ & $\begin{array}{c}\text { Corrected } \\
\text { Head Outside } \\
\text { USH } \\
(f t)\end{array}$ & $\begin{array}{l}\text { Calculated } \\
\text { Assembly } \\
\text { Flow } \\
\text { (gpm) } \\
\end{array}$ & $\begin{array}{l}\text { Adjusted } \\
\text { Plenum C.L } \\
\text { Pressure } \\
\text { (psig) } \\
\end{array}$ \\
\hline 1 & 48.10 & 49.10 & 103.09 & 186.11 & 49.35 \\
\hline 6 & 46.18 & 49.11 & 99.03 & 325.44 & 49.36 \\
\hline 15 & 48.29 & 49.29 & 103.48 & 186.48 & 49.54 \\
\hline 26 & 46.11 & 49.04 & 98.89 & 325.20 & 49.29 \\
\hline 34 & 47.18 & 50.18 & 101.15 & 329.01 & 50.43 \\
\hline 47 & 48.06 & 49.06 & 103.00 & 186.02 & 49.30 \\
\hline 59 & 46.82 & 49.79 & 100.38 & 327.72 & 50.04 \\
\hline 71 & 47.41 & 48.40 & 101.63 & 184.72 & 48.64 \\
\hline 83 & 48.72 & 49.73 & 104.39 & 187.34 & 49.97 \\
\hline 106 & 45.42 & 48.31 & 97.42 & 322.70 & 48.55 \\
\hline 110 & 44.80 & 47.64 & 96.10 & 320.45 & 47.89 \\
\hline 115 & 47.90 & 48.89 & 102.66 & 185.70 & 49.14 \\
\hline 124 & 46.06 & 48.98 & 98.76 & 324.99 & 49.23 \\
\hline 129 & 48.10 & 49.09 & 103.08 & 186.10 & 49.34 \\
\hline 135 & 48.95 & 49.97 & 104.90 & 187.81 & 50.22 \\
\hline 148 & 46.49 & 49.44 & 99.68 & 326.54 & 49.69 \\
\hline 161 & 50.99 & 52.05 & 109.21 & 191.84 & 52.30 \\
\hline 177 & 51.49 & 52.56 & 110.26 & 192.81 & 52.81 \\
\hline 182 & 48.43 & 51.51 & 103.80 & 333.43 & 51.76 \\
\hline 198 & 53.67 & 57.08 & 114.88 & 351.32 & 57.32 \\
\hline 210 & 45.59 & 48.48 & 97.77 & 323.31 & 48.73 \\
\hline 214 & 44.80 & 47.65 & 96.11 & 320.47 & 47.90 \\
\hline 218 & 43.81 & 46.60 & 94.01 & 316.84 & 46.84 \\
\hline 221 & 48.86 & 49.87 & 104.69 & 187.62 & 50.12 \\
\hline 223 & 49.32 & 50.04 & 105.67 & 157.76 & 50.29 \\
\hline 230 & 48.70 & 51.24 & 104.36 & 302.21 & 51.49 \\
\hline 236 & 47.76 & 50.25 & 102.36 & 299.24 & 50.50 \\
\hline 238 & 46.25 & 49.19 & 99.18 & 325.70 & 49.44 \\
\hline 243 & 47.88 & 48.88 & 102.63 & 185.67 & 49.13 \\
\hline 248 & 46.50 & 48.93 & 99.71 & 295.24 & 49.18 \\
\hline 263 & 52.32 & 53.40 & 112.01 & 194.41 & 53.65 \\
\hline 280 & 56.97 & 59.93 & 121.85 & 327.20 & 60.18 \\
\hline 295 & 50.00 & 51.03 & 107.10 & 189.88 & 51.28 \\
\hline 313 & 58.09 & 59.29 & 124.22 & 205.28 & 59.54 \\
\hline 354 & 47.33 & 49.80 & 101.46 & 297.89 & 50.05 \\
\hline 358 & 45.87 & 48.79 & 98.37 & 324.33 & 49.04 \\
\hline 360 & 46.76 & 49.21 & 100.26 & 296.07 & 49.46 \\
\hline 361 & 50.16 & 52.50 & 107.45 & 289.18 & 52.74 \\
\hline
\end{tabular}


Table 15 ... PLENUM2 for Test J

\begin{tabular}{|c|c|c|c|c|c|}
\hline C & $\begin{array}{l}\text { Measured } \\
\text { Pressure } \\
\text { Inside USH } \\
\text { (psig) } \\
\end{array}$ & $\begin{array}{l}\text { Corrected } \\
\text { Pressure } \\
\text { Outside USH } \\
\text { (psig) }\end{array}$ & $\begin{array}{l}\text { Corrected } \\
\text { Head Outside } \\
\text { USH } \\
\text { (ft) }\end{array}$ & $\begin{array}{l}\text { Calculated } \\
\text { Assembly } \\
\text { Flow } \\
\text { (gpm) } \\
\end{array}$ & $\begin{array}{l}\text { Adjusted } \\
\text { Plenum C.L } \\
\text { Pressure } \\
\text { (psig) } \\
\end{array}$ \\
\hline 363 & 54.65 & 55.17 & 116.95 & 132.61 & 55.41 \\
\hline 367 & 48.44 & 49.47 & 103.81 & 189.50 & 49.72 \\
\hline 372 & 49.56 & 50.29 & 106.18 & 158.15 & 50.54 \\
\hline 373 & 49.59 & 50.23 & 106.24 & 147.83 & 50.48 \\
\hline 377 & 51.66 & 51.90 & 110.62 & 91.75 & 52.15 \\
\hline 382 & 44.98 & 47.08 & 96.50 & 273.71 & 47.33 \\
\hline 406 & 64.26 & 64.87 & 137.28 & 143.95 & 65.11 \\
\hline 432 & 52.21 & 54.63 & 111.78 & 295.08 & 54.88 \\
\hline 450 & 63.69 & 66.64 & 136.07 & 326.29 & 66.89 \\
\hline 471 & 54.69 & 55.21 & 117.03 & 132.66 & 55.45 \\
\hline 472 & 48.30 & 50.55 & 103.51 & 283.71 & 50.80 \\
\hline 475 & 57.68 & 57.96 & 123.36 & 96.96 & 58.20 \\
\hline 482 & 66.91 & 66.91 & 142.88 & 0.00 & 67.16 \\
\hline 484 & 64.30 & 64.30 & 137.35 & 0.00 & 64.54 \\
\hline 486 & 62.26 & 62.26 & 133.04 & 0.00 & 62.50 \\
\hline 487 & 50.49 & 50.49 & 108.14 & 0.00 & 50.74 \\
\hline 488 & 51.52 & 51.52 & 110.33 & 0.00 & 51.77 \\
\hline 490 & 53.45 & 53.45 & 114.41 & 0.00 & 53.70 \\
\hline 491 & 50.54 & 50.78 & 108.26 & 90.75 & 51.03 \\
\hline 492 & 50.02 & 50.02 & 107.14 & 0.00 & 50.26 \\
\hline 493 & 50.46 & 50.46 & 108.09 & 0.00 & 50.71 \\
\hline 494 & 51.61 & 51.61 & 110.51 & 0.00 & 51.86 \\
\hline 495 & 51.00 & 51.00 & 109.23 & 0.00 & 51.25 \\
\hline 496 & 51.64 & 51.64 & 110.58 & 0.00 & 51.89 \\
\hline 497 & 51.82 & 51.82 & 110.95 & 0.00 & 52.07 \\
\hline 498 & 51.78 & 51.78 & 110.87 & 0.00 & 52.03 \\
\hline 499 & 52.34 & 52.34 & 112.06 & 0.00 & 52.59 \\
\hline 500 & 52.06 & 52.06 & 111.47 & 0.00 & 52.31 \\
\hline 502 & 51.96 & 51.96 & 111.26 & 0.00 & 52.21 \\
\hline 504 & 51.67 & 51.67 & 110.64 & 0.00 & 51.92 \\
\hline 506 & 52.26 & 52.26 & 111.89 & 0.00 & 52.51 \\
\hline 507 & 49.11 & 49.74 & 105.23 & 147.12 & 49.99 \\
\hline 508 & 51.90 & 51.90 & 111.14 & 0.00 & 52.15 \\
\hline 509 & 50.24 & 50.48 & 107.62 & 90.48 & 50.73 \\
\hline 510 & 51.92 & 51.92 & 111.16 & 0.00 & 52.16 \\
\hline 512 & 47.75 & 47.75 & 102.35 & 0.00 & 48.00 \\
\hline 520 & 66.06 & 66.06 & 141.09 & 0.00 & 66.31 \\
\hline 524 & 72.31 & 72.31 & 154.32 & 0.00 & 72.56 \\
\hline
\end{tabular}


Table 15 ... PLENUM2 for Test J

\begin{tabular}{|cccccc} 
& $\begin{array}{c}\text { Measured } \\
\text { Pressure } \\
\text { Inside USH } \\
\text { (psig) }\end{array}$ & $\begin{array}{c}\text { Corrected } \\
\text { Pressure } \\
\text { Outside USH } \\
\text { (psig) }\end{array}$ & $\begin{array}{c}\text { Corrected } \\
\text { Head Outside } \\
\text { LSH } \\
\text { (ft) }\end{array}$ & $\begin{array}{c}\text { Calculated } \\
\text { Assembly } \\
\text { Flow } \\
\text { (gpm) }\end{array}$ & $\begin{array}{c}\text { Adjusted } \\
\text { Plenum C.L } \\
\text { Pressure } \\
\text { (psig) }\end{array}$ \\
\hline $\mathbf{5 3 9}$ & 71.52 & 71.52 & 152.65 & 0.00 & 71.77 \\
$\mathbf{5 4 2}$ & 70.73 & 70.73 & 150.98 & 0.00 & 70.98 \\
$\mathbf{5 5 9}$ & 70.71 & 70.71 & 150.93 & 0.00 & 70.96 \\
$\mathbf{5 6 2}$ & 75.37 & 75.37 & 160.78 & 0.00 & 75.61 \\
$\mathbf{5 7 9}$ & 73.97 & 73.97 & 157.82 & 0.00 & 74.22 \\
$\mathbf{5 8 2}$ & 69.37 & 69.37 & 148.09 & 0.00 & 69.62 \\
$\mathbf{5 9 2}$ & 62.13 & 62.13 & 132.78 & 0.00 & 62.38 \\
$\mathbf{5 9 3}$ & 65.53 & 65.53 & 139.96 & 0.00 & 65.78 \\
$\mathbf{5 9 5}$ & 69.76 & 69.76 & 148.92 & 0.00 & 70.01 \\
$\mathbf{5 9 6}$ & 66.90 & 66.90 & 142.87 & 0.00 & 67.15 \\
$\mathbf{5 9 7}$ & 66.25 & 66.25 & 141.48 & 0.00 & 66.49 \\
$\mathbf{5 9 8}$ & 67.35 & 67.35 & 143.82 & 0.00 & 67.60 \\
$\mathbf{5 9 9}$ & 69.41 & 69.41 & 148.18 & 0.00 & 69.66 \\
600 & 69.66 & 69.66 & 148.71 & 0.00 & 69.91 \\
\hline
\end{tabular}


WSRC-TR-92-134

Task 91-033-1

DQ Summary for 1985 L-Area AC Flow Tests
March 10, 1992

Revision 0

Page 62 of 119

Table 16 ... PLENUM2 for Test K

\begin{tabular}{|c|c|c|c|c|c|}
\hline OLC & $\begin{array}{l}\text { Measured } \\
\text { Pressure } \\
\text { Inside USH } \\
\text { (psig) } \\
\end{array}$ & $\begin{array}{l}\text { Corrected } \\
\text { Pressure } \\
\text { Outside USH } \\
\text { (psig) }\end{array}$ & $\begin{array}{c}\text { Corrected } \\
\text { Head Outside } \\
\text { USH } \\
\text { (ft) }\end{array}$ & $\begin{array}{l}\text { Calculated } \\
\text { Assembly } \\
\text { Flow } \\
\text { (gpm) } \\
\end{array}$ & $\begin{array}{l}\text { Adjusted } \\
\text { Plenum C-L } \\
\text { Pressure } \\
\text { (psig) } \\
\end{array}$ \\
\hline 1 & 24.89 & 25.40 & 53.96 & 132.35 & 25.58 \\
\hline 6 & 24.04 & 2.5 .59 & 52.15 & 233.81 & 25.76 \\
\hline 15 & 24.55 & 25.06 & 53.24 & 131.41 & 25.23 \\
\hline 26 & 24.02 & 25.57 & 52.12 & 233.73 & 25.74 \\
\hline 34 & 23.93 & 25.48 & 51.93 & 233.30 & 25.65 \\
\hline 47 & 24.11 & 24.61 & 52.30 & 130.20 & 24.78 \\
\hline 59 & 23.40 & 24.91 & 50.80 & 230.66 & 25.08 \\
\hline 71 & 24.78 & 25.29 & 53.73 & 132.05 & 25.47 \\
\hline 83 & 25.07 & 25.59 & 54.34 & 132.84 & 25.76 \\
\hline 106 & 22.89 & 24.37 & 49.72 & 228.12 & 24.54 \\
\hline 110 & 26.60 & 28.31 & 57.58 & 246.04 & 28.48 \\
\hline 115 & 30.70 & 31.34 & 66.24 & 147.45 & 31.51 \\
\hline 124 & 23.66 & 25.19 & 51.36 & 231.96 & 25.36 \\
\hline 129 & 25.39 & 25.92 & 55.02 & 133.72 & 26.09 \\
\hline 135 & 25.16 & 25.68 & 54.53 & 133.09 & 25.86 \\
\hline 148 & 25.00 & 26.62 & 54.20 & 238.49 & 26.79 \\
\hline 161 & 26.16 & 26.70 & 56.64 & 135.77 & 26.87 \\
\hline 177 & 25.10 & 25.62 & 54.40 & 132.91 & 25.79 \\
\hline 182 & 23.68 & 25.21 & 51.40 & 232.07 & 25.38 \\
\hline 198 & 23.84 & 25.38 & 51.74 & 232.84 & 25.55 \\
\hline 210 & 24.49 & 26.07 & 53.12 & 236.03 & 26.25 \\
\hline 214 & 22.72 & 24.19 & 49.37 & 227.29 & 24.36 \\
\hline 218 & 30.51 & $3 \hat{c} .46$ & 65.84 & 263.66 & 32.64 \\
\hline 221 & 27.66 & 28.23 & 59.82 & 139.73 & 28.41 \\
\hline 223 & 37.29 & 37.84 & 80.18 & 136.70 & 38.01 \\
\hline 230 & 35.92 & 37.81 & 77.27 & 259.05 & 37.98 \\
\hline 236 & 33.83 & 35.62 & 72.87 & 251.37 & 35.79 \\
\hline 238 & 26.79 & 28.52 & 57.98 & 246.94 & $\therefore 8.69$ \\
\hline 243 & 28.05 & 28.63 & 60.64 & 140.74 & 28.80 \\
\hline 248 & 24.80 & 26.12 & 53.77 & 215.09 & 26.30 \\
\hline 263 & 27.04 & 27.60 & 58.50 & 138.10 & 27.77 \\
\hline 280 & 29.92 & 31.51 & 64.60 & 236.31 & 31.68 \\
\hline 295 & 25.06 & 25.58 & 54.33 & 132.82 & 25.76 \\
\hline 313 & 25.39 & 25.91 & 55.01 & 133.69 & 26.08 \\
\hline 354 & 24.38 & 25.68 & 52.89 & 213.27 & 25.86 \\
\hline 358 & 25.51 & 27.15 & 55.26 & 240.90 & 27.32 \\
\hline 360 & 24.73 & 26.05 & 53.63 & 214.79 & 26.22 \\
\hline 361 & 25.42 & 26.63 & 55.08 & 205.47 & 26.80 \\
\hline
\end{tabular}


Table 16 ... PLENUM2 for Test $\mathrm{K}$

\begin{tabular}{|c|c|c|c|c|c|}
\hline CL & $\begin{array}{l}\text { Measured } \\
\text { Pressure } \\
\text { Inside USH } \\
\text { (psig) }\end{array}$ & $\begin{array}{l}\text { Corrected } \\
\text { Pressure } \\
\text { Outside USH } \\
\text { (psig) }\end{array}$ & $\begin{array}{l}\text { Corrected } \\
\text { Head Outside } \\
\text { USH } \\
\text { (ft) }\end{array}$ & $\begin{array}{l}\text { Calculated } \\
\text { Assembly } \\
\text { Flow } \\
\text { (gpm) }\end{array}$ & $\begin{array}{l}\text { Adjusted } \\
\text { Plenum C-L } \\
\text { Pressure } \\
\text { (psig) }\end{array}$ \\
\hline 363 & 38.64 & 39.01 & 83.04 & 111.27 & 39.18 \\
\hline 367 & 40.86 & 41.73 & 87.73 & 174.04 & 41.91 \\
\hline 372 & 40.52 & 41.11 & 87.01 & 142.62 & 41.29 \\
\hline 373 & 45.41 & 46.00 & 97.36 & 141.48 & 46.17 \\
\hline 377 & 43.07 & 4.3 .27 & 92.40 & 83.75 & 43.44 \\
\hline 382 & 24.13 & 25.28 & 52.36 & 200.21 & 25.46 \\
\hline 406 & 34.19 & 34.52 & 73.63 & 104.62 & 34.69 \\
\hline 432 & 24.12 & 25.27 & 52.32 & 200.13 & 25.44 \\
\hline 450 & 26.09 & 27.33 & 56.49 & 208.13 & 27.50 \\
\hline 471 & 28.77 & 29.04 & 62.17 & 95.94 & 29.22 \\
\hline 472 & 25.34 & 26.54 & 54.90 & 205.12 & 26.71 \\
\hline 475 & 30.20 & 30.34 & 65.20 & 70.19 & 30.52 \\
\hline 482 & 44.37 & 44.37 & 95.16 & 0.00 & 44.55 \\
\hline 484 & 46.23 & 46.23 & 99.08 & 0.00 & 46.40 \\
\hline 486 & 49.14 & 49.14 & 105.24 & 0.00 & 49.31 \\
\hline 487 & 43.80 & 43.80 & 93.94 & 0.00 & 43.97 \\
\hline 488 & 44.78 & 44.78 & 96.02 & 0.00 & 44.95 \\
\hline 490 & 49.34 & 49.34 & 105.67 & 0.00 & 49.51 \\
\hline 491 & 46.10 & 46.32 & 98.81 & 86.65 & 46.49 \\
\hline 492 & 48.87 & 48.87 & 104.68 & 0.00 & 49.05 \\
\hline 493 & 47.37 & 47.27 & 101.50 & 0.00 & 47.54 \\
\hline 494 & 49.11 & 49.11 & 105.18 & 0.00 & 49.28 \\
\hline 495 & 48.25 & 48.25 & 103.36 & 0.00 & 48.42 \\
\hline 496 & 46.09 & 46.09 & 98.78 & 0.00 & 46.26 \\
\hline 437 & 48.79 & 48.79 & 104.49 & 0.00 & 48.96 \\
\hline 498 & 48.84 & 48.84 & 10461 & 0.00 & 49.01 \\
\hline 499 & 45.51 & 45.51 & 97.58 & 0.00 & 45.69 \\
\hline 500 & 41.49 & 41.49 & 89.06 & 0.00 & 41.66 \\
\hline 502 & 40.16 & 40.16 & 86.26 & .0 .00 & 40.34 \\
\hline 504 & 36.96 & 36.96 & 79.47 & 0.00 & 37.13 \\
\hline 506 & 29.27 & 29.27 & 63.22 & 0.00 & 29.44 \\
\hline 507 & 25.38 & 25.71 & 55.00 & 106.14 & 25.89 \\
\hline 508 & 31.68 & 31.68 & 68.32 & 0.00 & 31.85 \\
\hline 509 & 27.95 & 28.07 & 60.42 & 67.54 & 28.24 \\
\hline 510 & 29.39 & 29.39 & 63.47 & 0.00 & 29.56 \\
\hline 512 & 2222 & 22.22 & 48.32 & 0.00 & 22.40 \\
\hline $5: 0$ & 37.92 & 37.92 & 81.50 & 0.00 & 38.09 \\
\hline 524 & 39.96 & 39.96 & 85.84 & 0.00 & 40.14 \\
\hline
\end{tabular}


Table 16 ... PLENUM2 for Test K

\begin{tabular}{|cccccc|}
\multicolumn{1}{c}{$\begin{array}{c}\text { Measured } \\
\text { Pressure } \\
\text { Inside USH } \\
\text { OLC }\end{array}$} & $\begin{array}{c}\text { Coriected } \\
\text { (psig) }\end{array}$ & $\begin{array}{c}\text { Putssure } \\
\text { Outeside USH } \\
\text { (psig) }\end{array}$ & $\begin{array}{c}\text { Corrected } \\
\text { Head Outside } \\
\text { LSH } \\
\text { (ft) }\end{array}$ & $\begin{array}{c}\text { Calculated } \\
\text { Assembly } \\
\text { Flow } \\
\text { (gpm) }\end{array}$ & $\begin{array}{c}\text { Adjusted } \\
\text { Plenum C.L } \\
\text { Pressure } \\
\text { (psig) }\end{array}$ \\
\hline 539 & 38.88 & 38.88 & 83.55 & 0.00 & 39.06 \\
542 & 34.88 & 34.88 & 75.09 & 0.00 & 35.06 \\
559 & 27.21 & 27.21 & 58.86 & 0.00 & 27.38 \\
562 & 30.22 & 30.22 & 65.23 & 0.00 & 30.40 \\
579 & 28.91 & 28.91 & 62.46 & 0.00 & 29.08 \\
582 & 28.27 & 28.27 & 61.11 & 0.00 & 28.44 \\
592 & 24.65 & 24.65 & 53.44 & 0.00 & 24.82 \\
593 & 30.28 & 30.28 & 65.35 & 0.00 & 30.45 \\
595 & 32.54 & 32.54 & 70.14 & 0.00 & 32.72 \\
596 & 31.41 & 31.41 & 67.76 & 0.00 & 31.59 \\
597 & 24.25 & 24.25 & 52.60 & 0.00 & 24.42 \\
598 & 29.35 & 29.35 & 63.39 & 0.00 & 29.52 \\
599 & 38.01 & 38.01 & 81.71 & 0.00 & 38.19 \\
600 & 42.02 & 42.02 & 90.19 & 0.00 & 42.20 \\
\hline
\end{tabular}




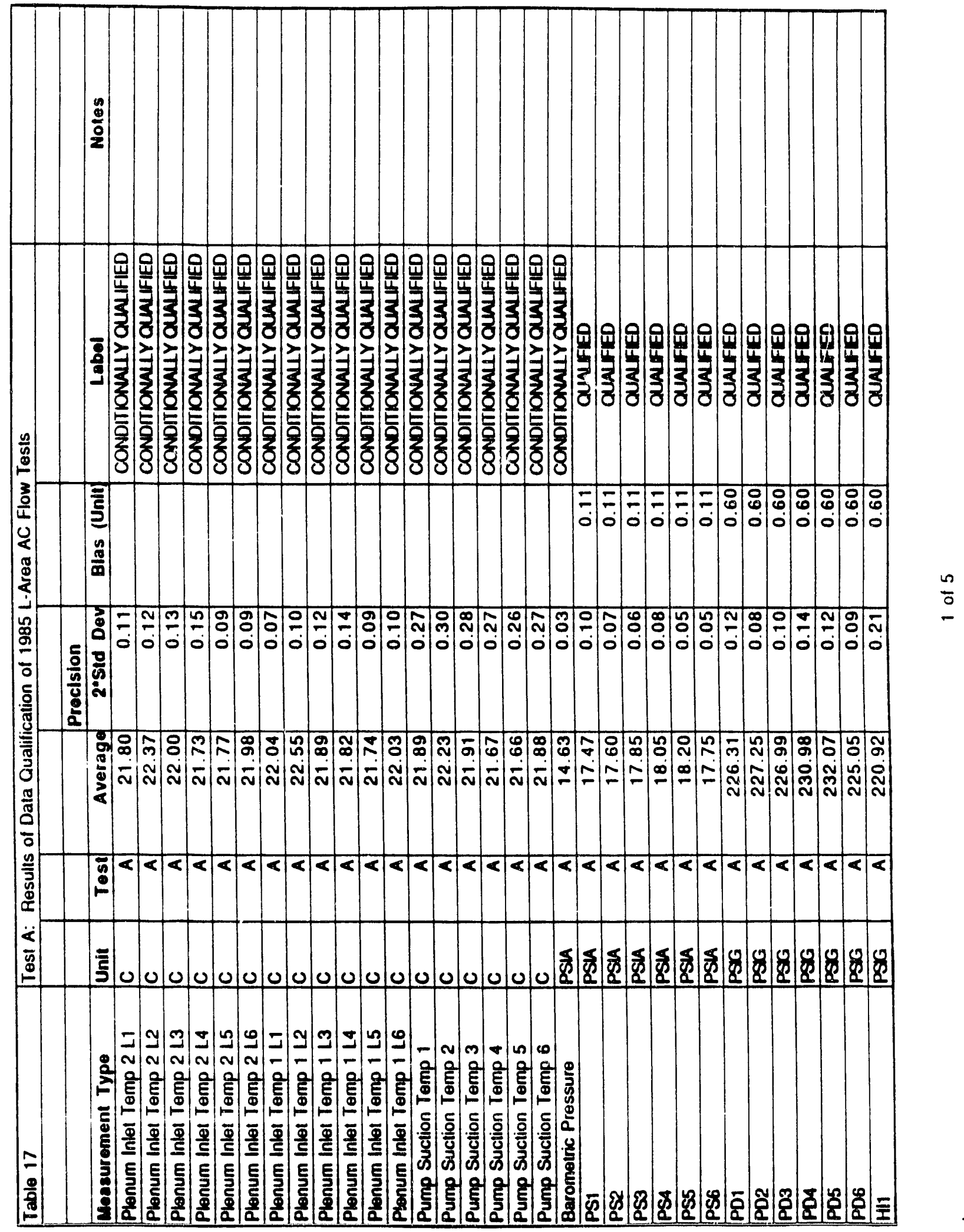


WSRC-TR-92-134

Task 91-033-1

DQ Summary for 1985 L-Area AC Flow Tests
March 10, 1992

Revision 0

Page 66 of 119

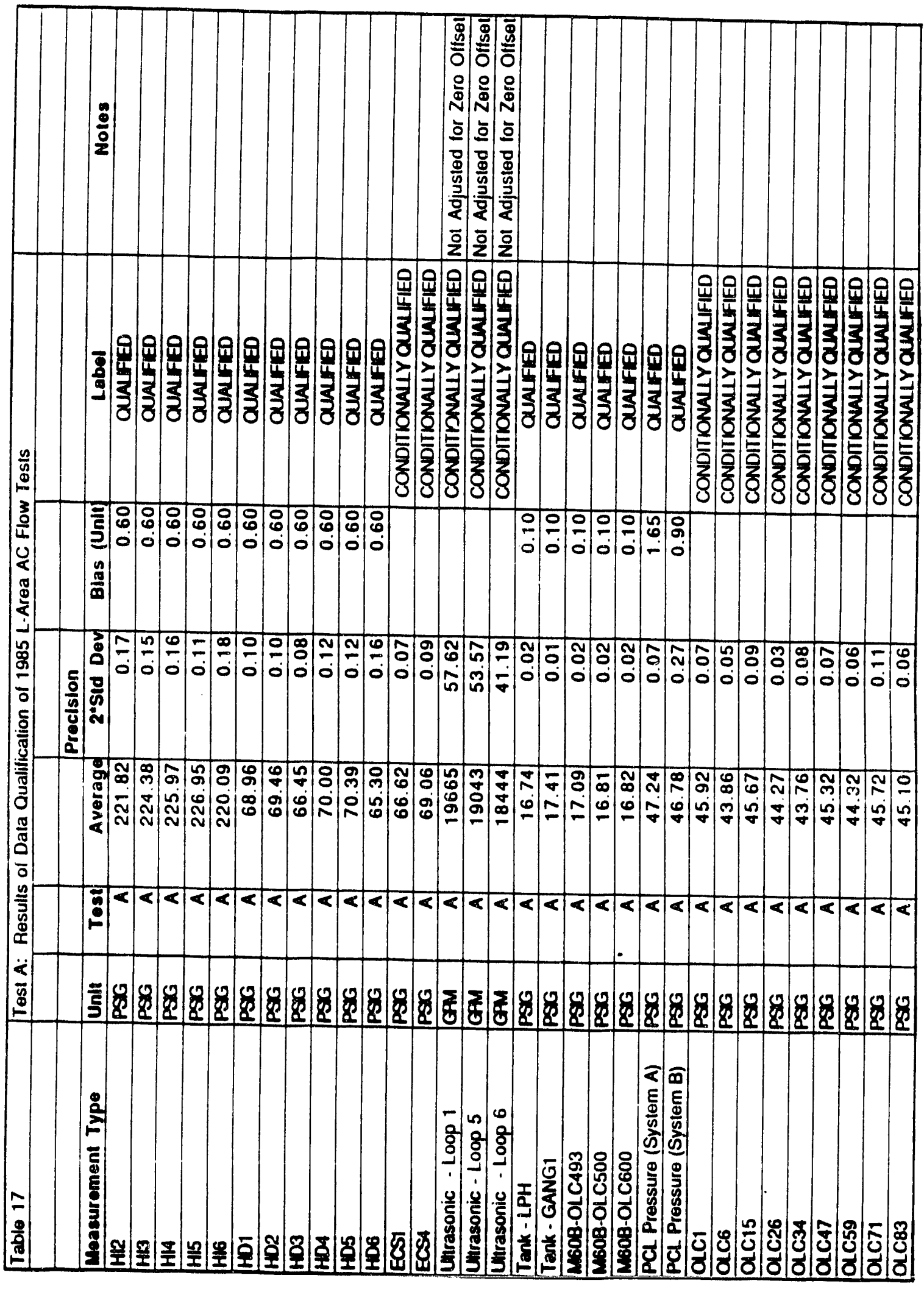


Task 91-033-1

DQ Summary for 1985 L-Area AC Flow Tests

Revision 0

Page 67 of 119

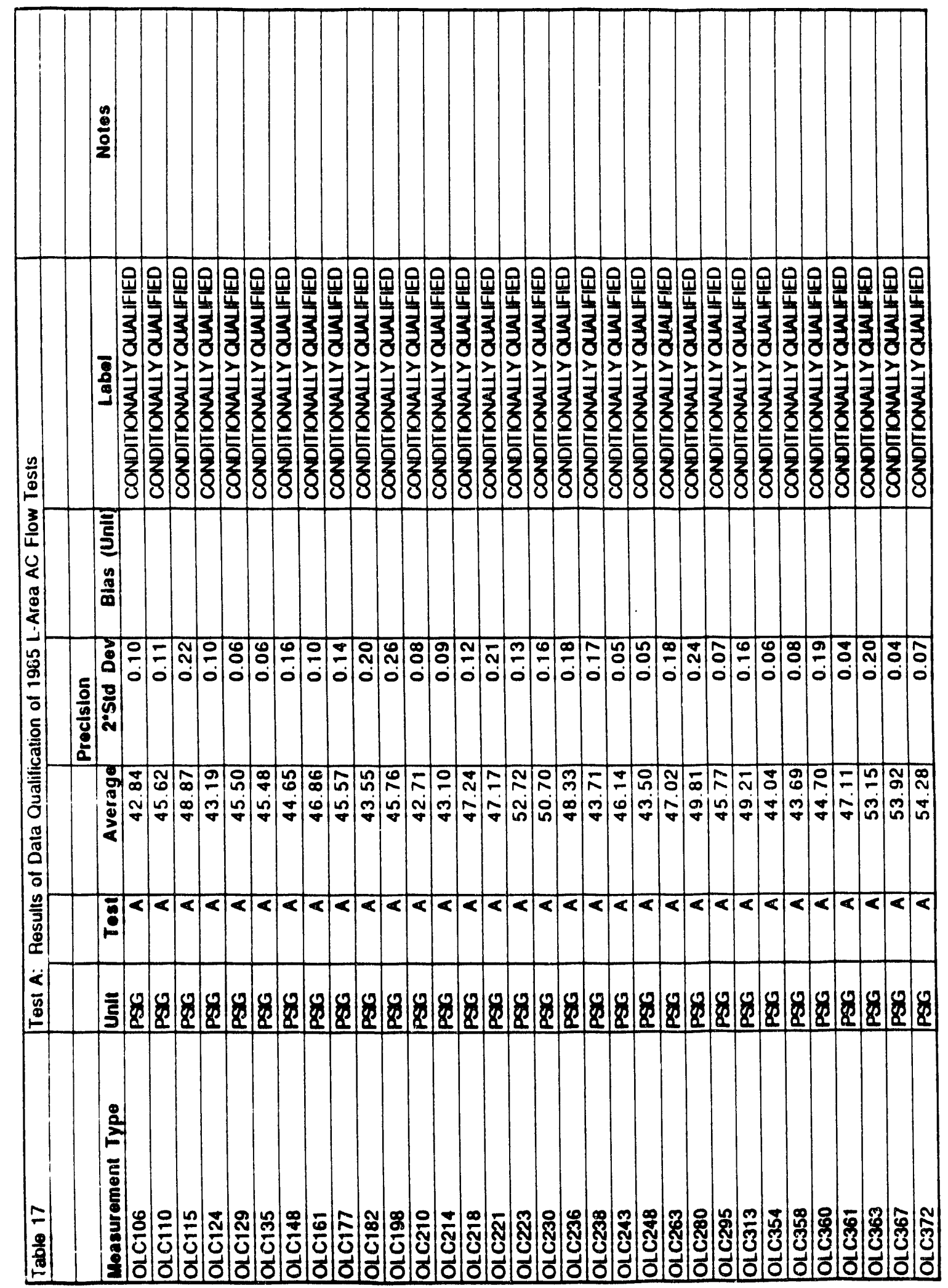


WSRC-TR-92-134

Task 91-033-1

DQ Summary for 1985 L-Area AC Flow Tests

March 10, 1992

Revision 0

Page 68 of 119

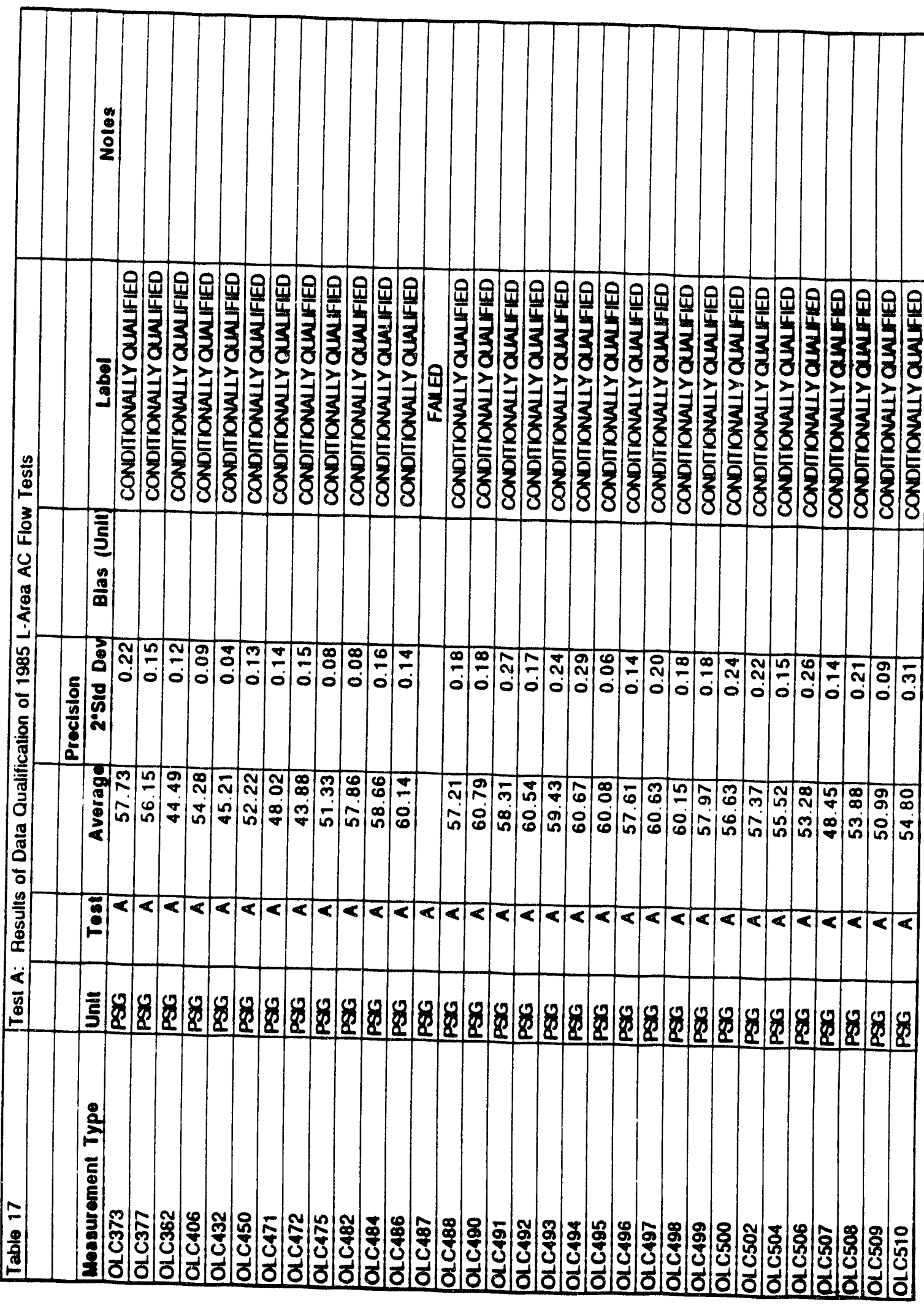




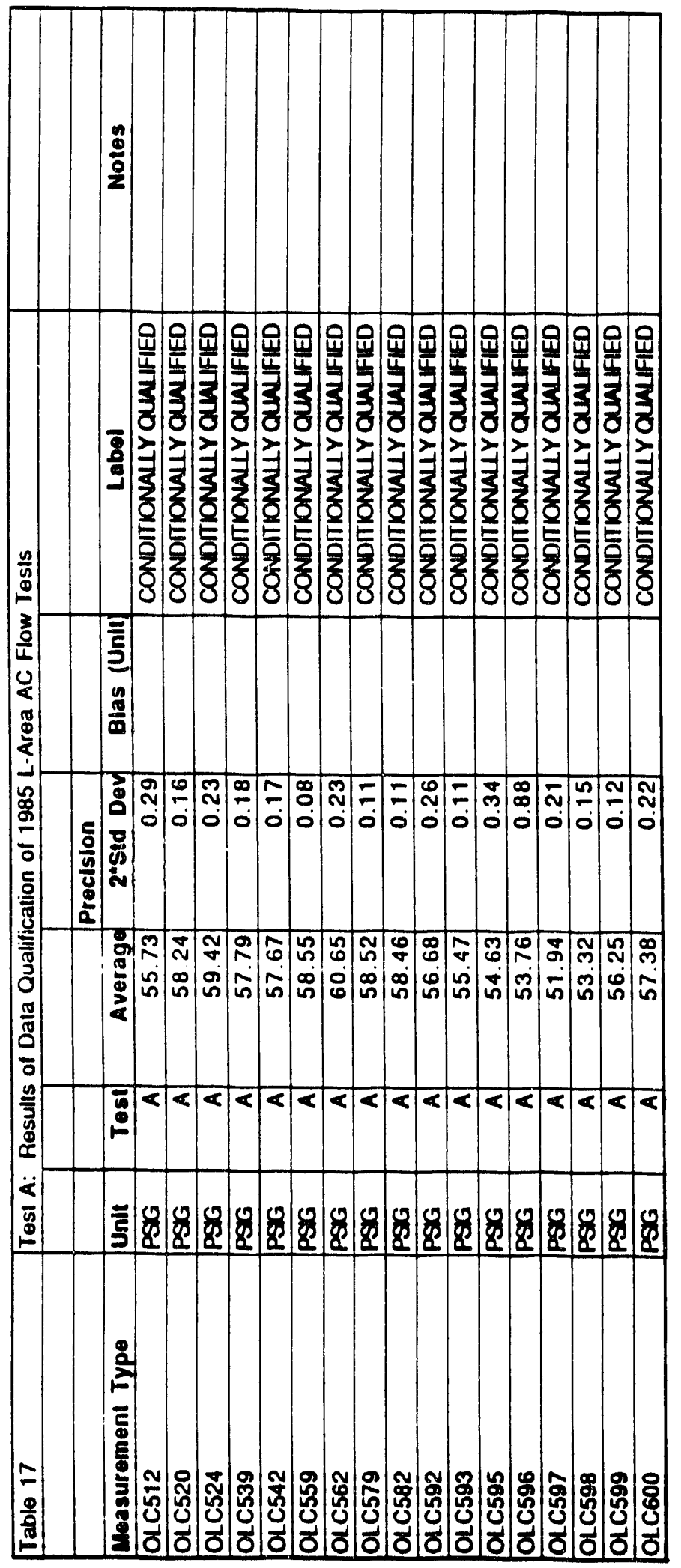


WSRC-TR-92-134

Task 91-033-1

- DQ Summary for 1985 L-Area AC Flow Tests

March 10, 1992

Revision 0

Page 71 of 119

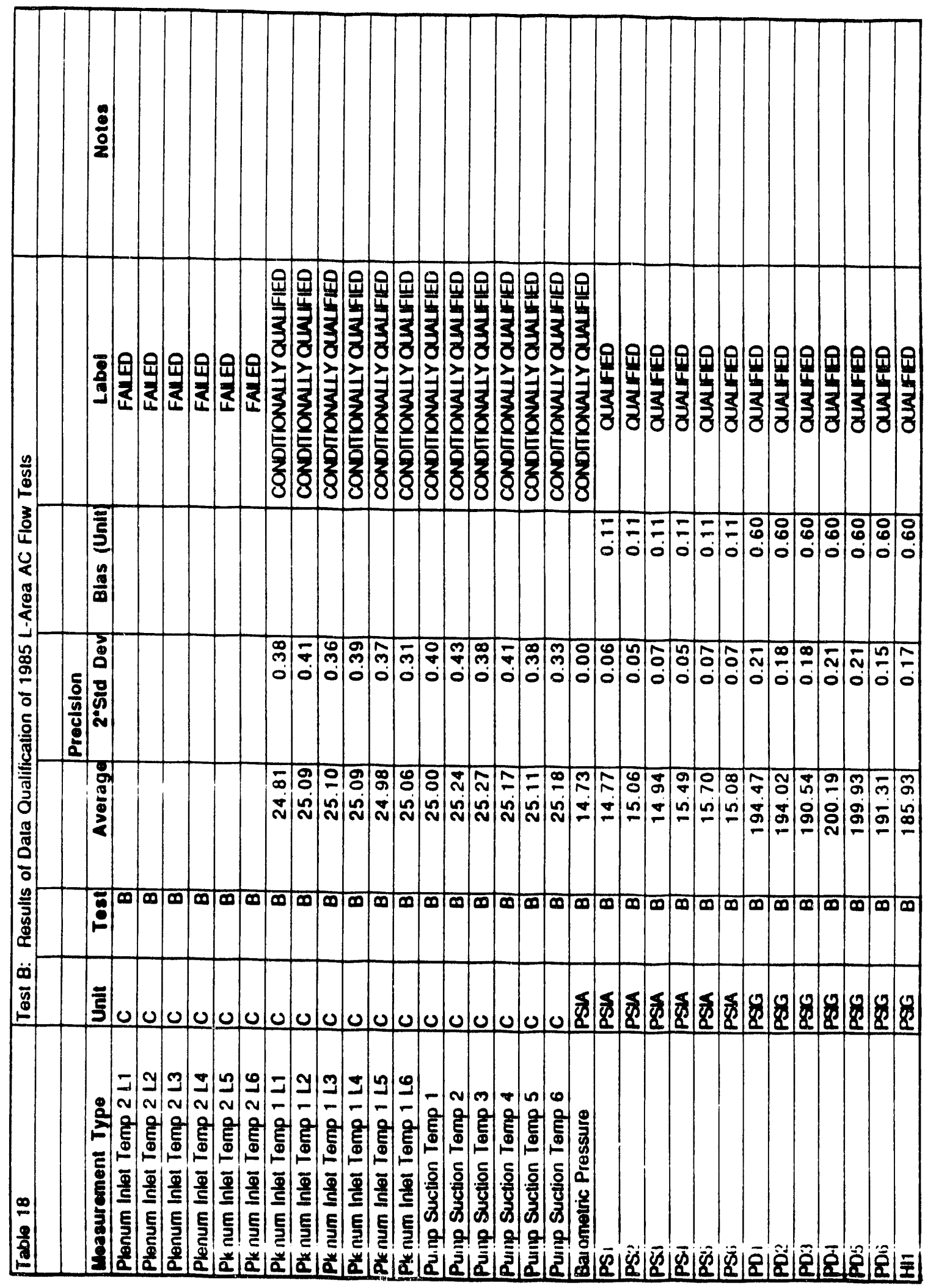




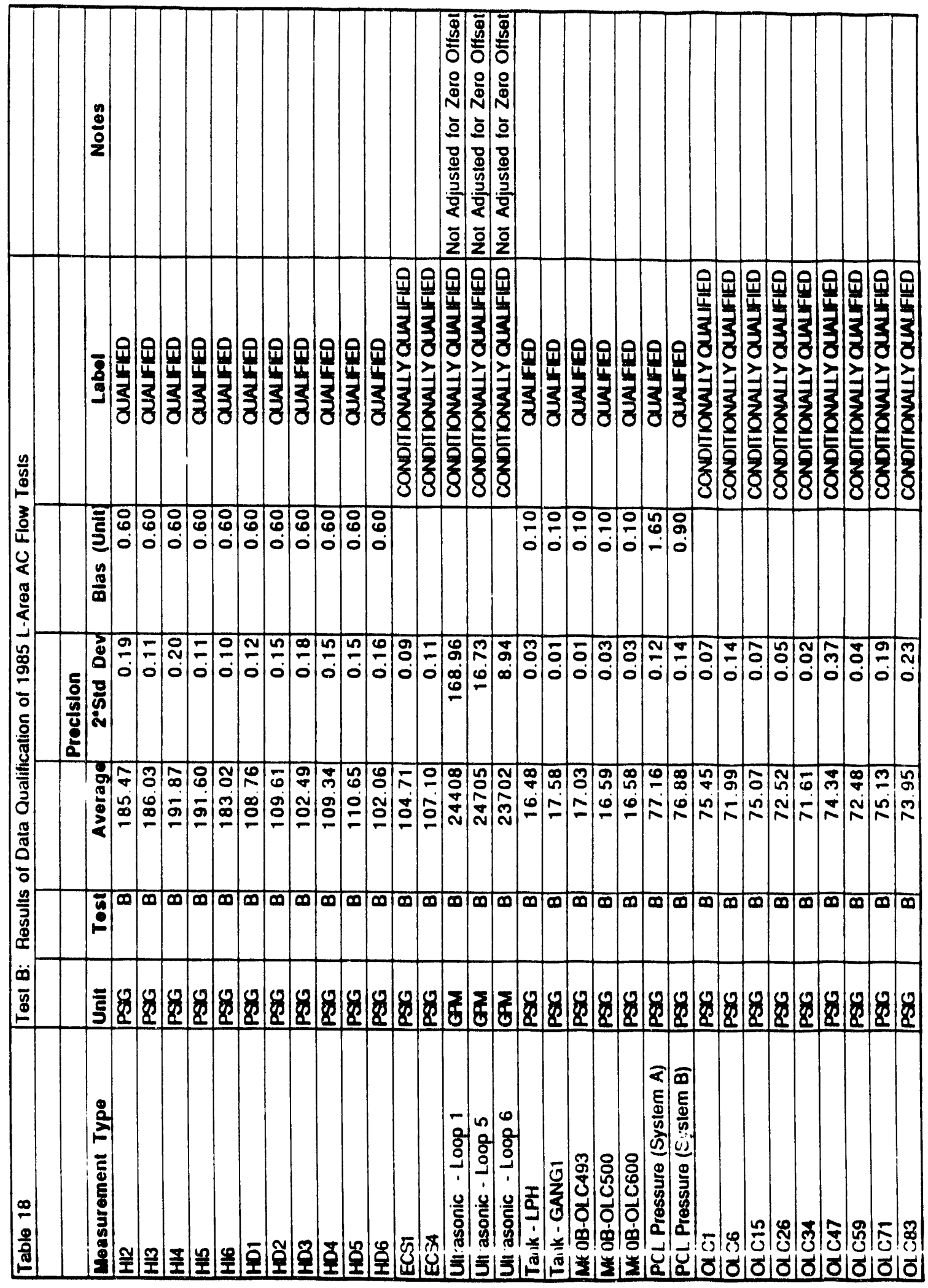




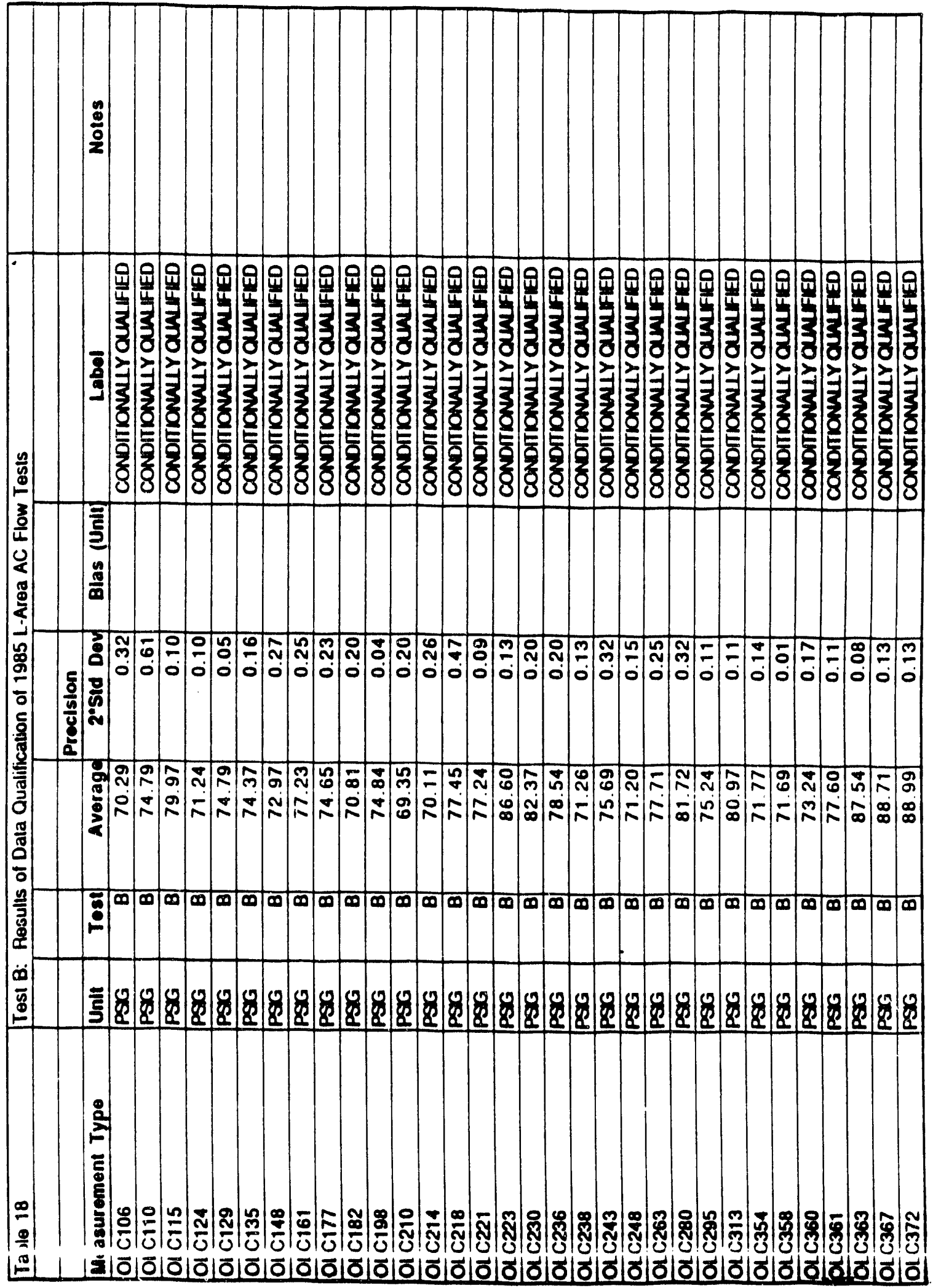




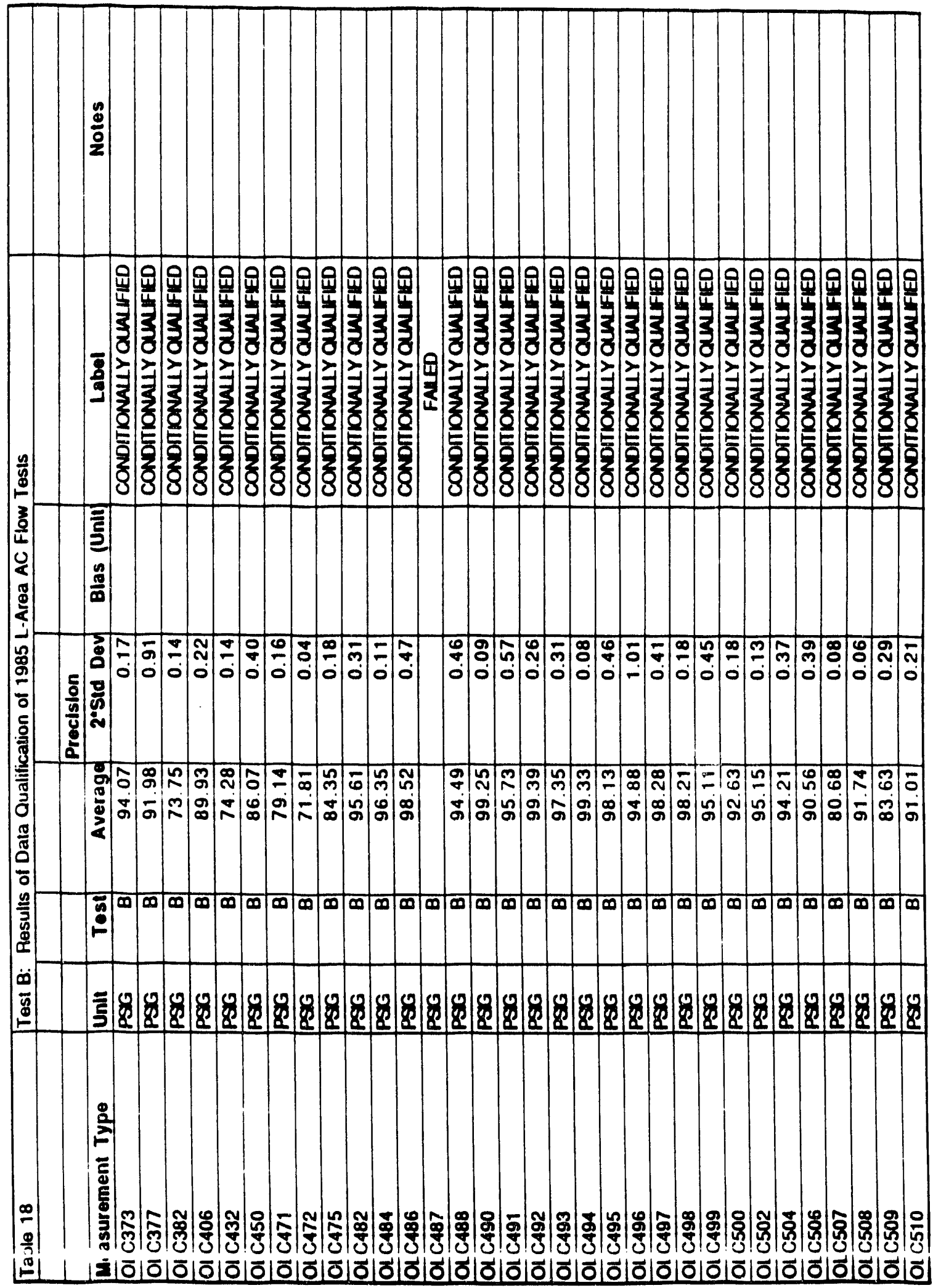




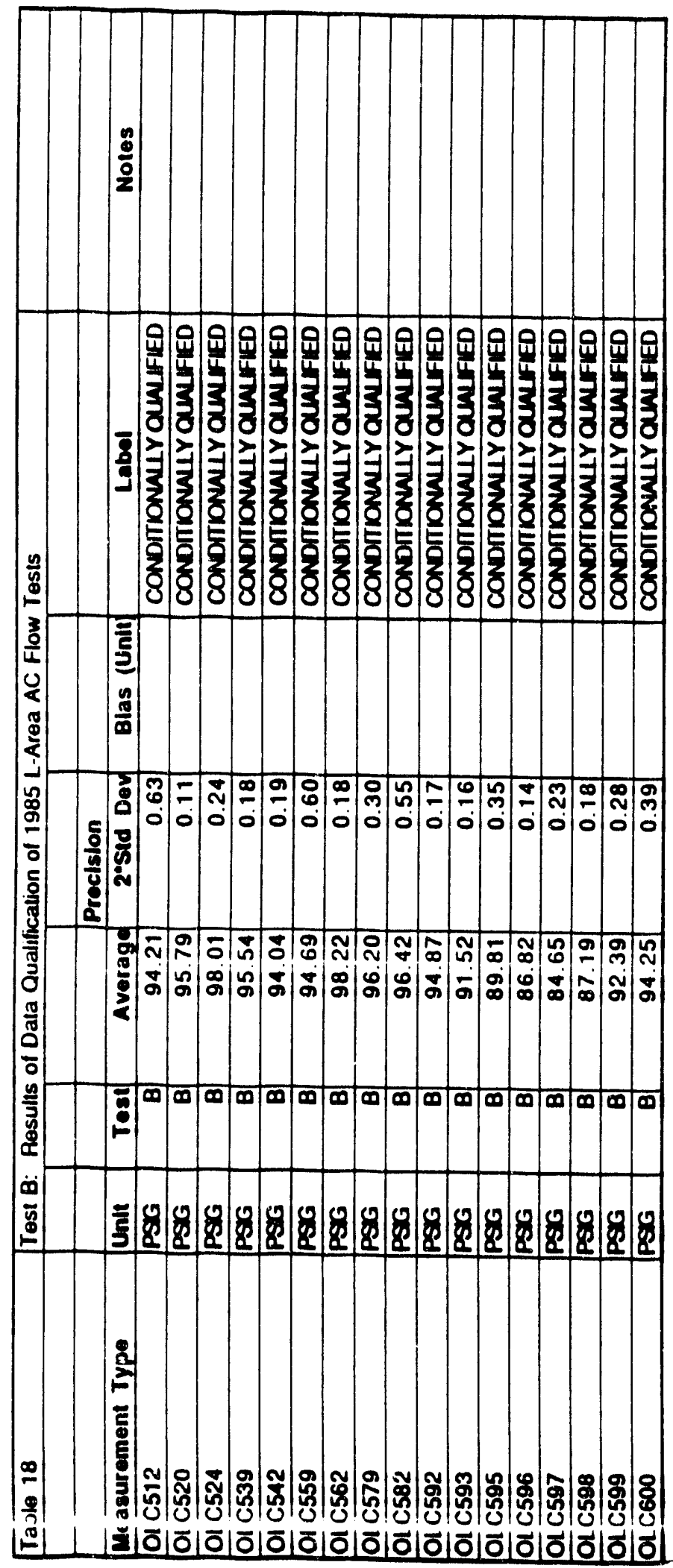




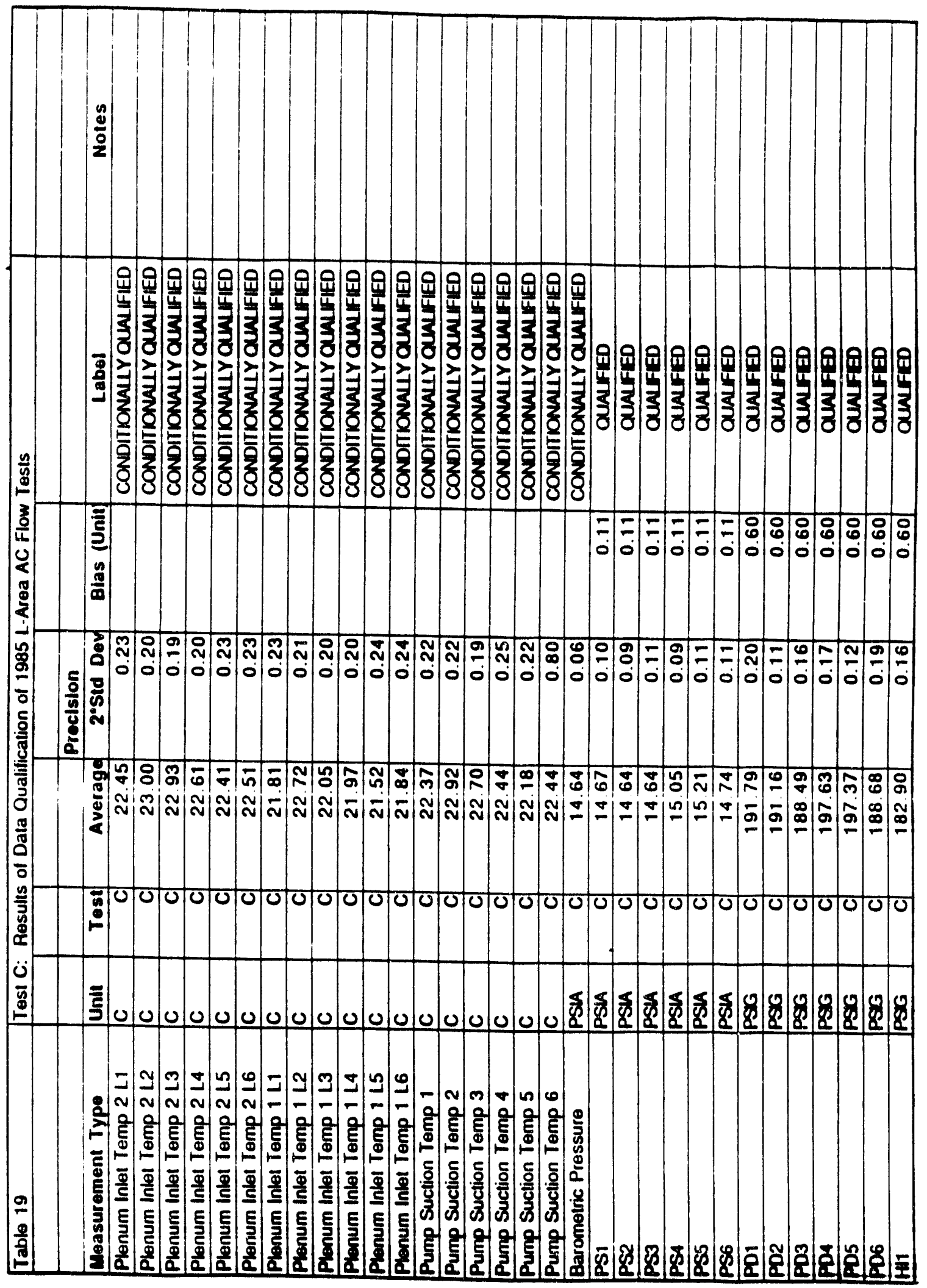


WSAC-TR-92-134

Task 91-033-1

DQ Summary for 1985 L-Area AC Flow Tests
March 10, 1992

Revision 0

Page 76 of 119

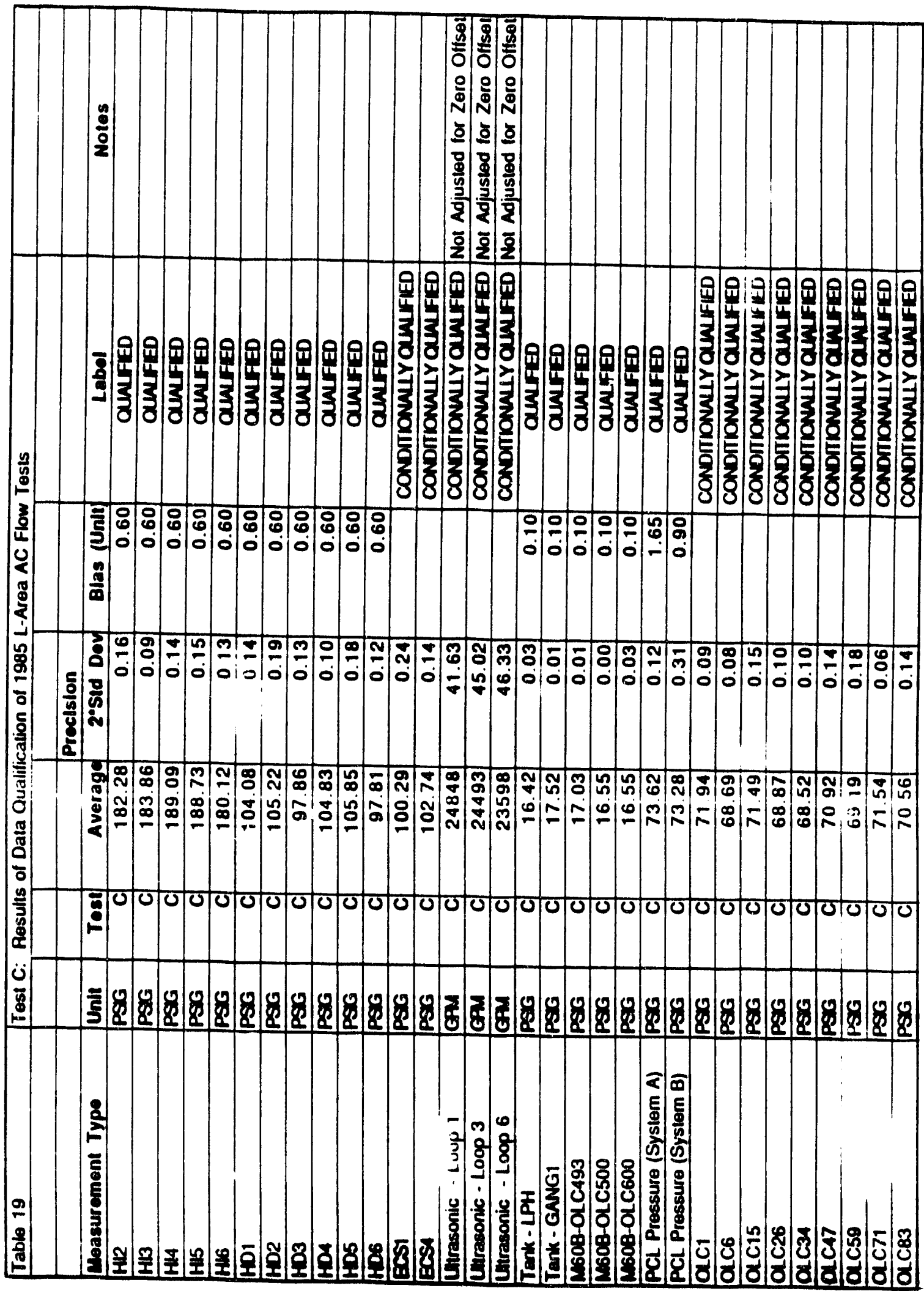




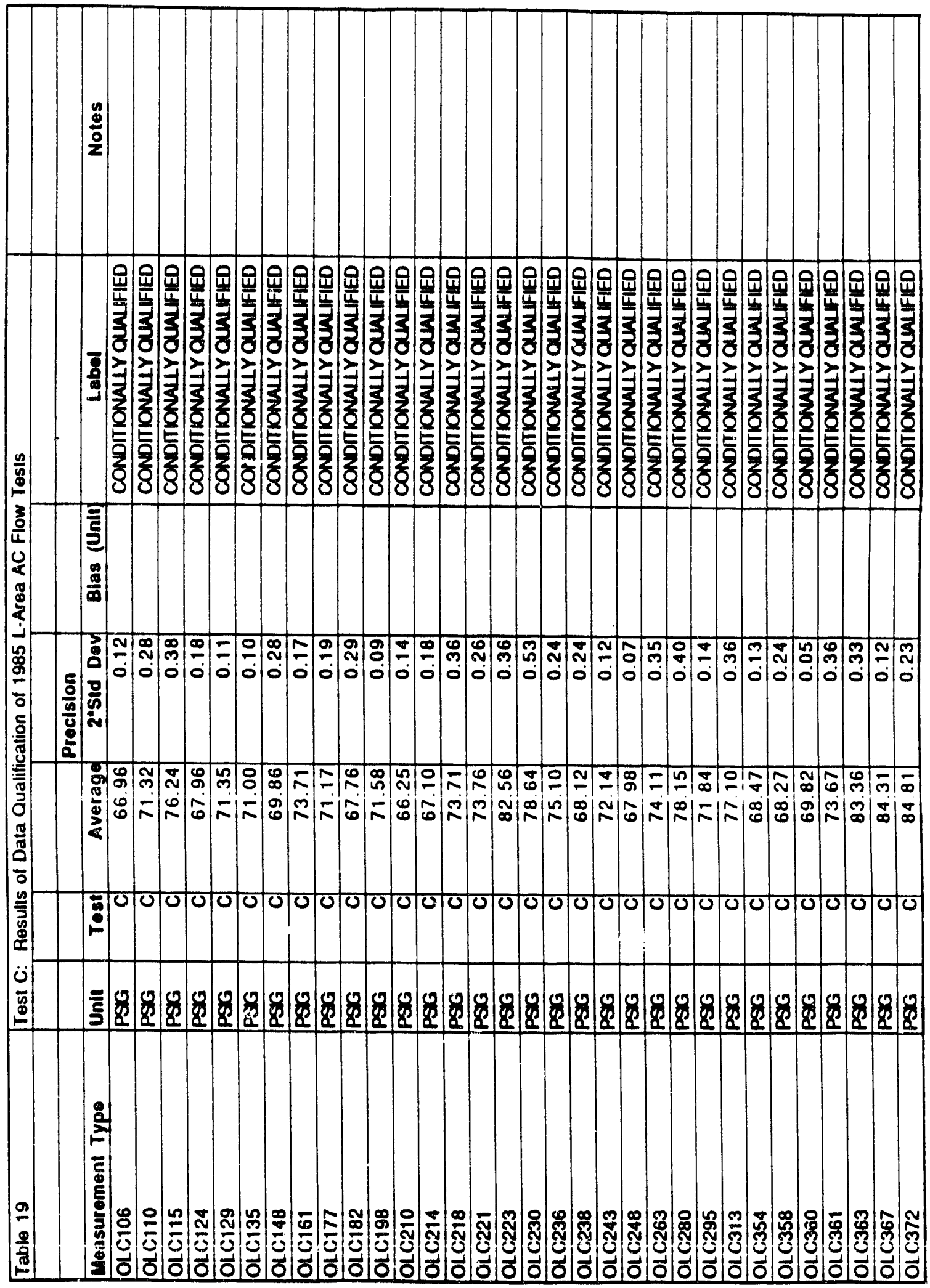


WSRC-TR-92-134

Task 91-033-1

DQ Summary for 1985 L-Area AC Flow Tests
March 10, 1992

Revision 0

Page 78 of 119

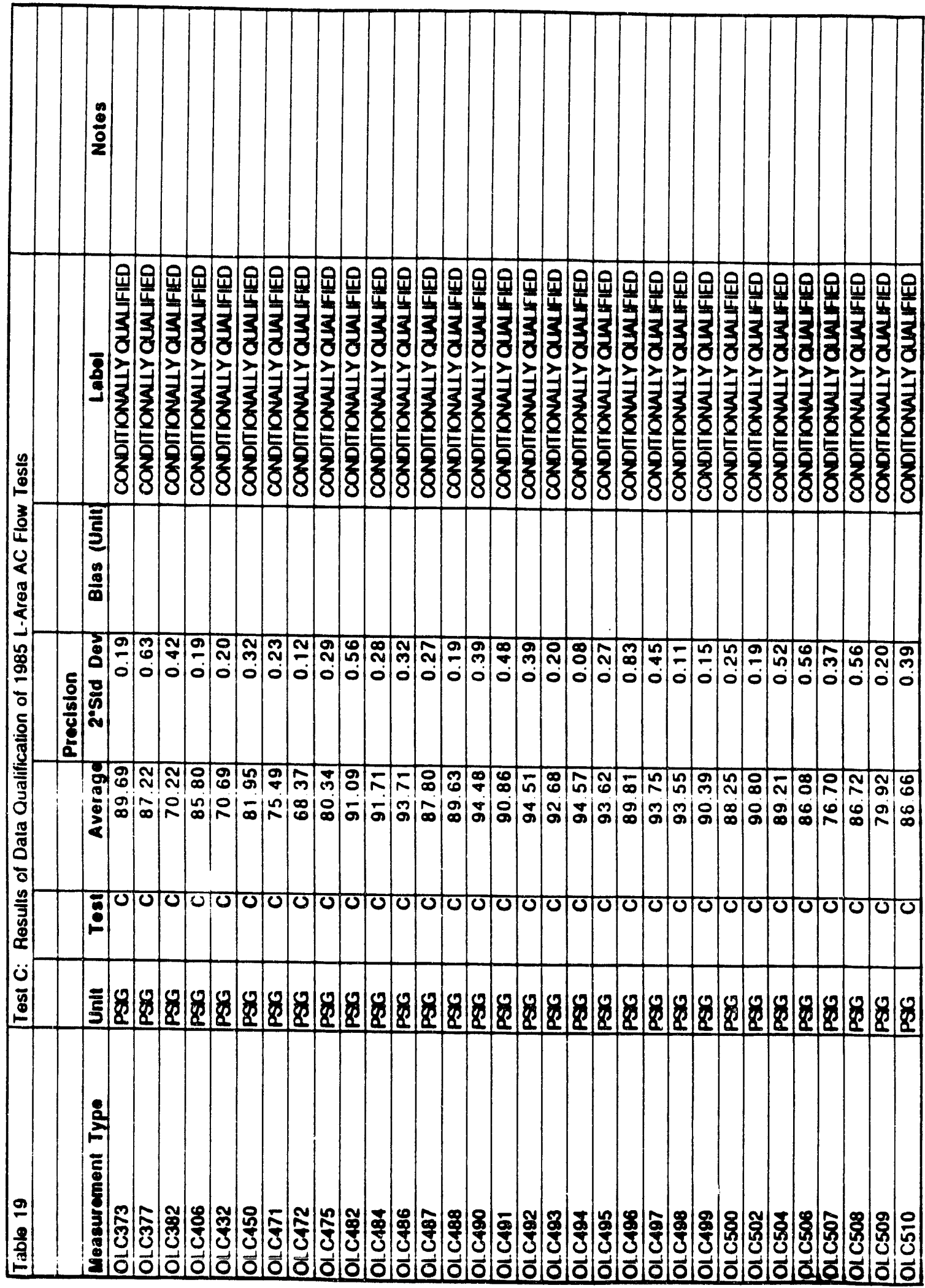




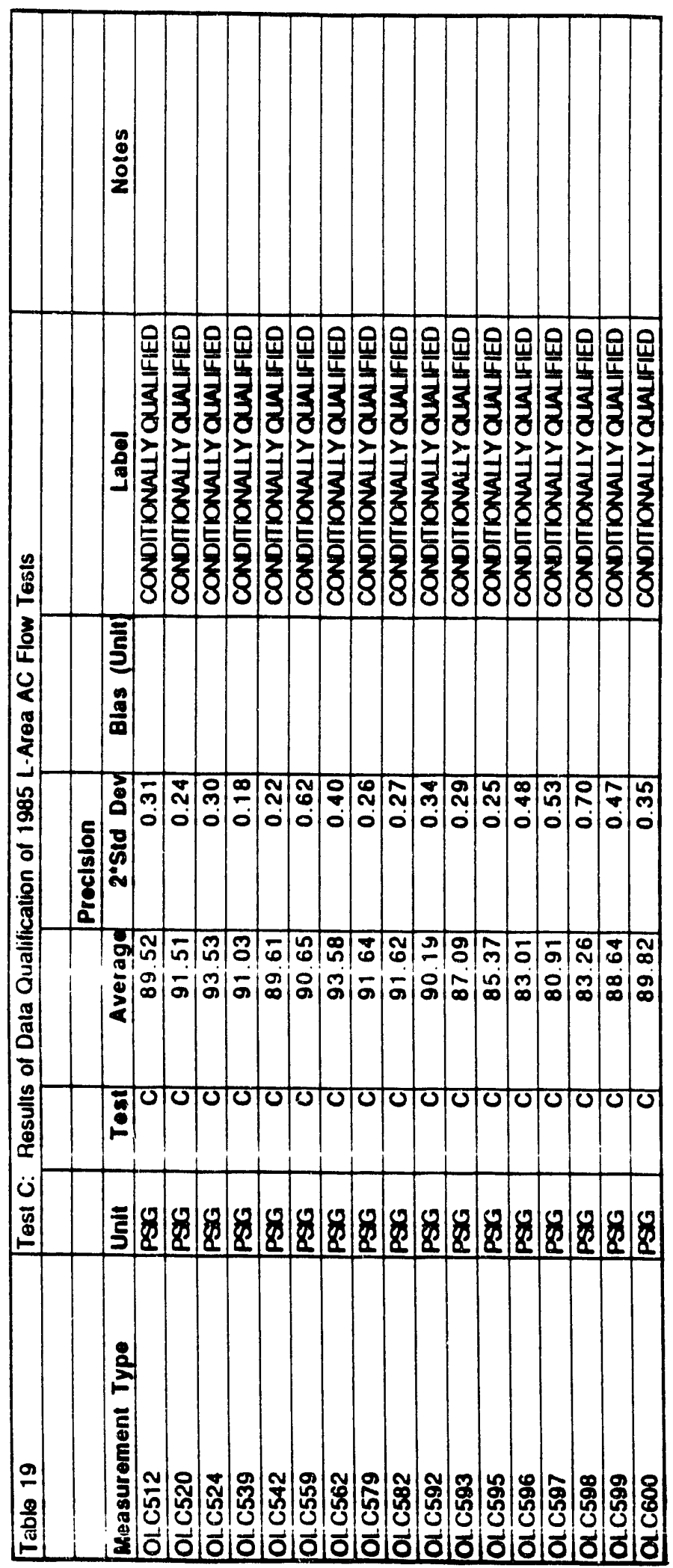




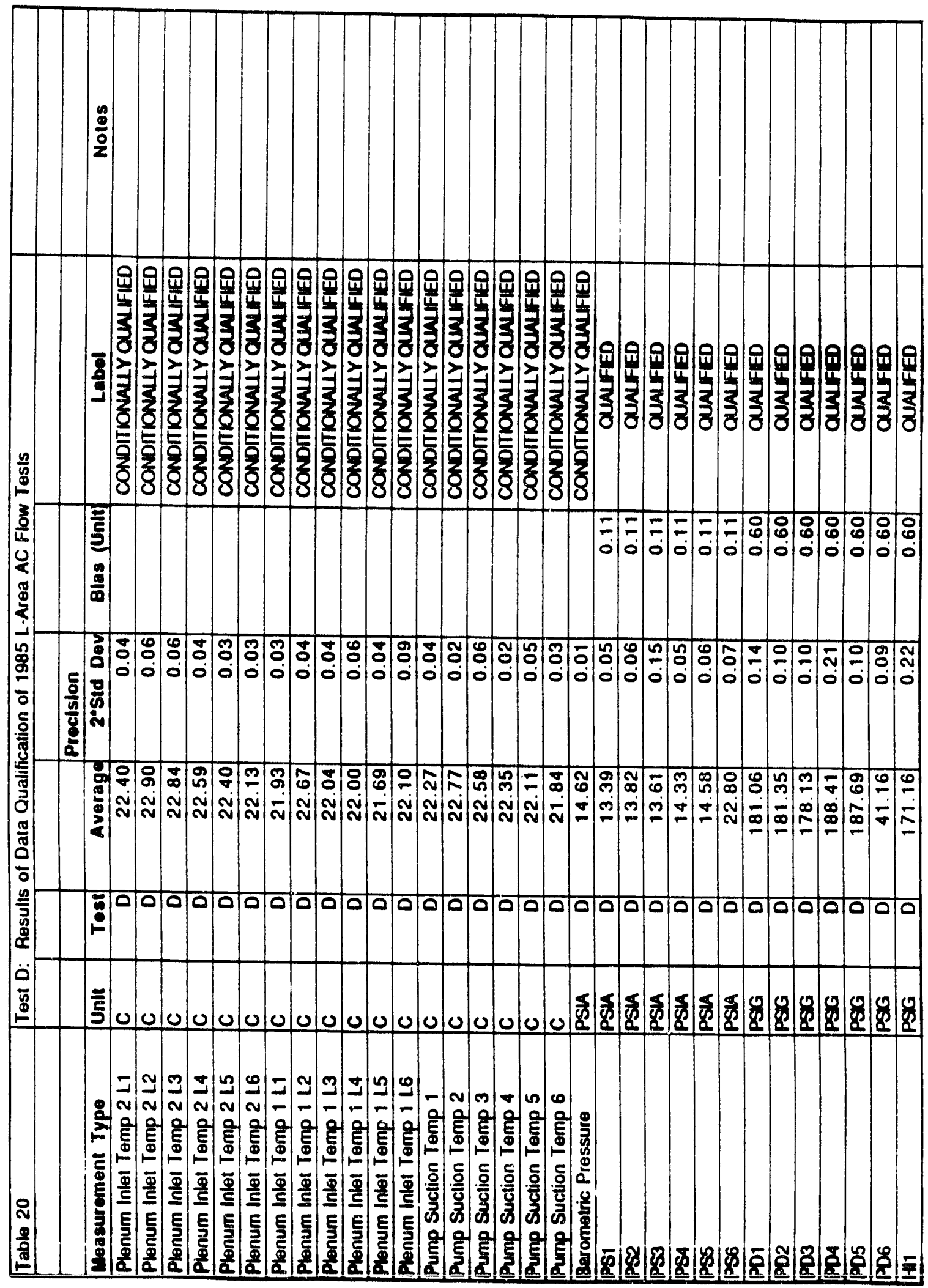




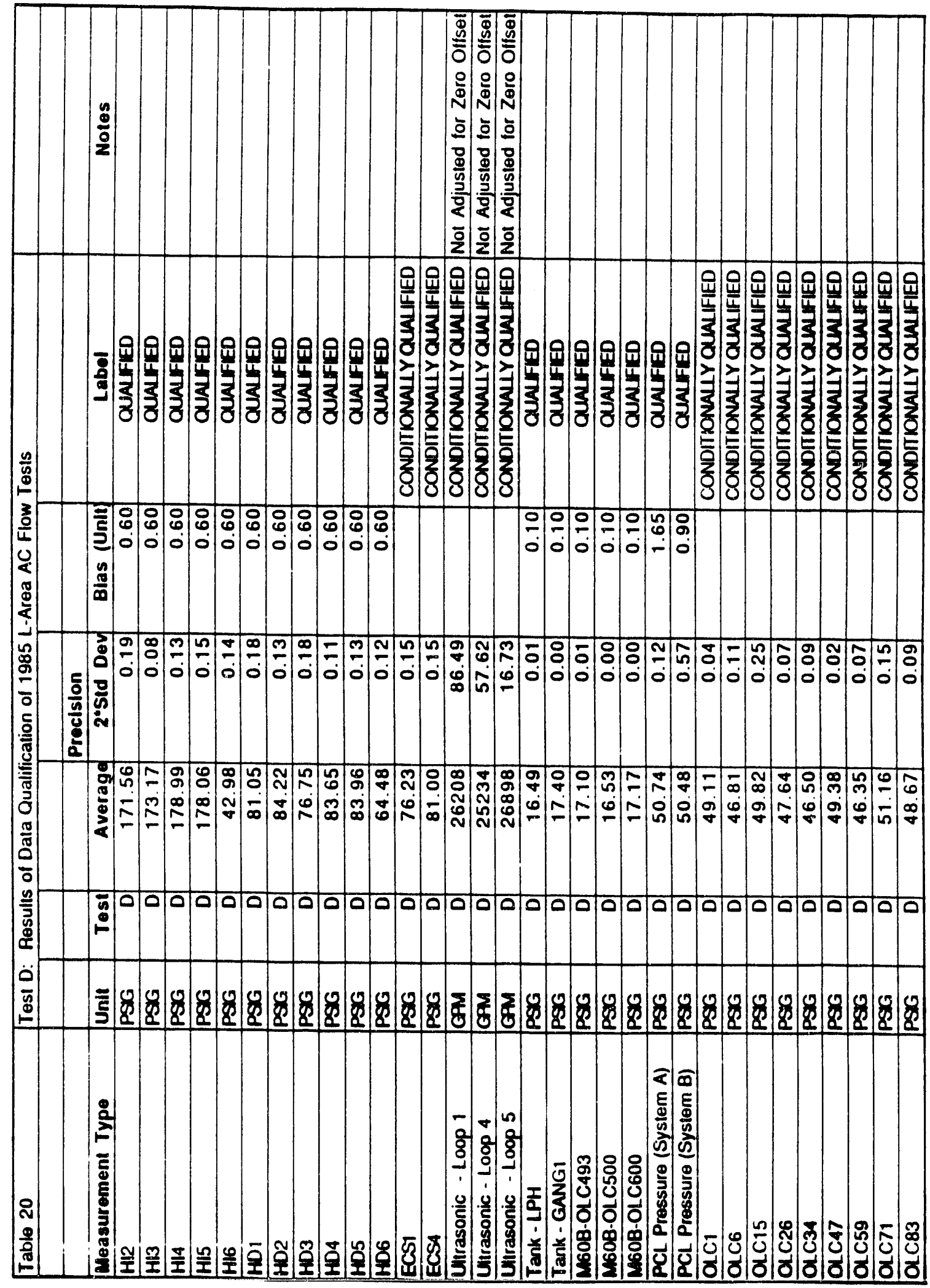




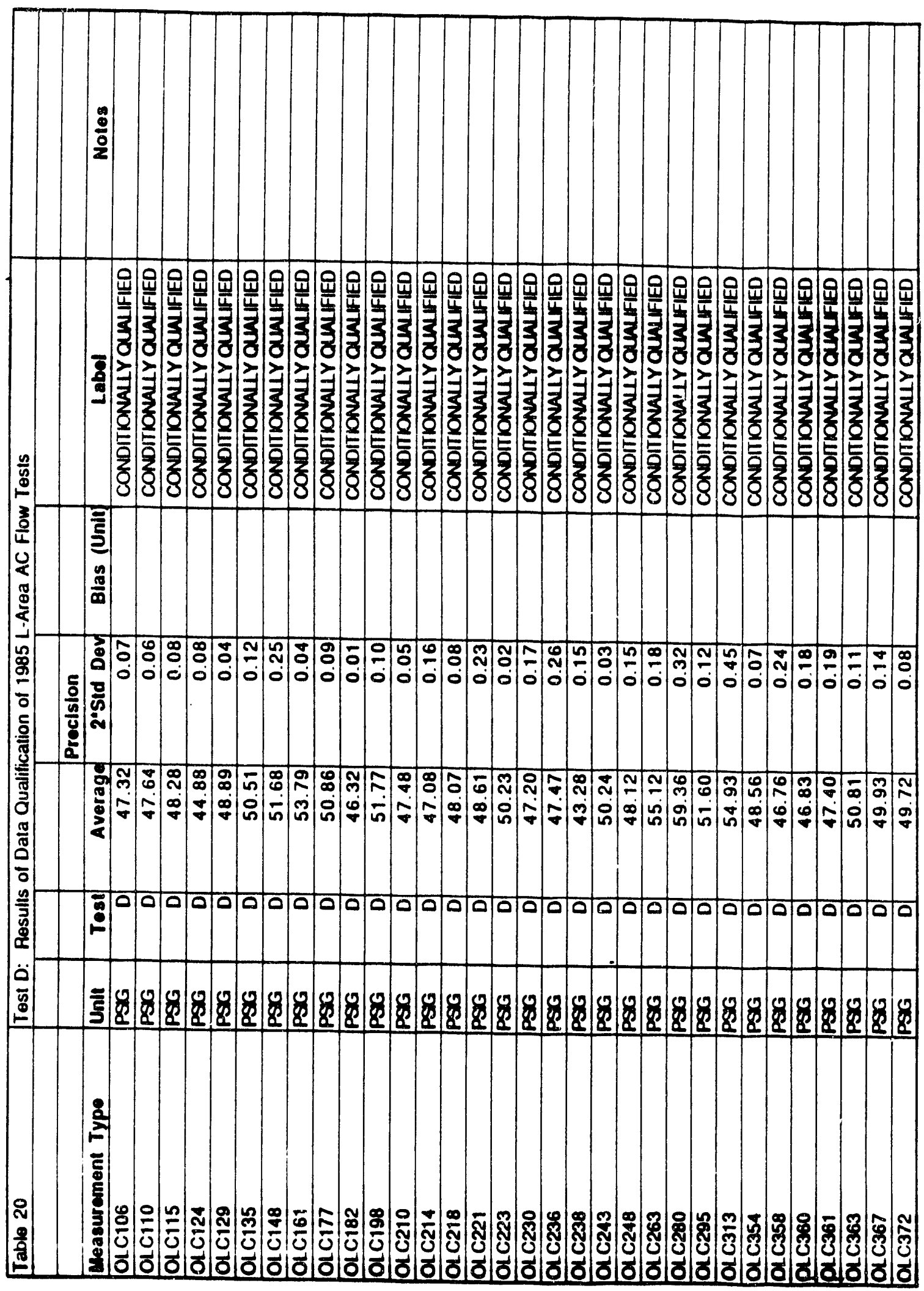




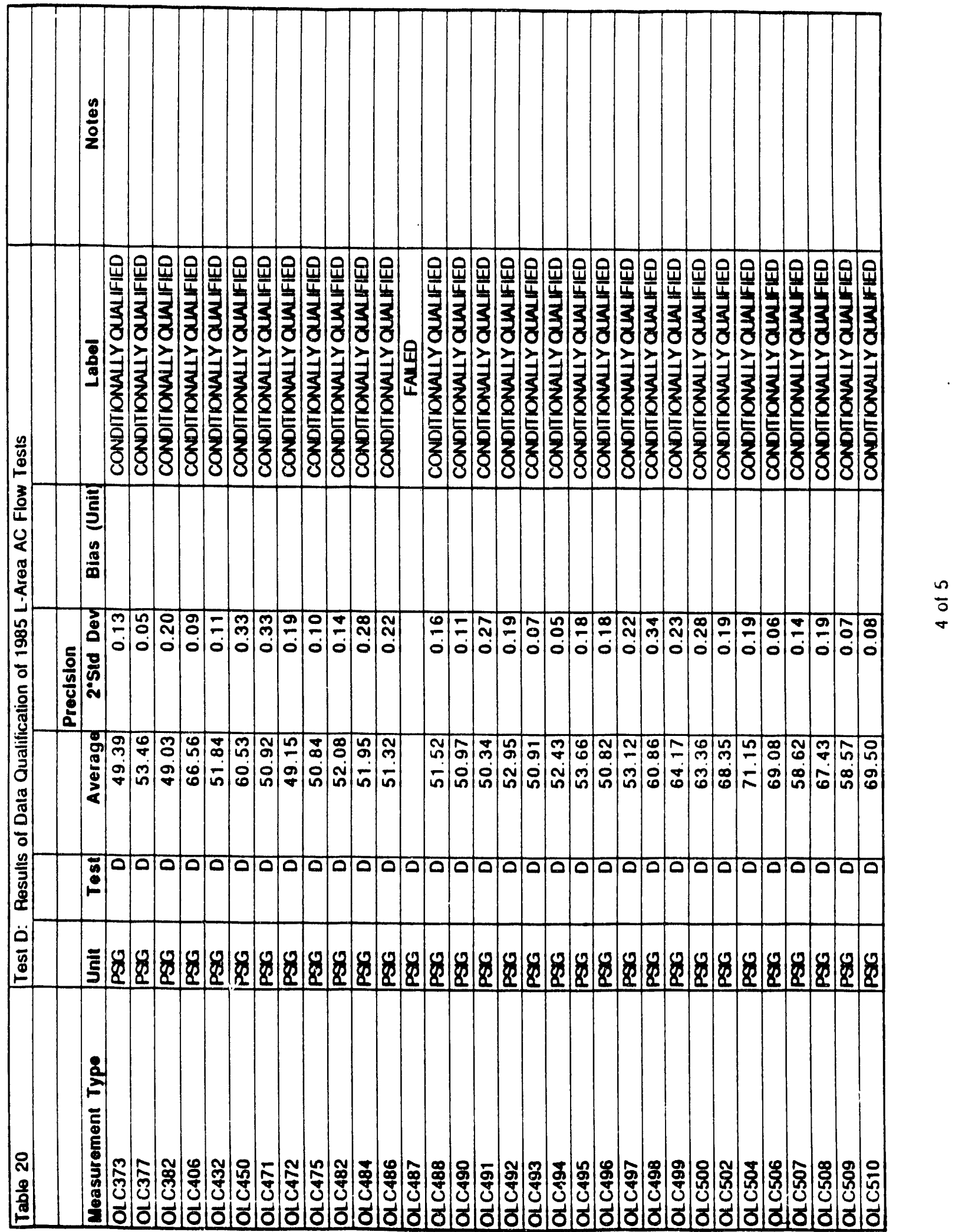




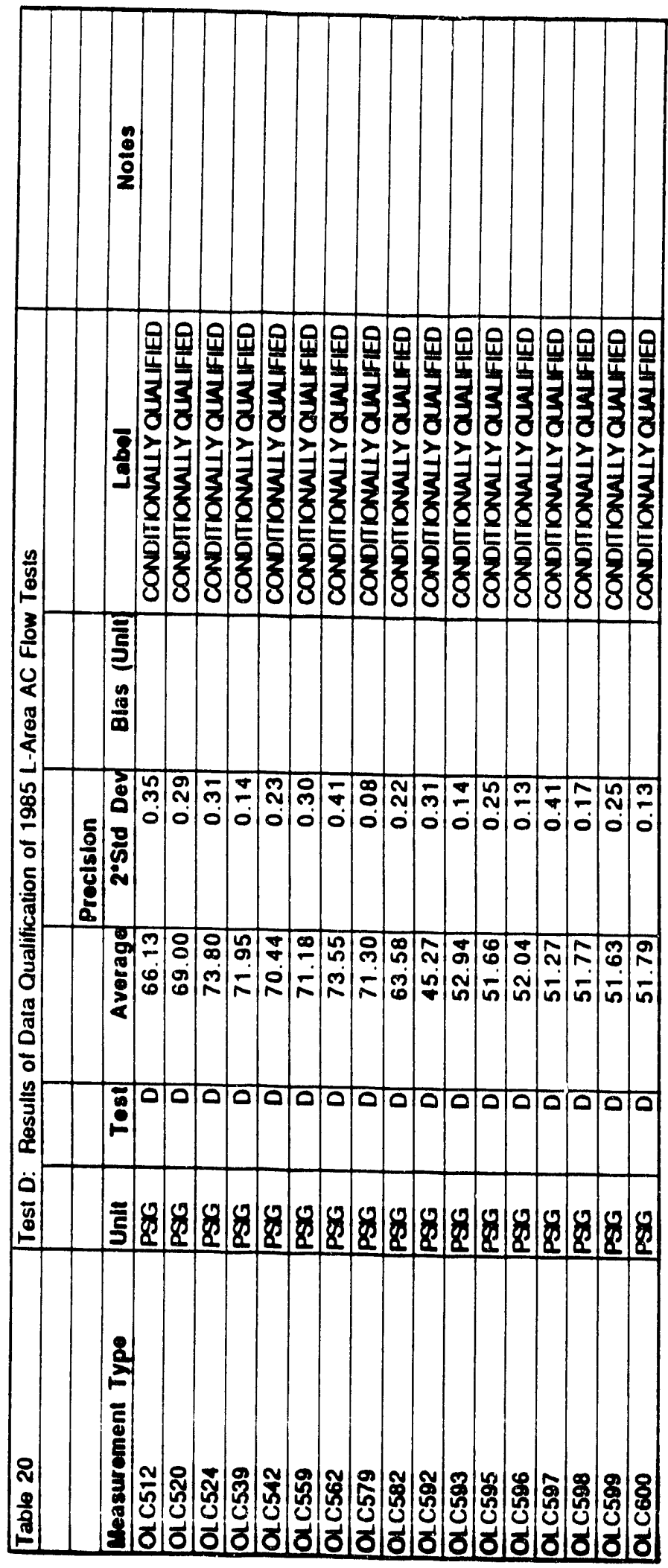




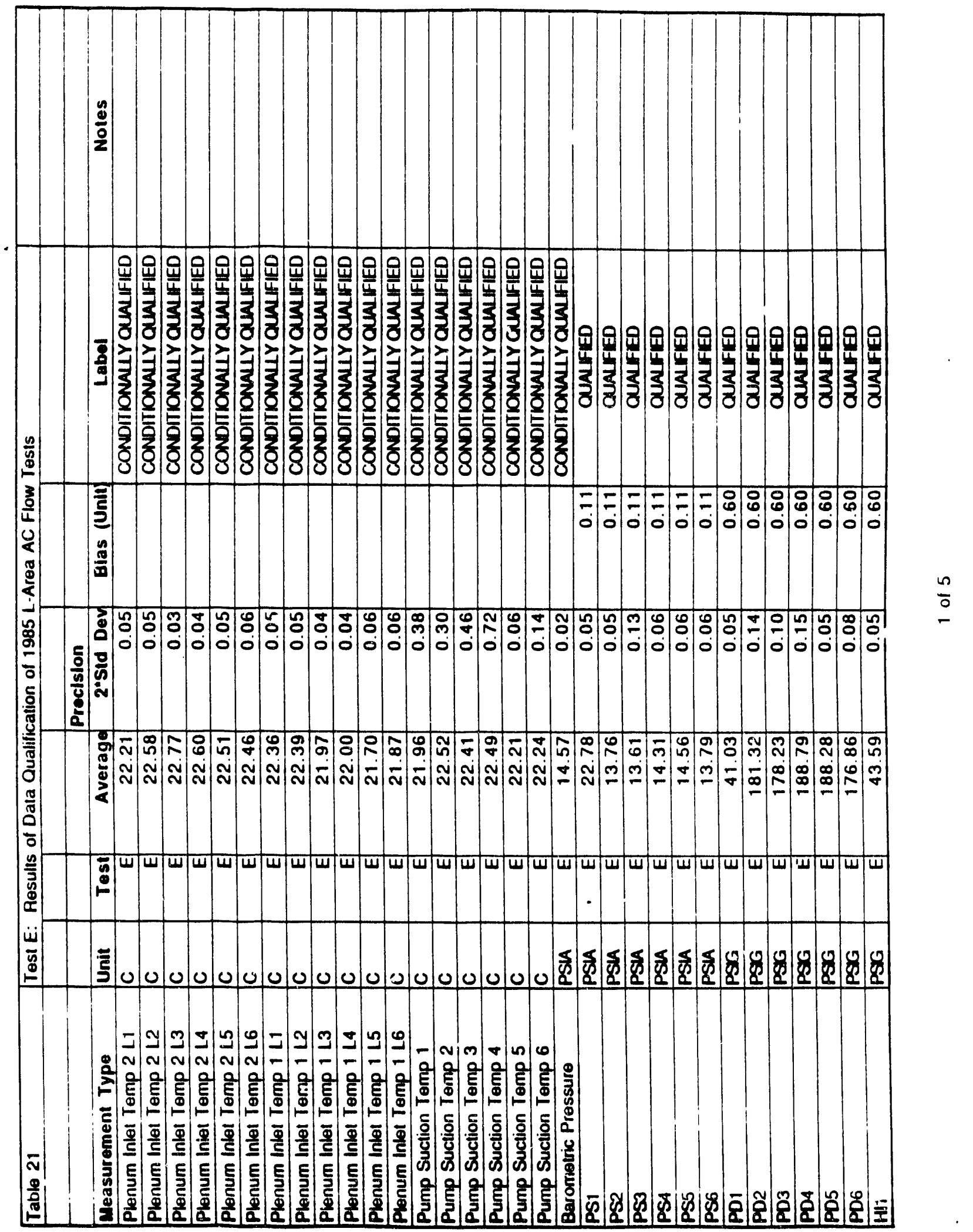


WSRC-TR-92-134

March 10, 1992

Task 91-033-1

DQ Summary for 1985 L-Area AC Flow Tests

Revision 0

Page 86 of 119

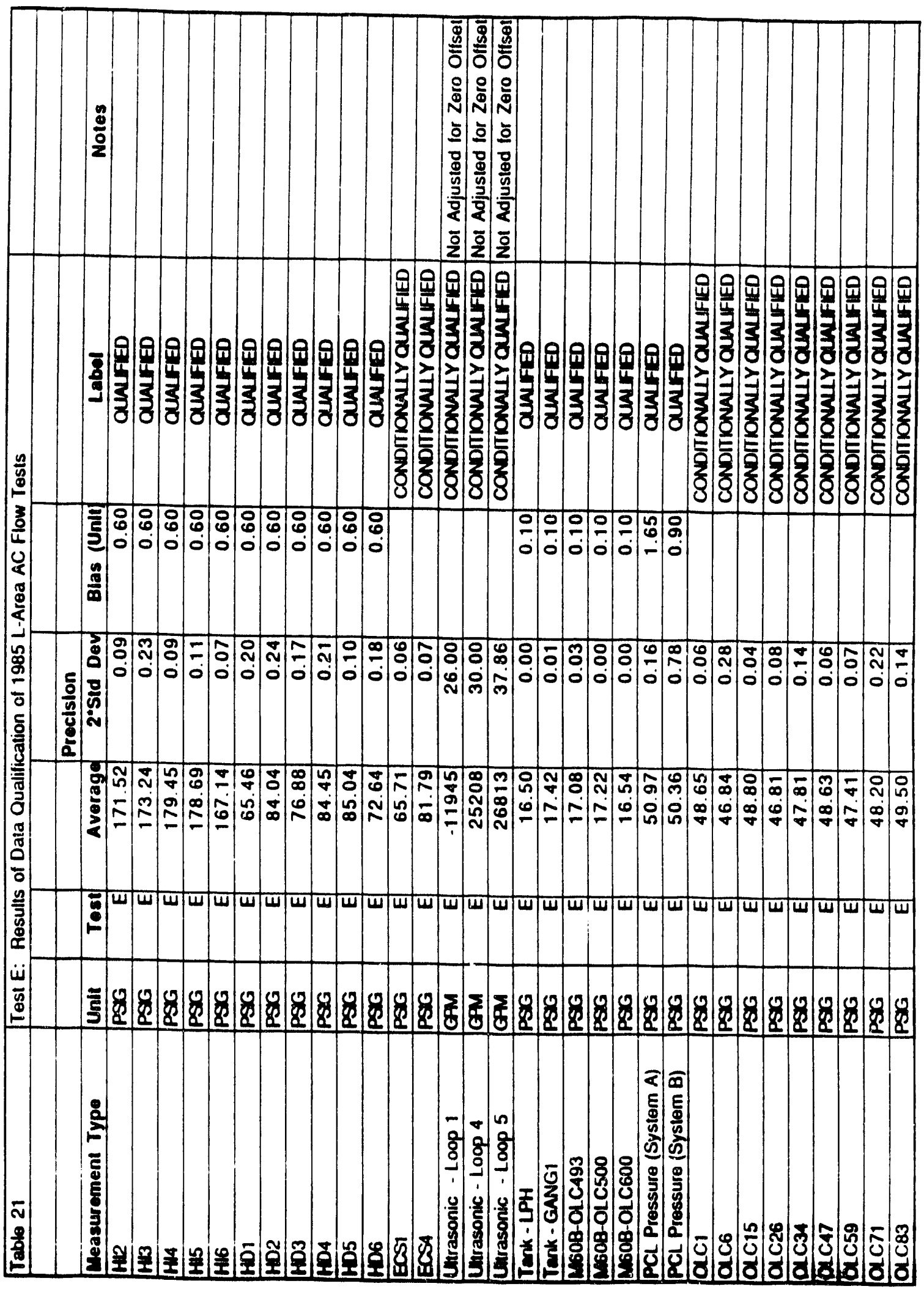


WSRC-TR-92-134

Task 91-033-1

DQ Summary for 1985 L-Area AC Flow Tests
March 10, 1992

Revision 0

Page 87 of 119

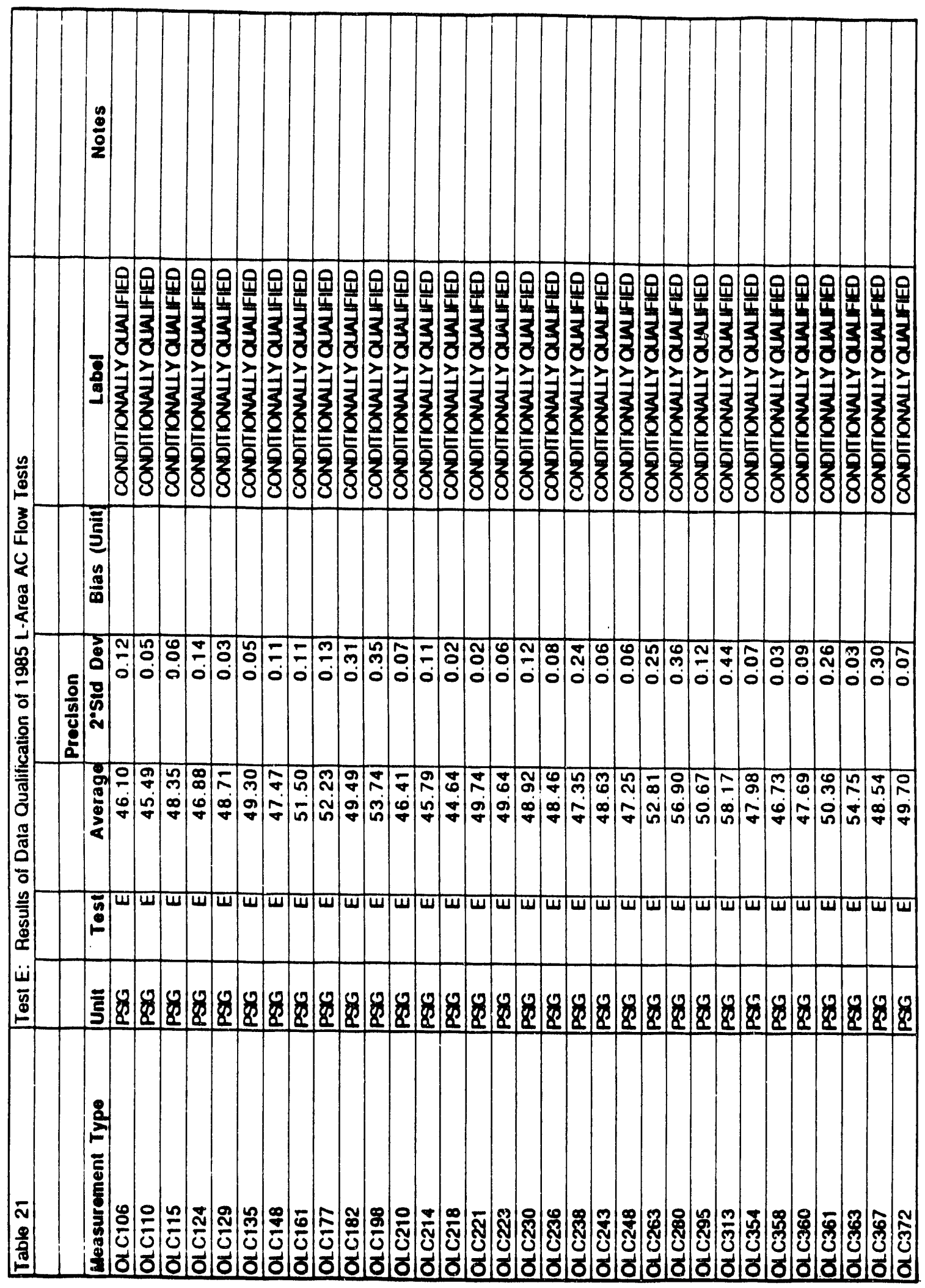


WSRC-TR-92-134

Task 91-033-1

DQ Summary for 1985 L-Area AC Flow Tests
March 10, 1992

Revision 0

Page 88 of 119

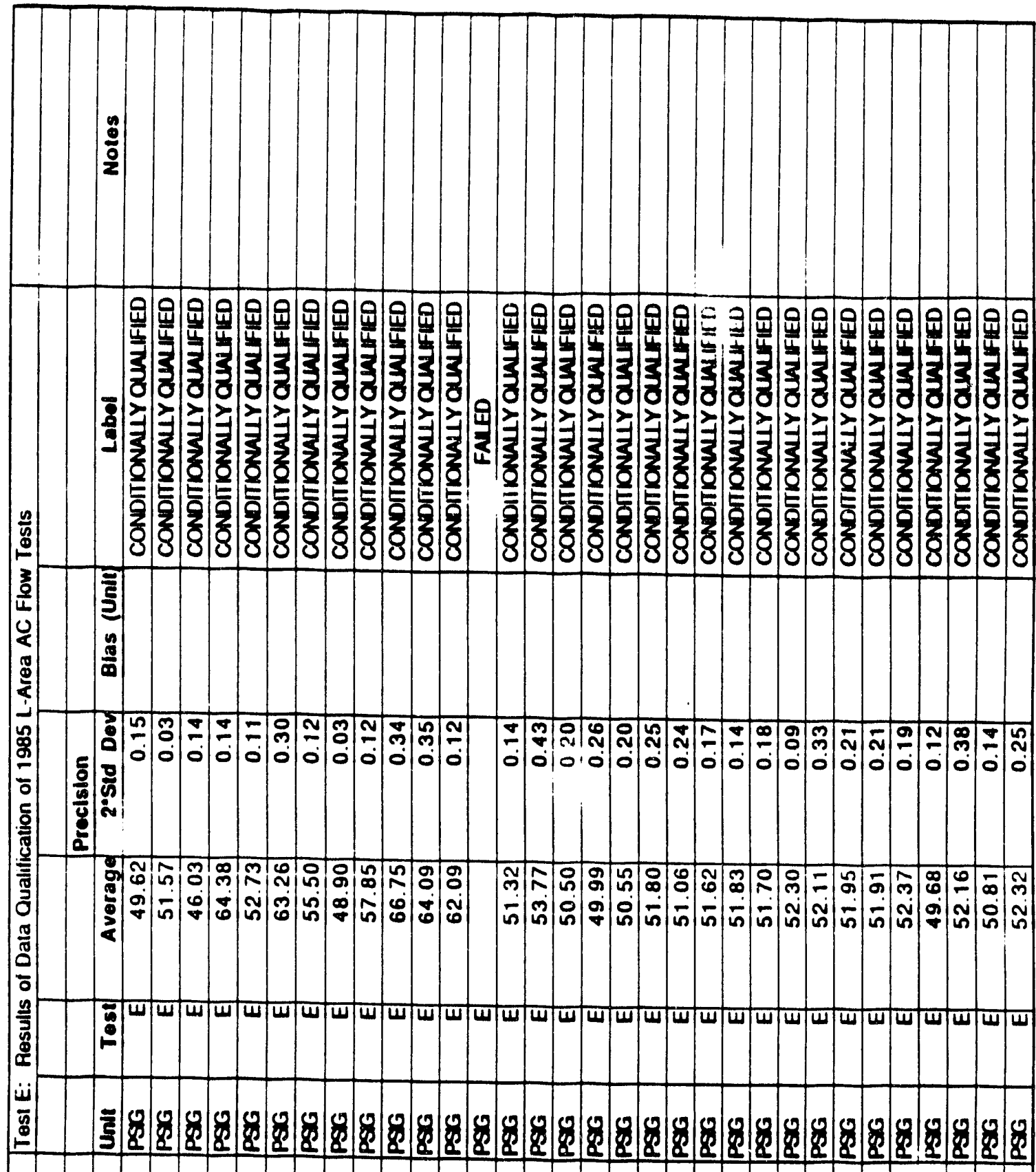

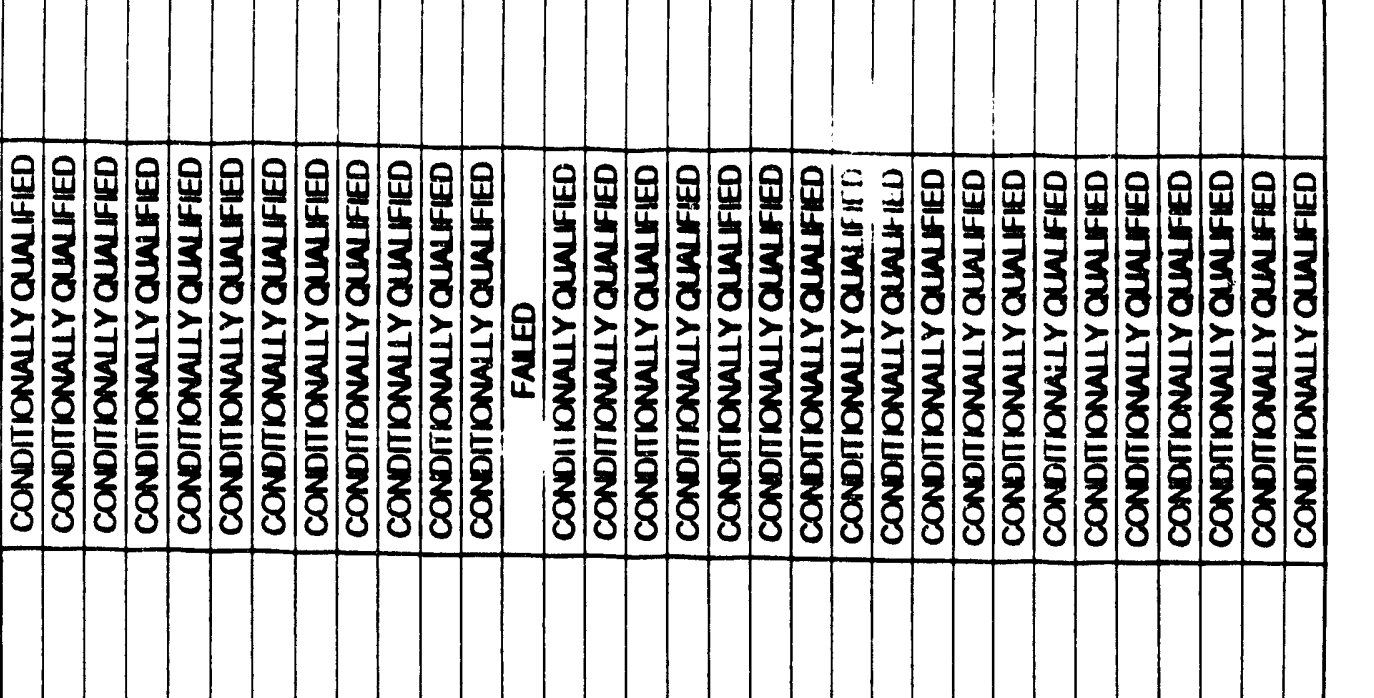

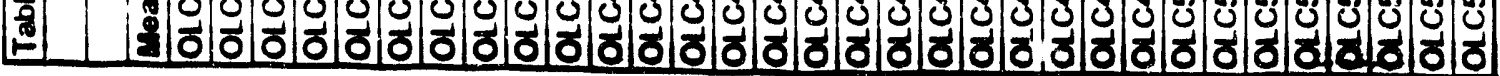




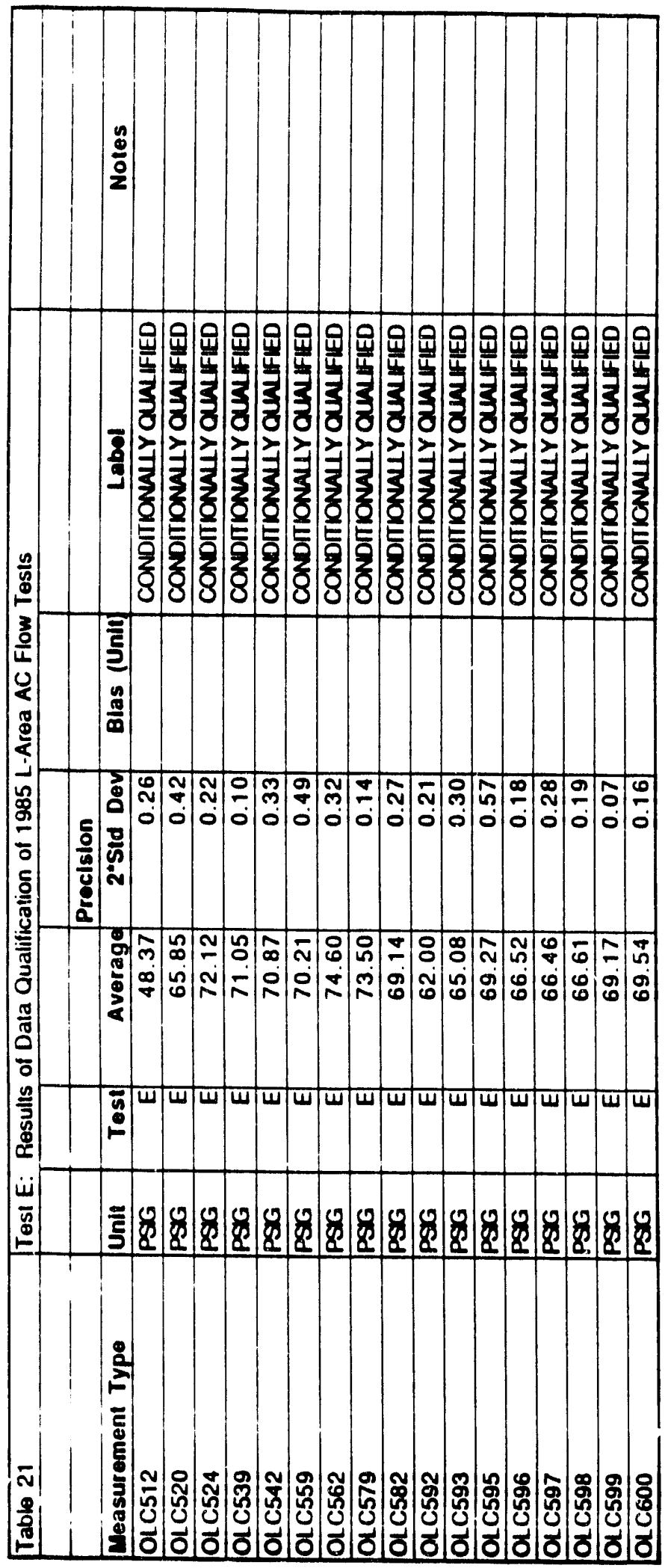




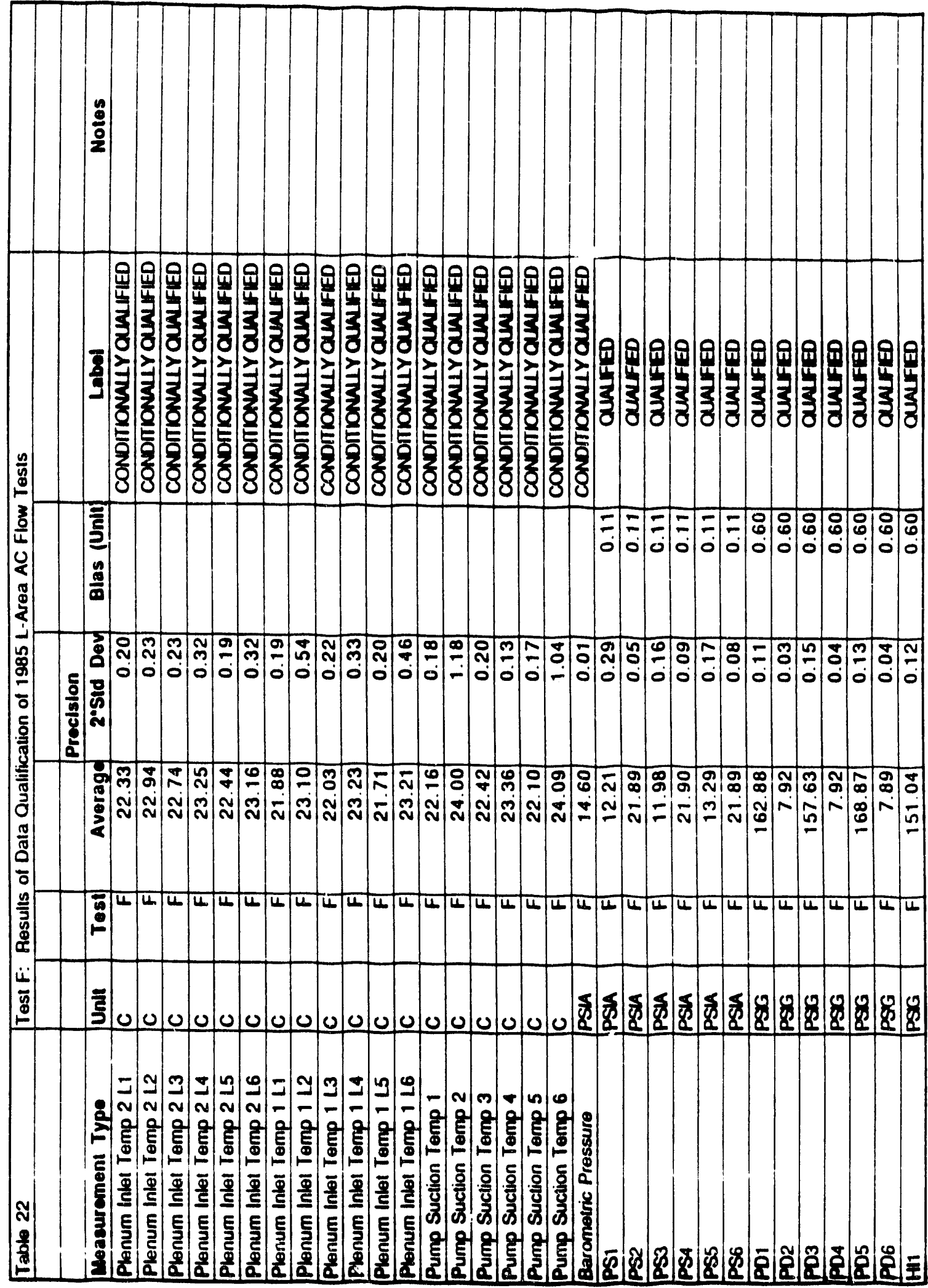




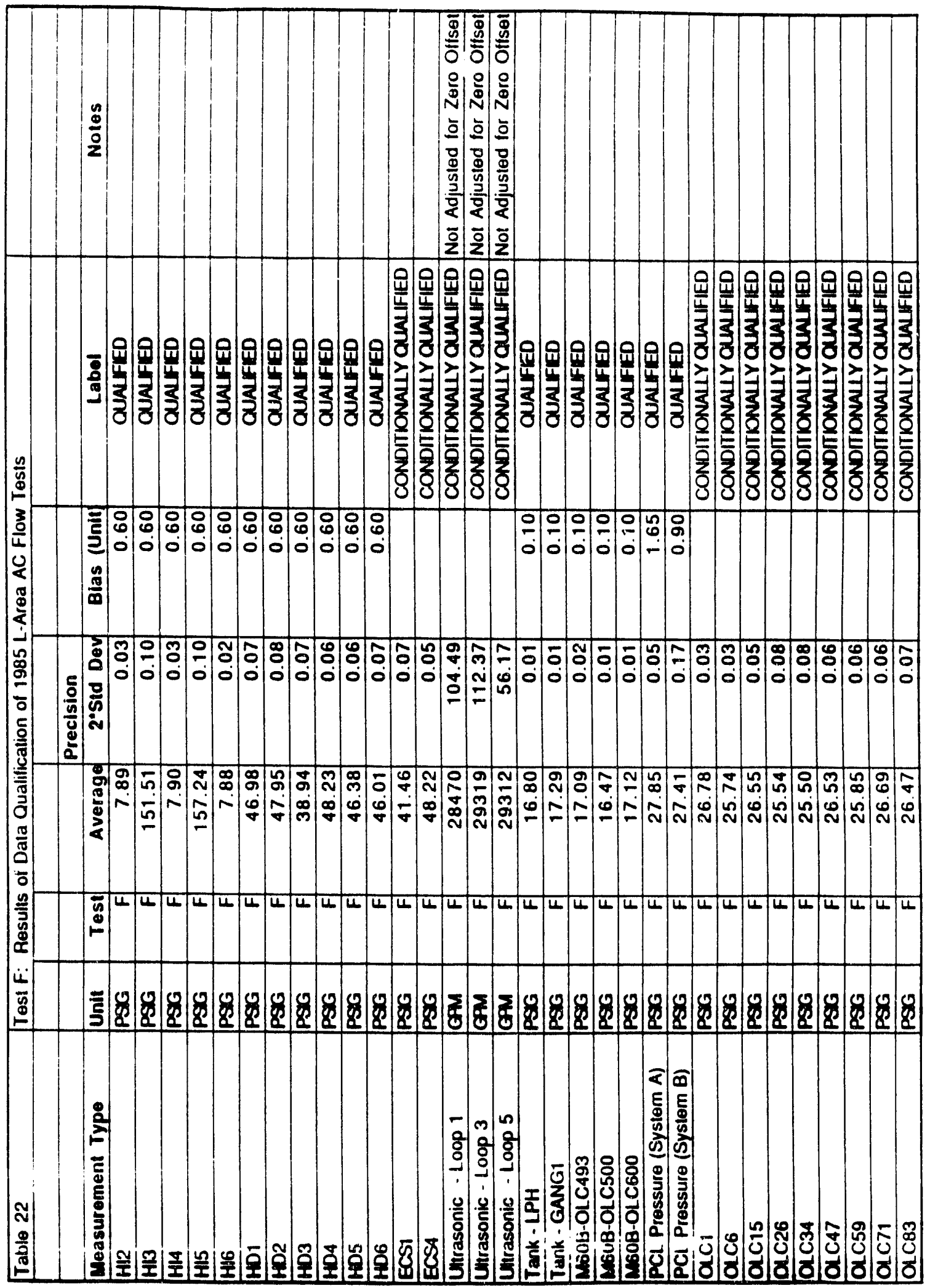




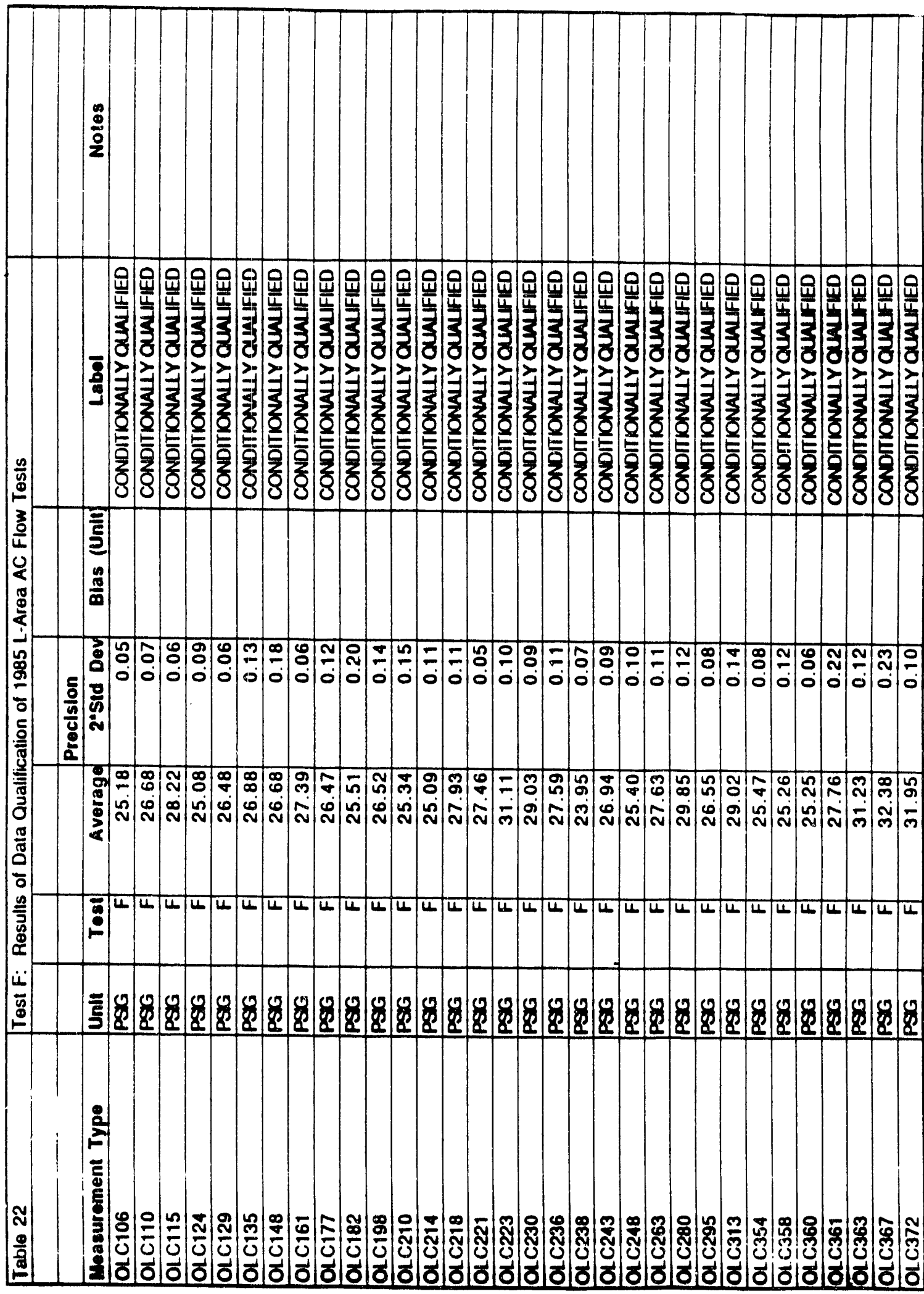


WSRC-TR-92-134

March 10, 1992

Task 91-033-1

DQ Summary for 1985 L-Area AC Flow Tests

Revision 0

Page 93 of 119

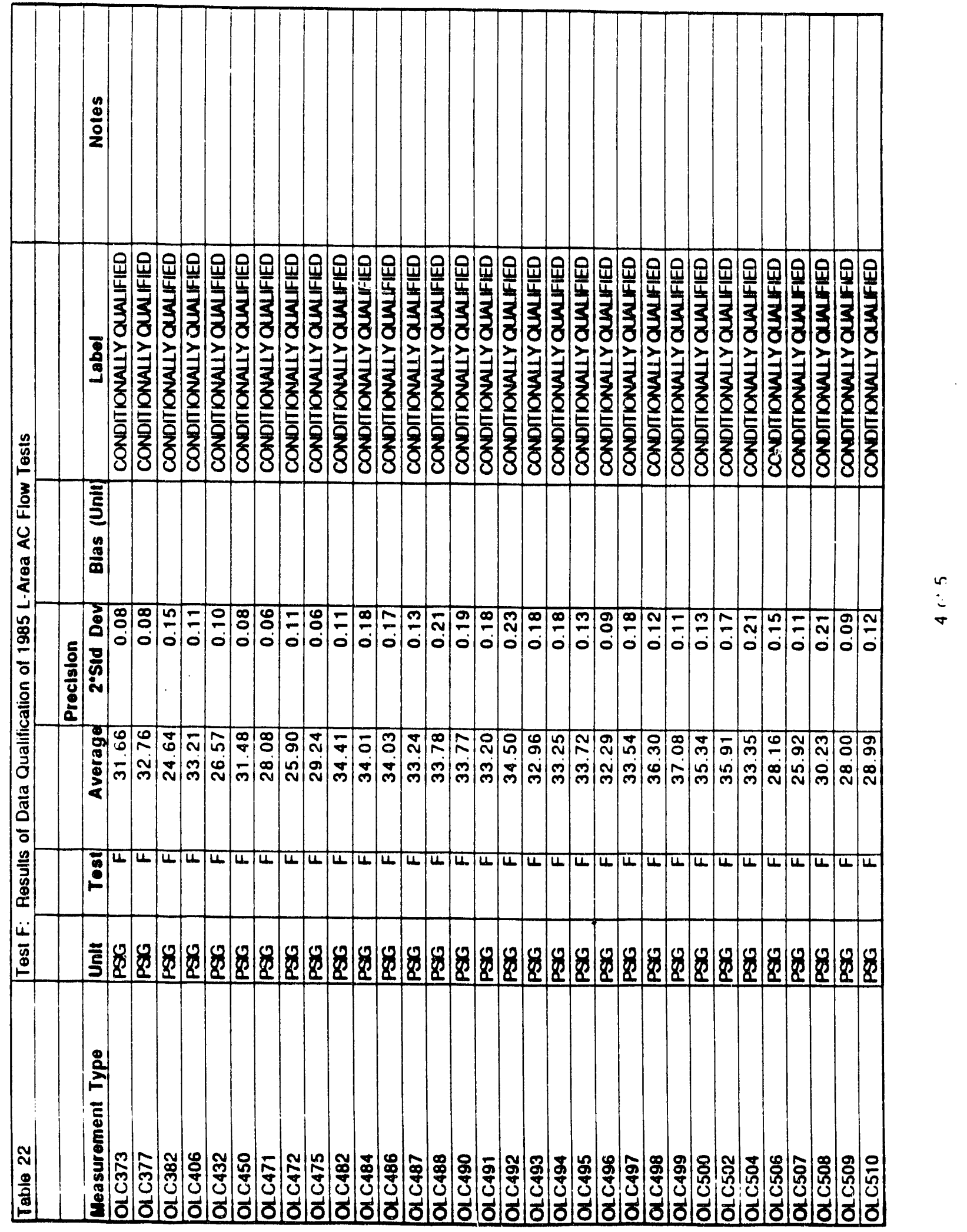




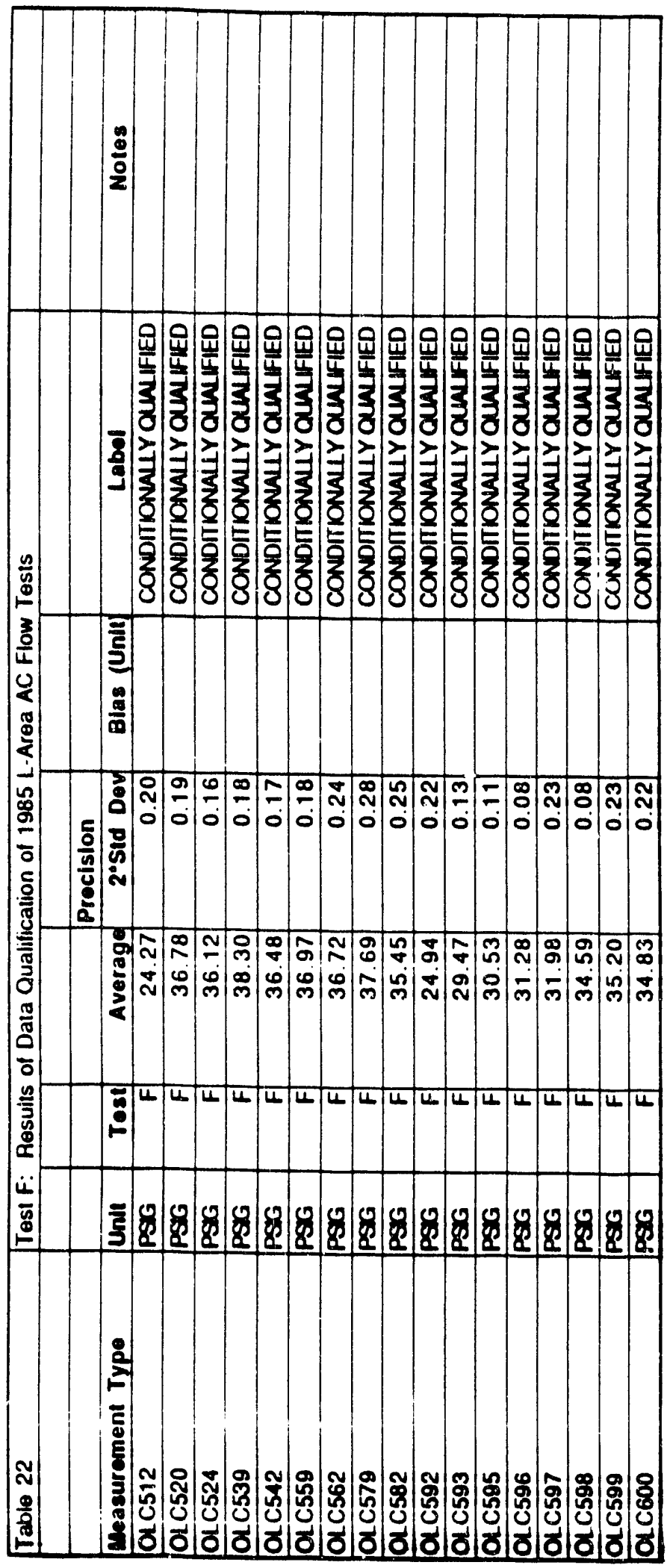




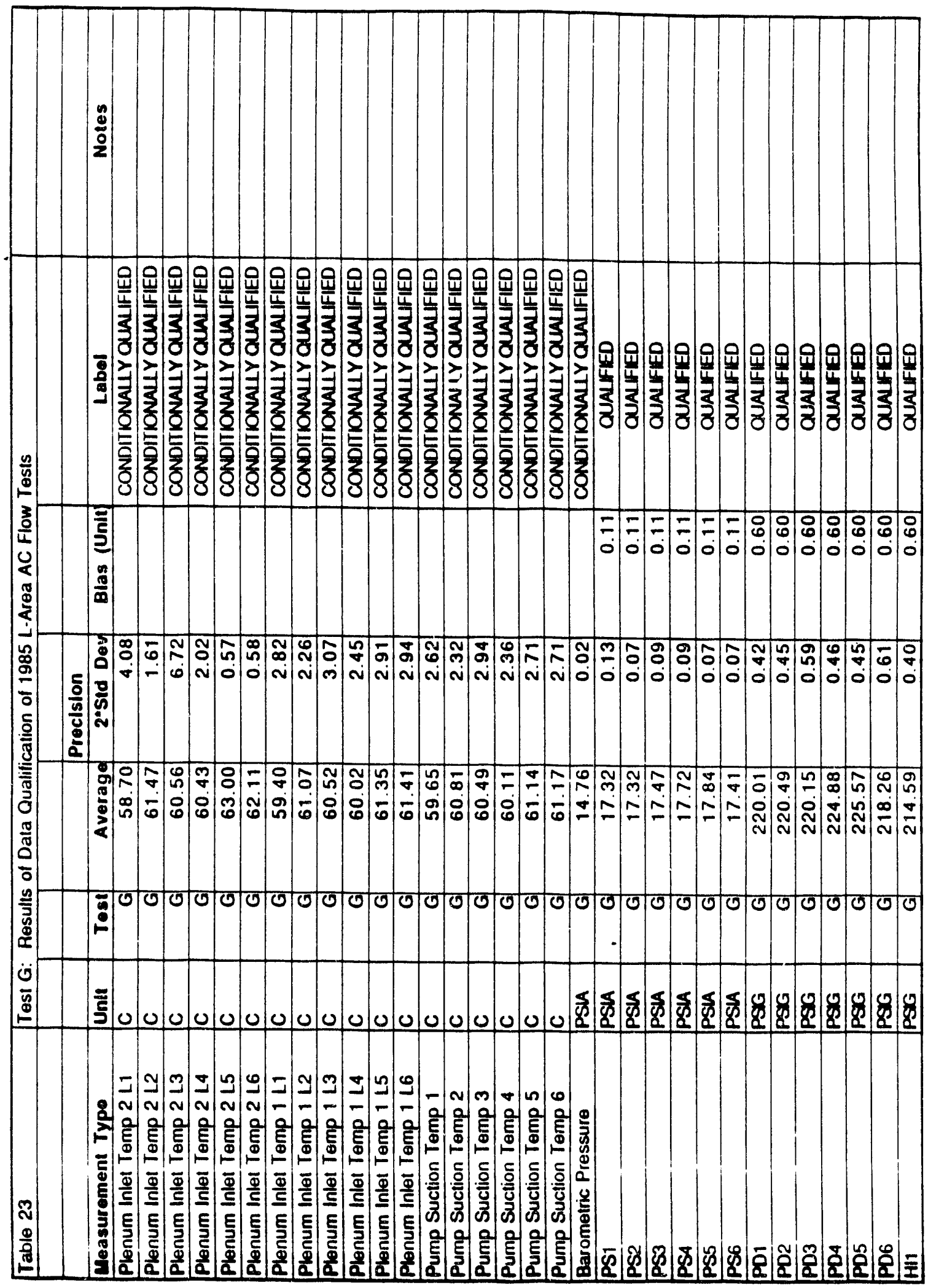


WSRC-TR-92-134

March 10, 1992

Task 91-033-1

DQ Summary for 1985 L-Area AC Flow Tests

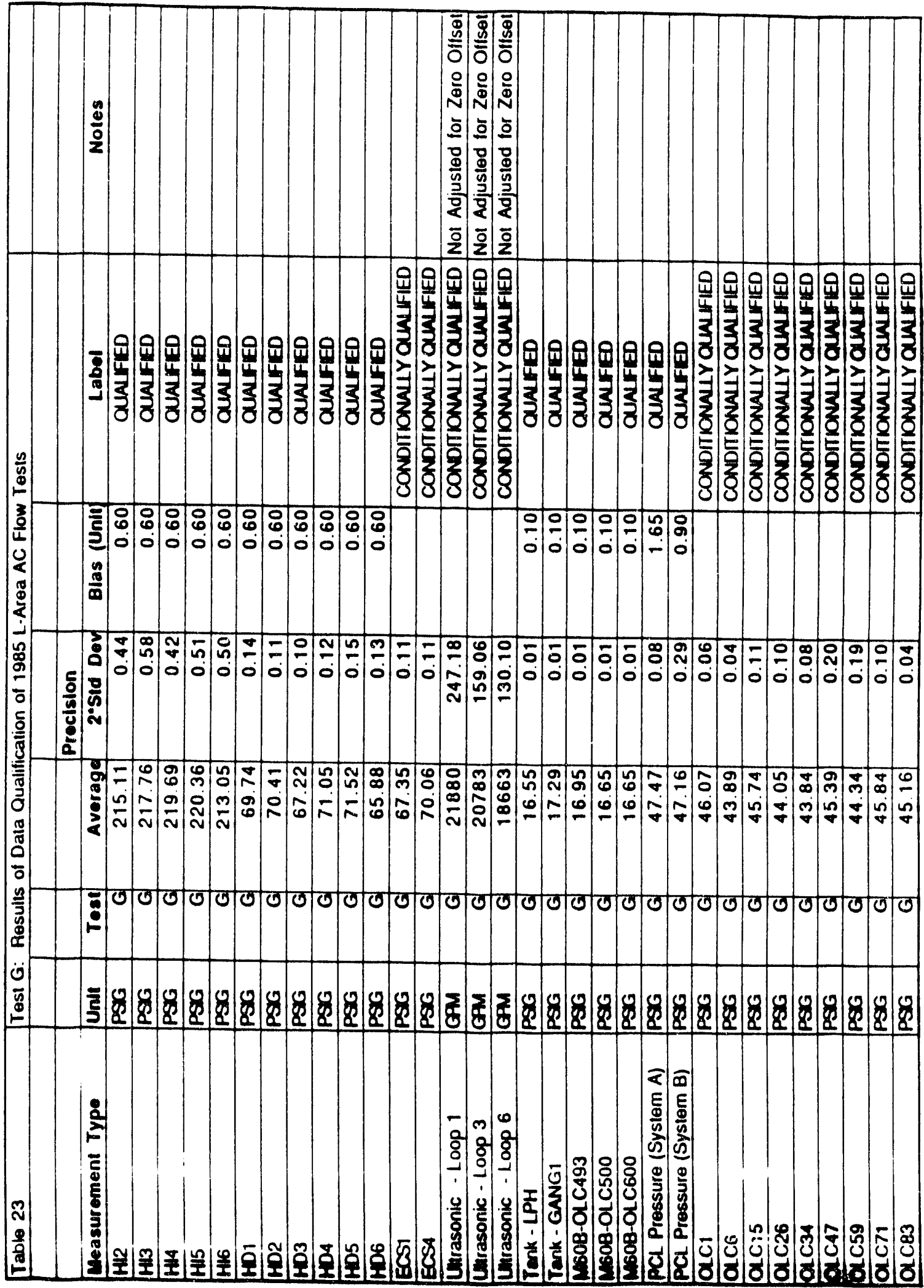




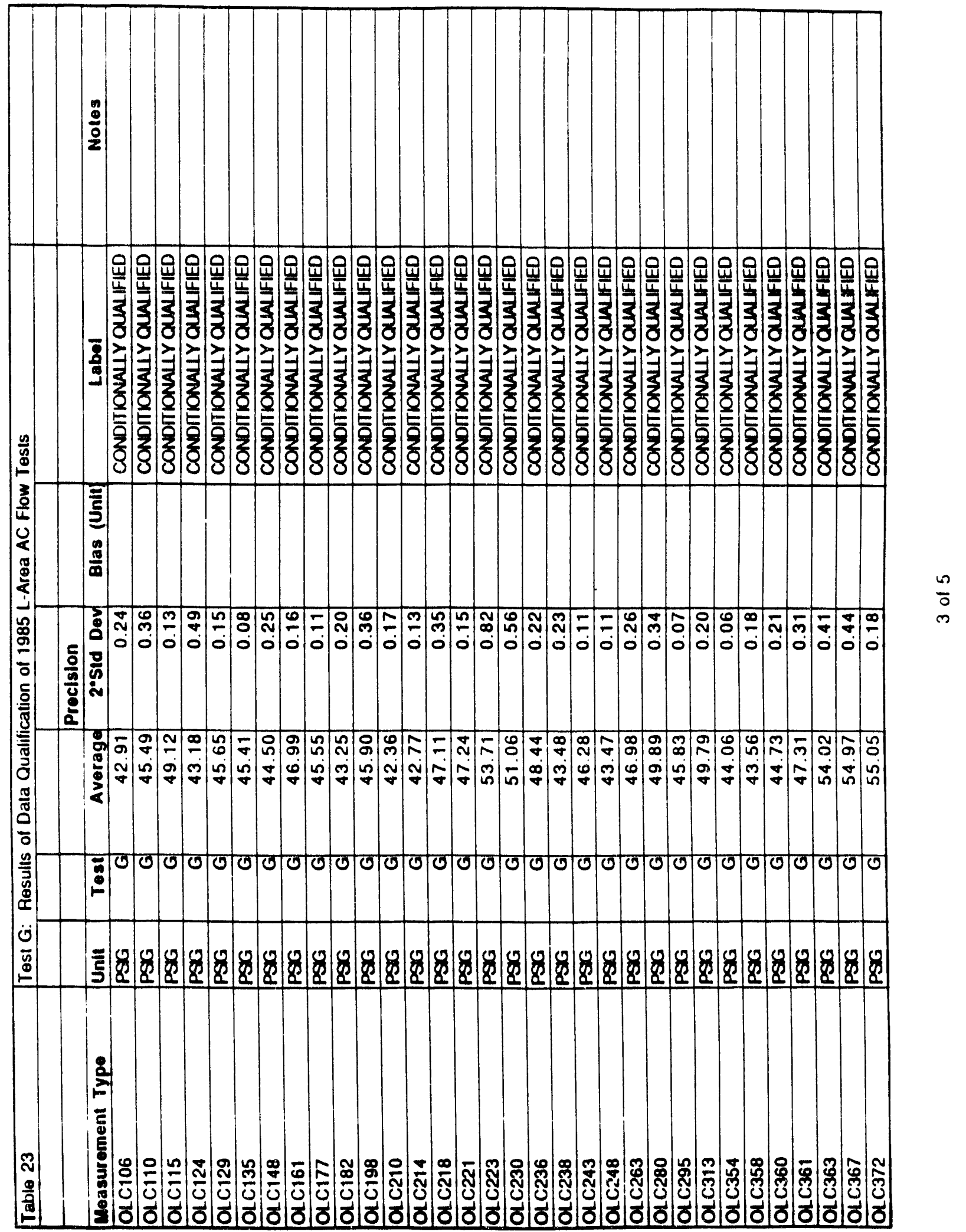


WSRC-TR-92-134

Task 91-033-1

DQ Summary for 1985 L-Area AC Flow Tests

March 10, 1992

Revision 0

Page 98 of 119

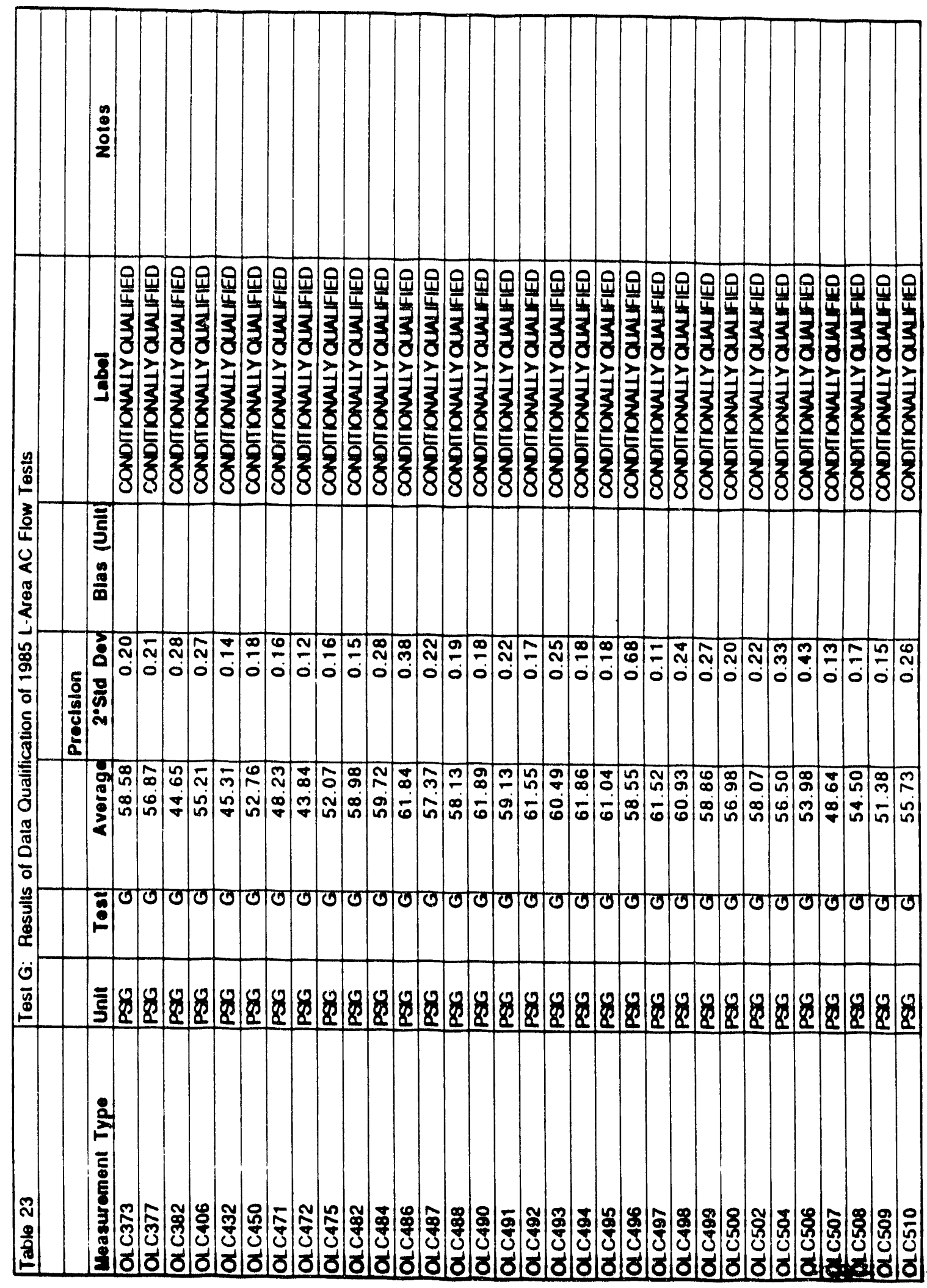




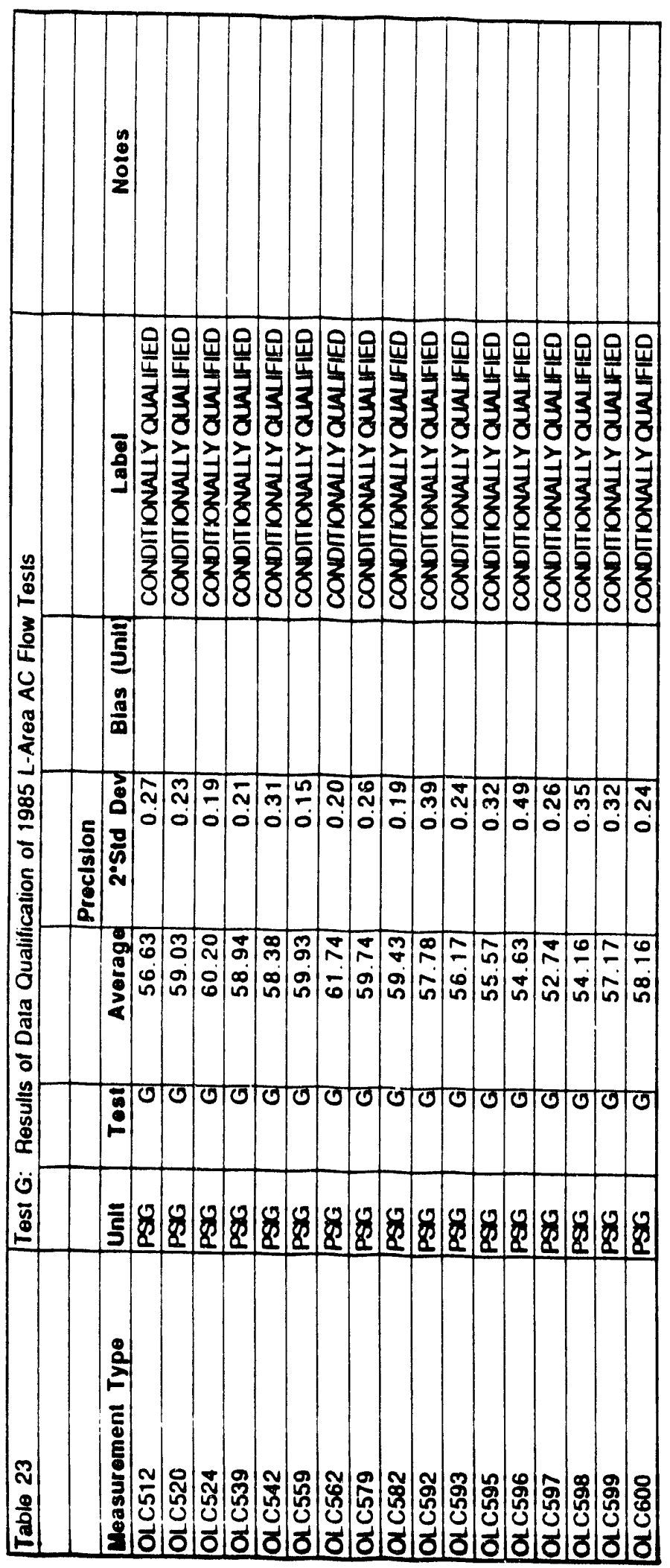


WSRC-TR-92-134

Task 91-033-1

DQ Summary for 1985 L-Area AC Flow Tests

March 10, 1992

Revision 0

Page 100 of 119

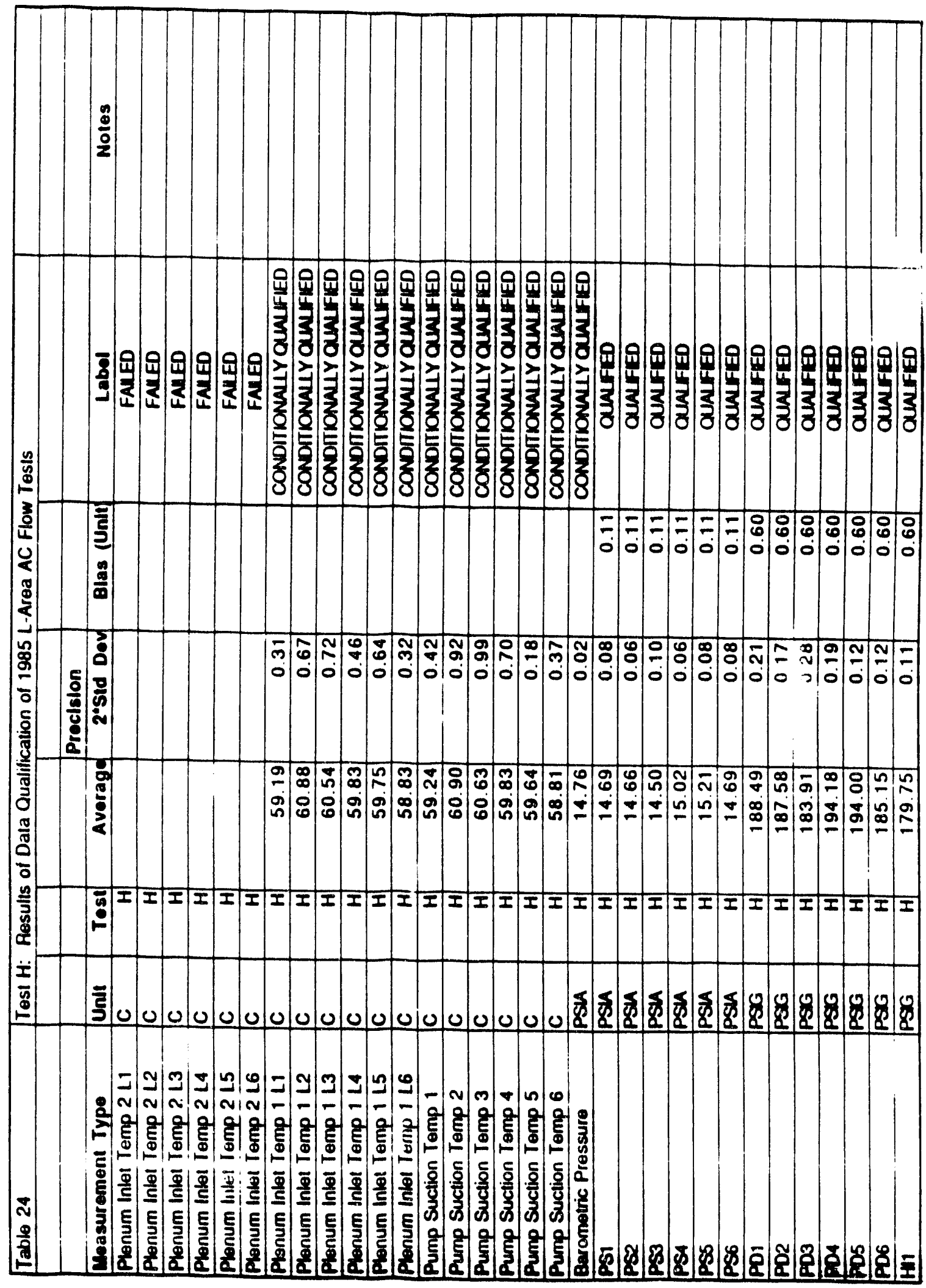




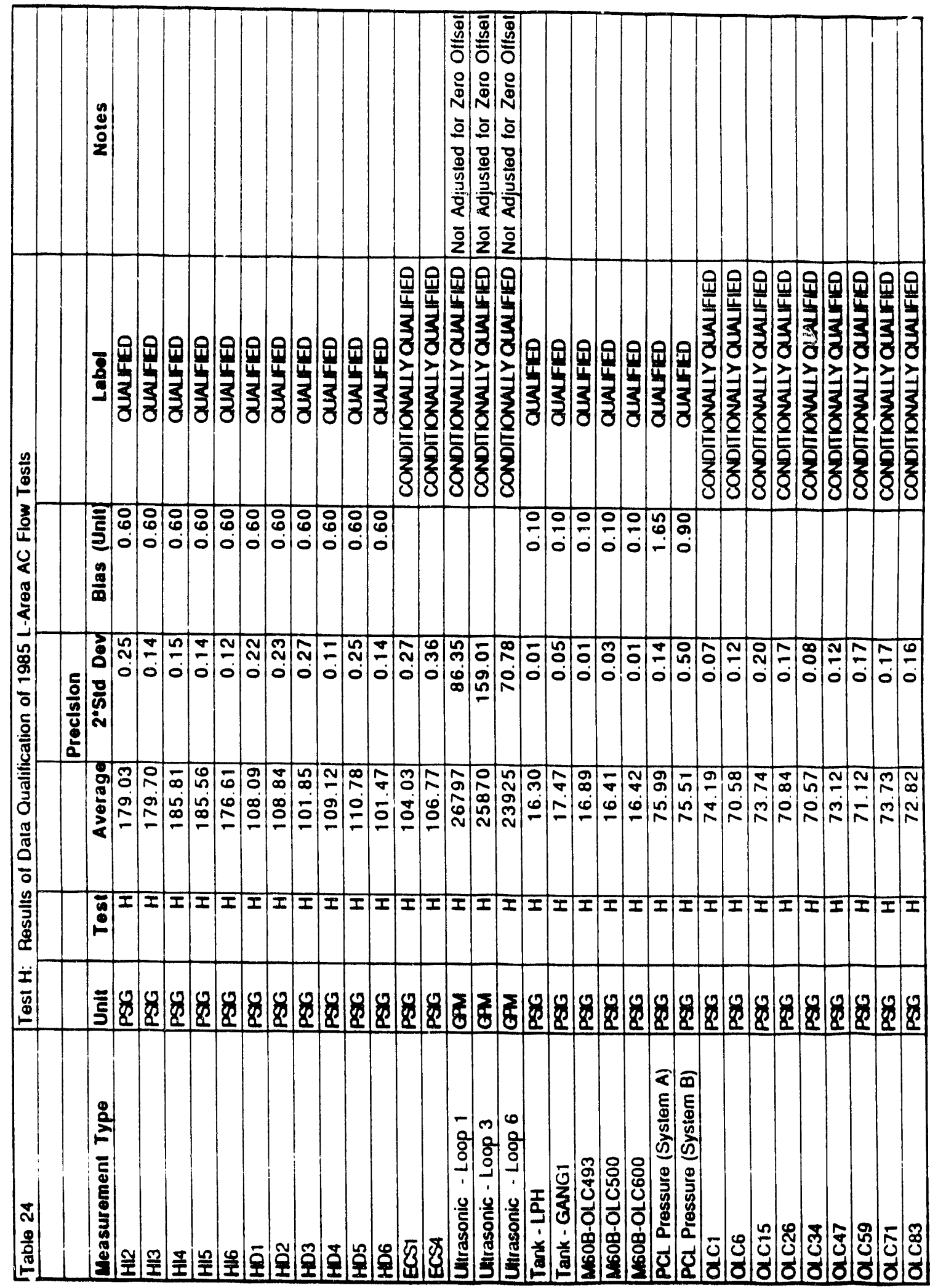


WSRC-TR-92-134

March 10, 1992

Task 91-033-1

Revision 0

DQ Summary for 1985 L-Area AC Flow Tests

Page 102 of 119

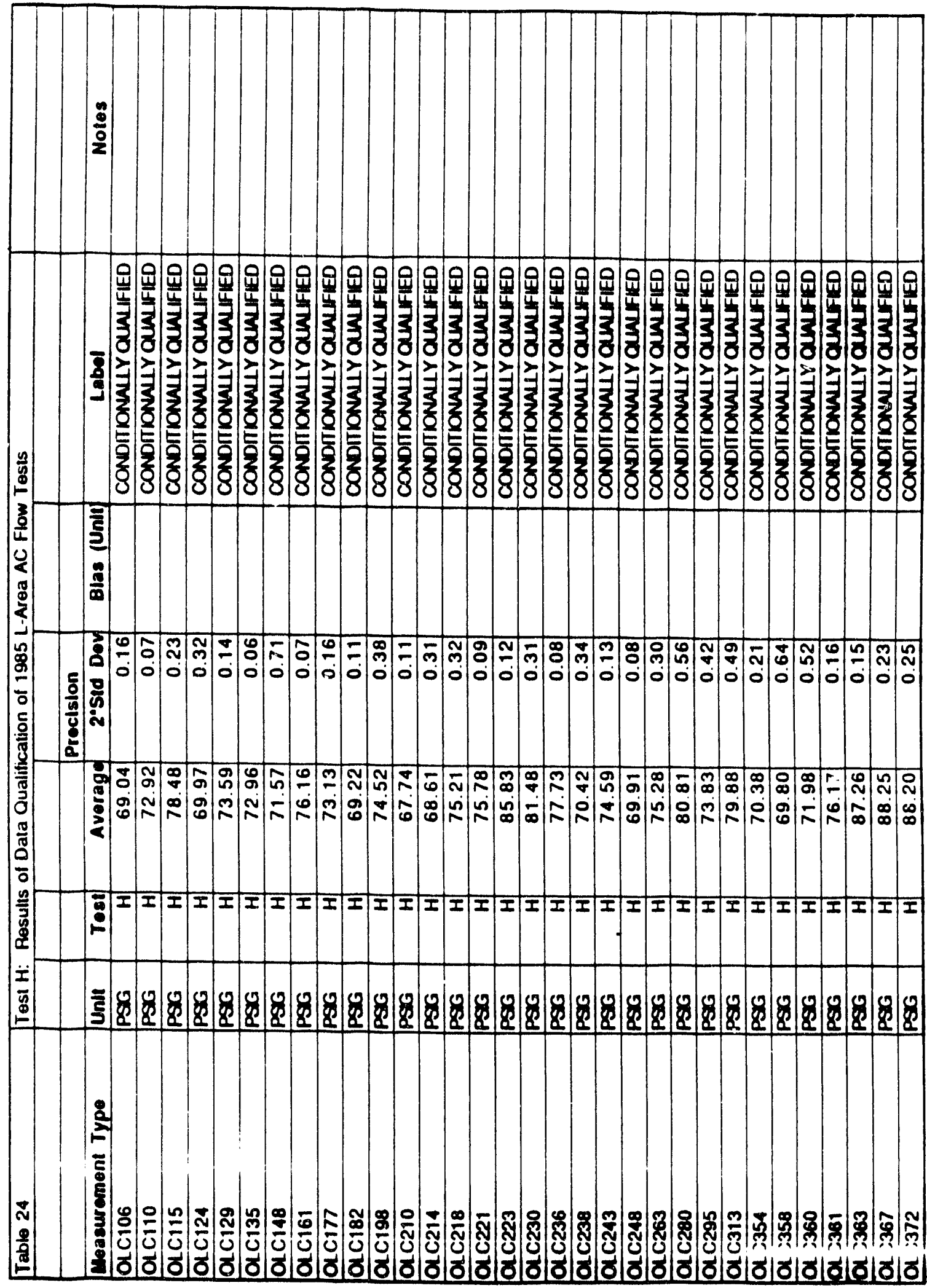


WSRC-TR-92-134

March 10, 1992

Task 91-033-1

DQ Summary for 1985 L-Area AC Flow Tests

Revision 0

Page 103 of 119

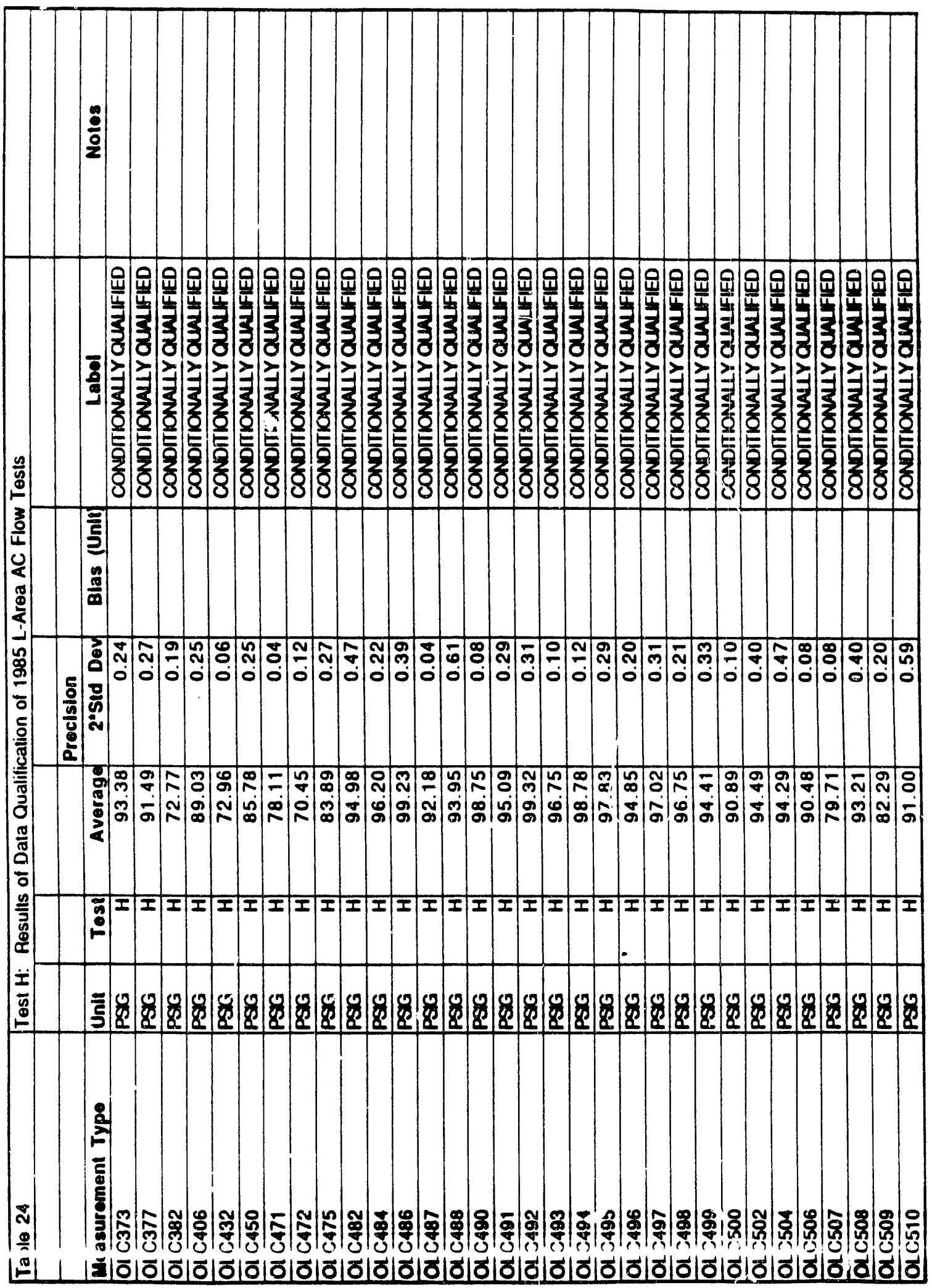




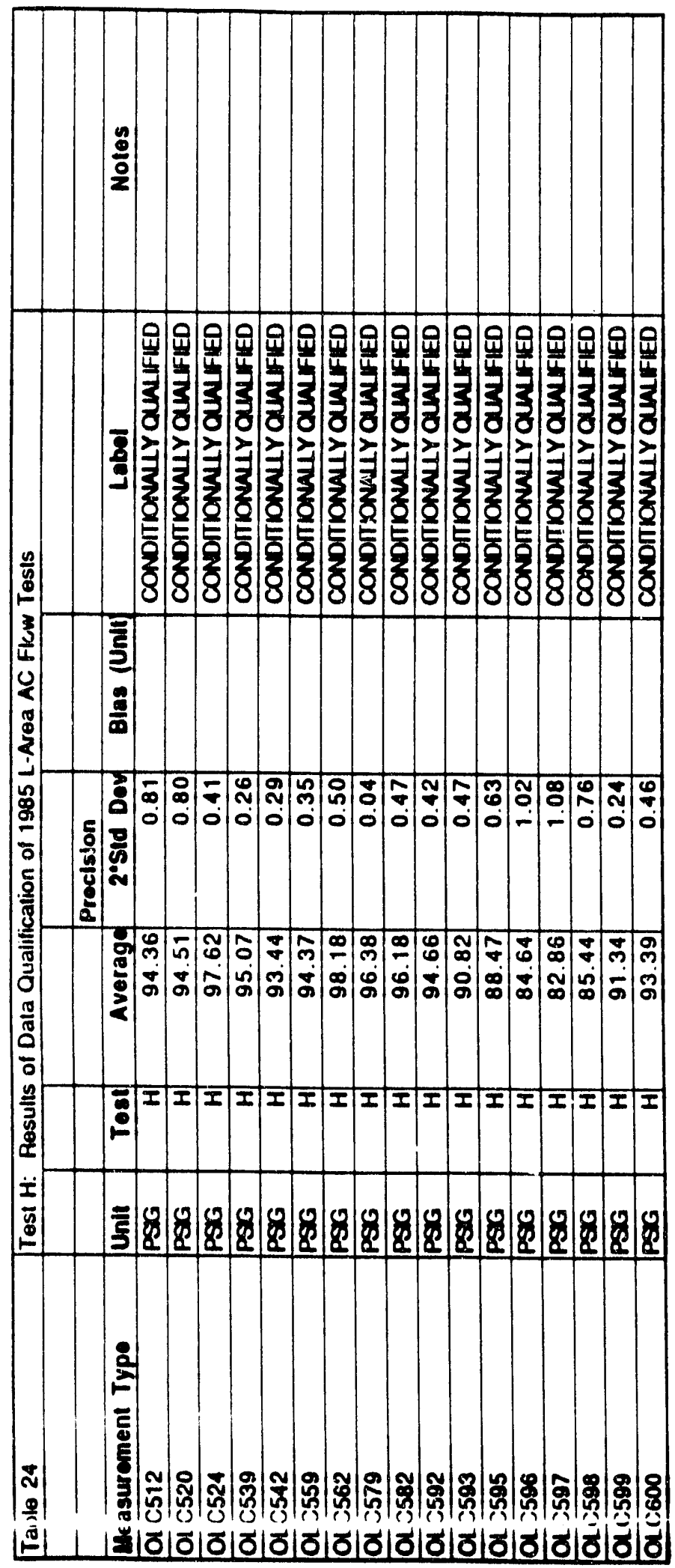




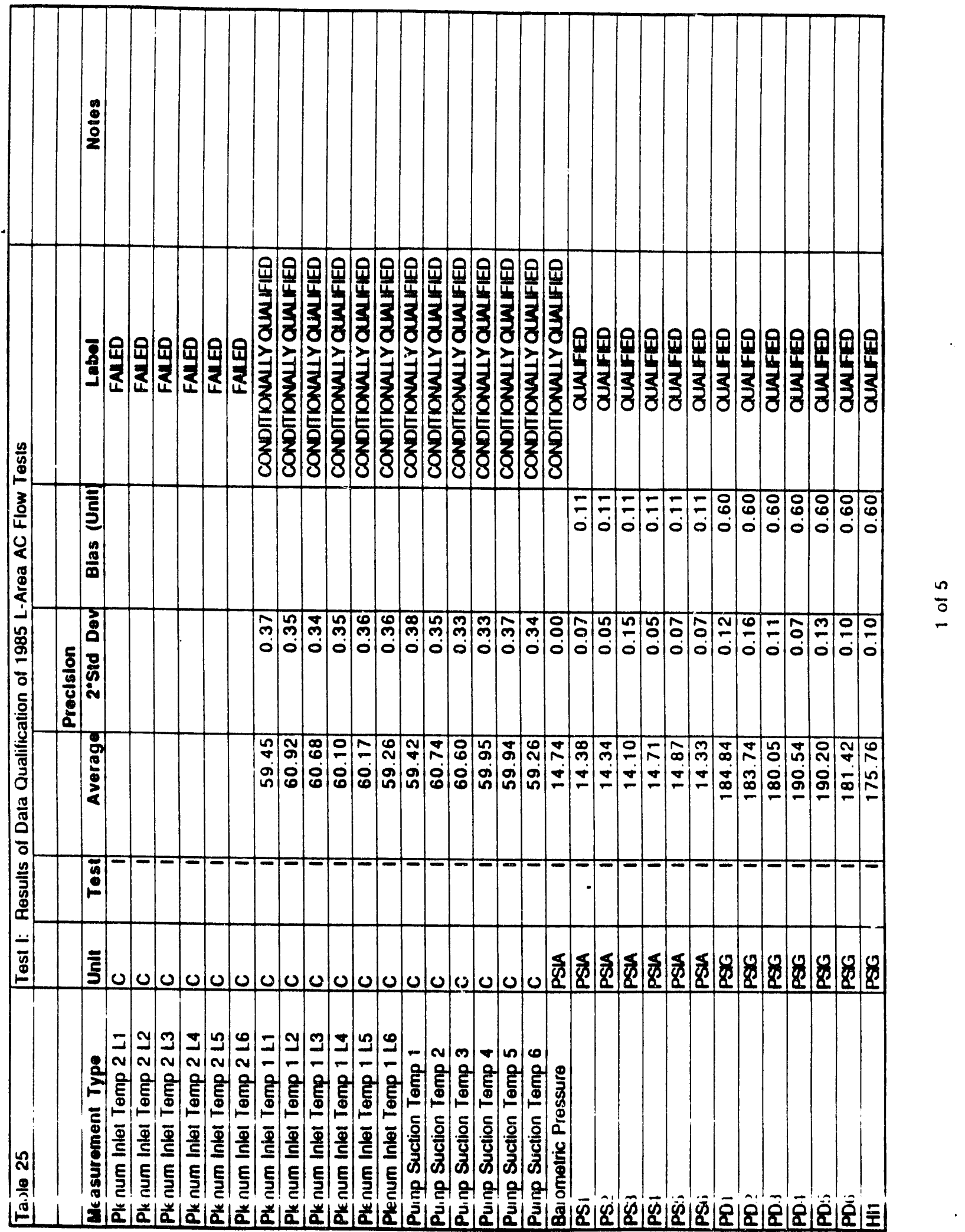




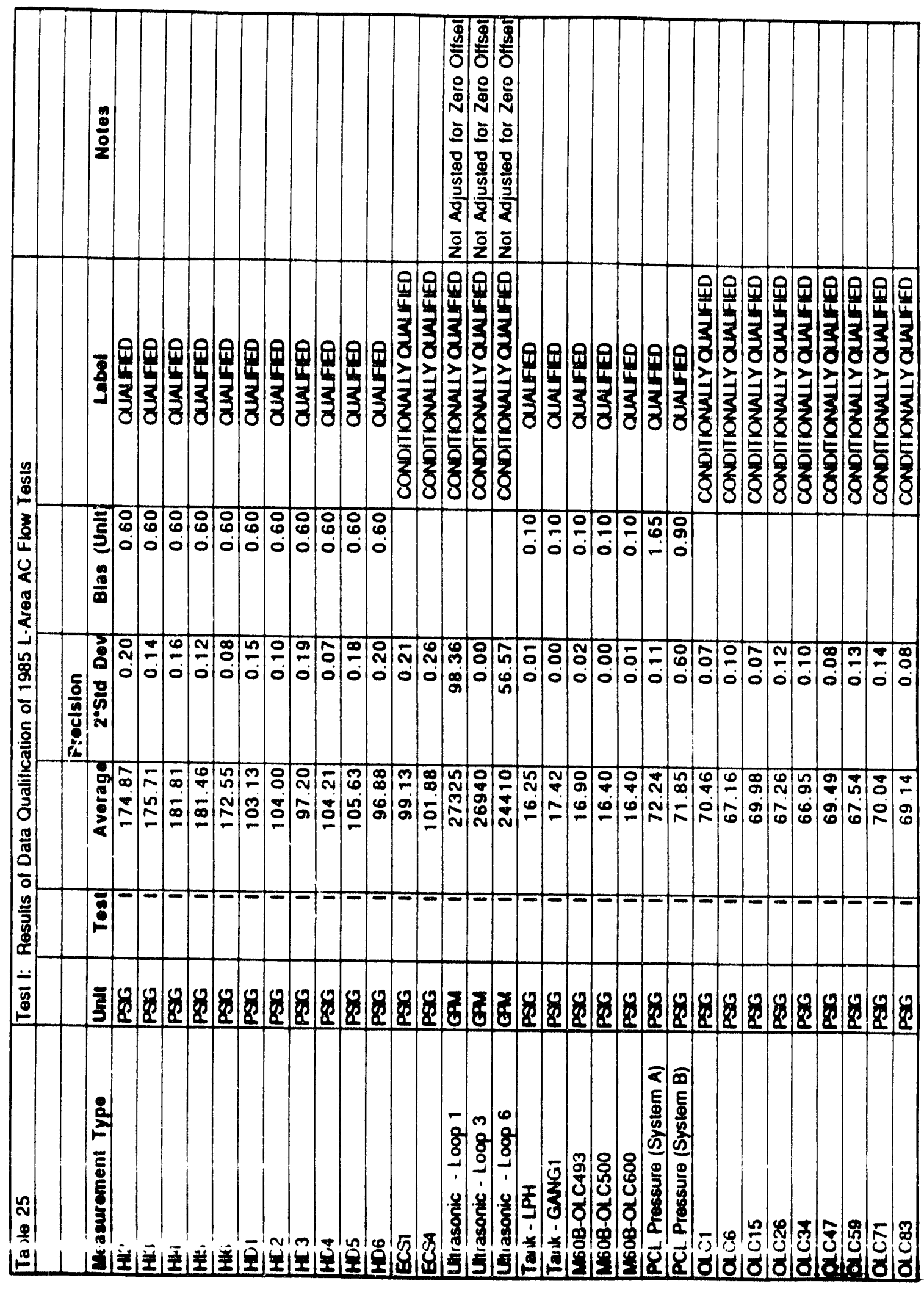


WSRC-TR-92-134

March 10, 1992

Task 91-033-1

DQ Summary for 1985 L-Area AC Flow Tests

Revision 0

Page 107 of 119

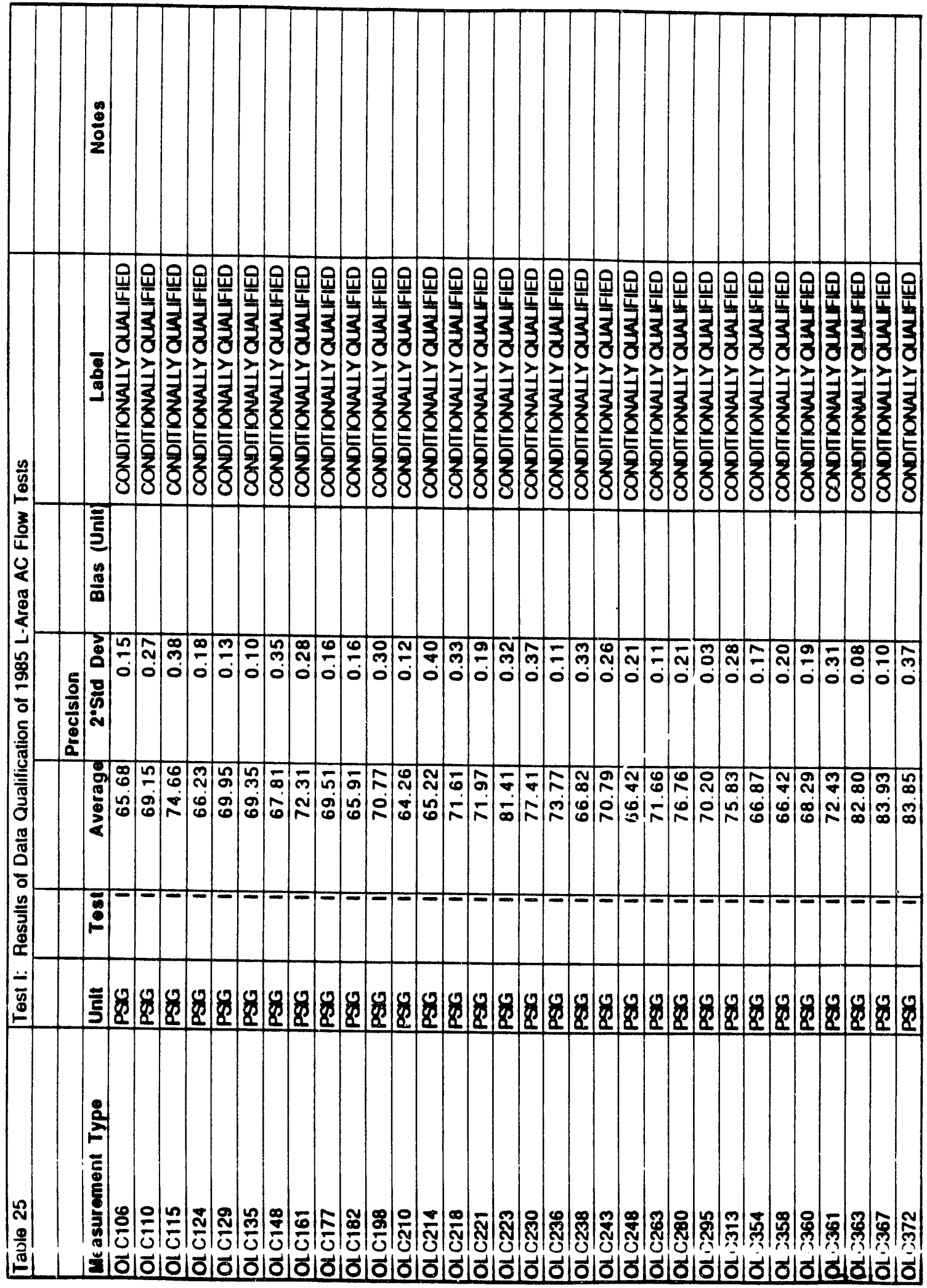


WSRC-TR-92-134

March 10, 1992

Task 91-033-1

Revision 0

DQ Summary for 1985 L-Area AC Flow Tests

Page 108 of 119

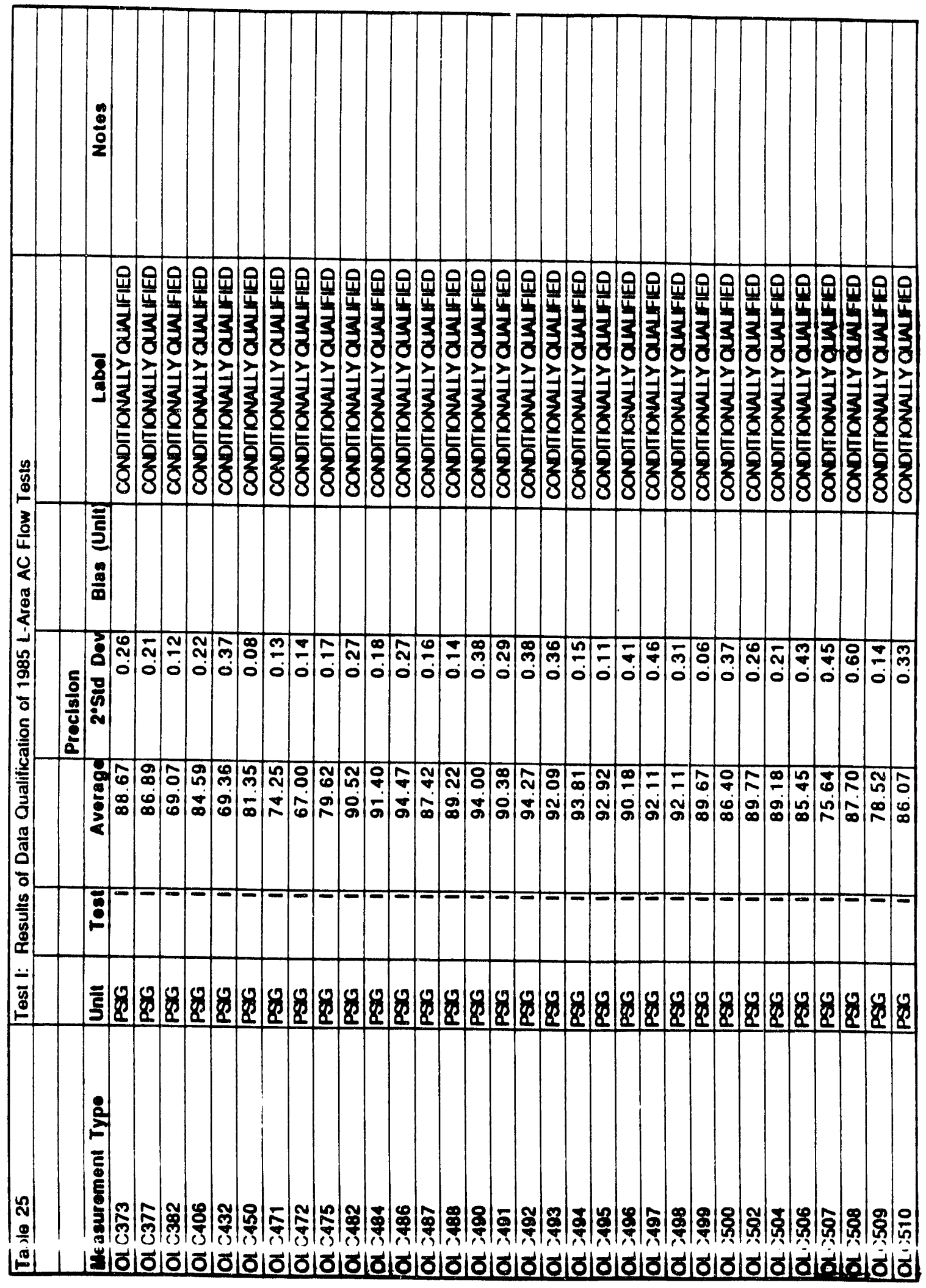




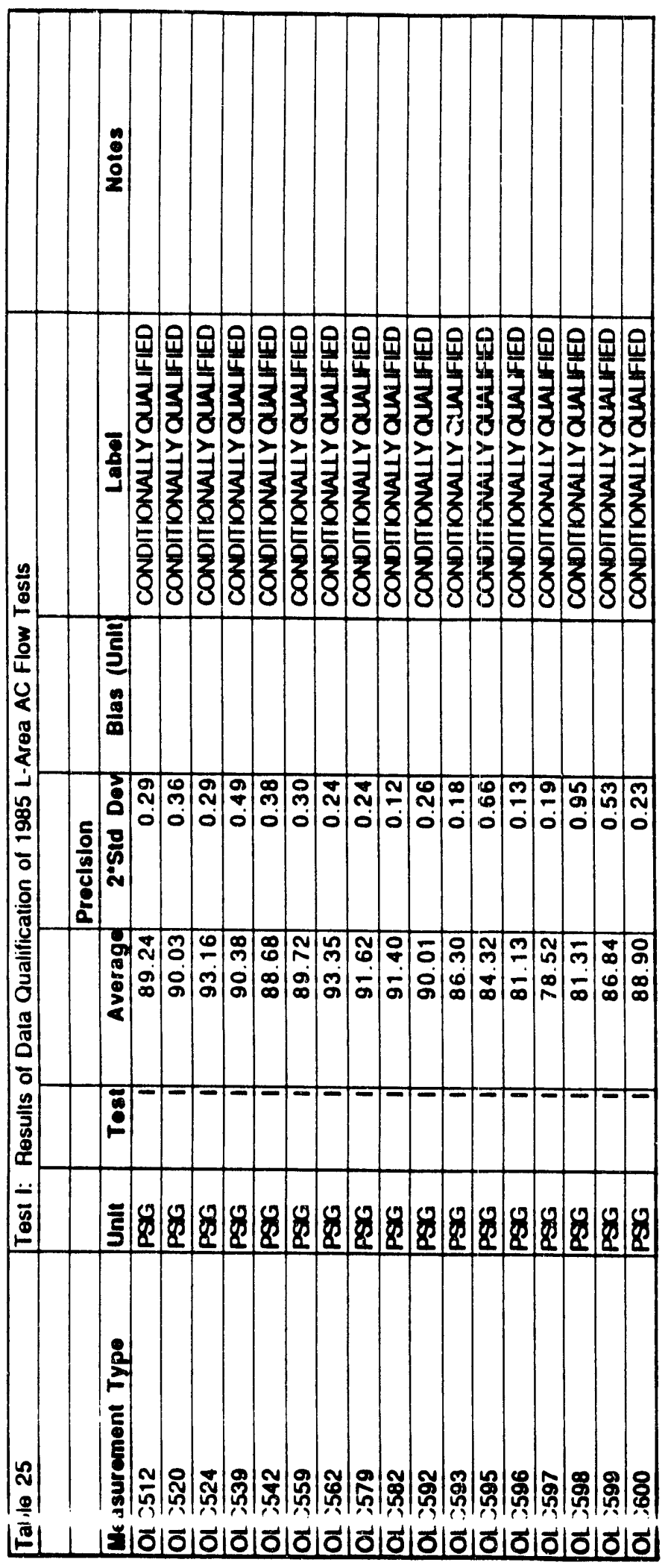




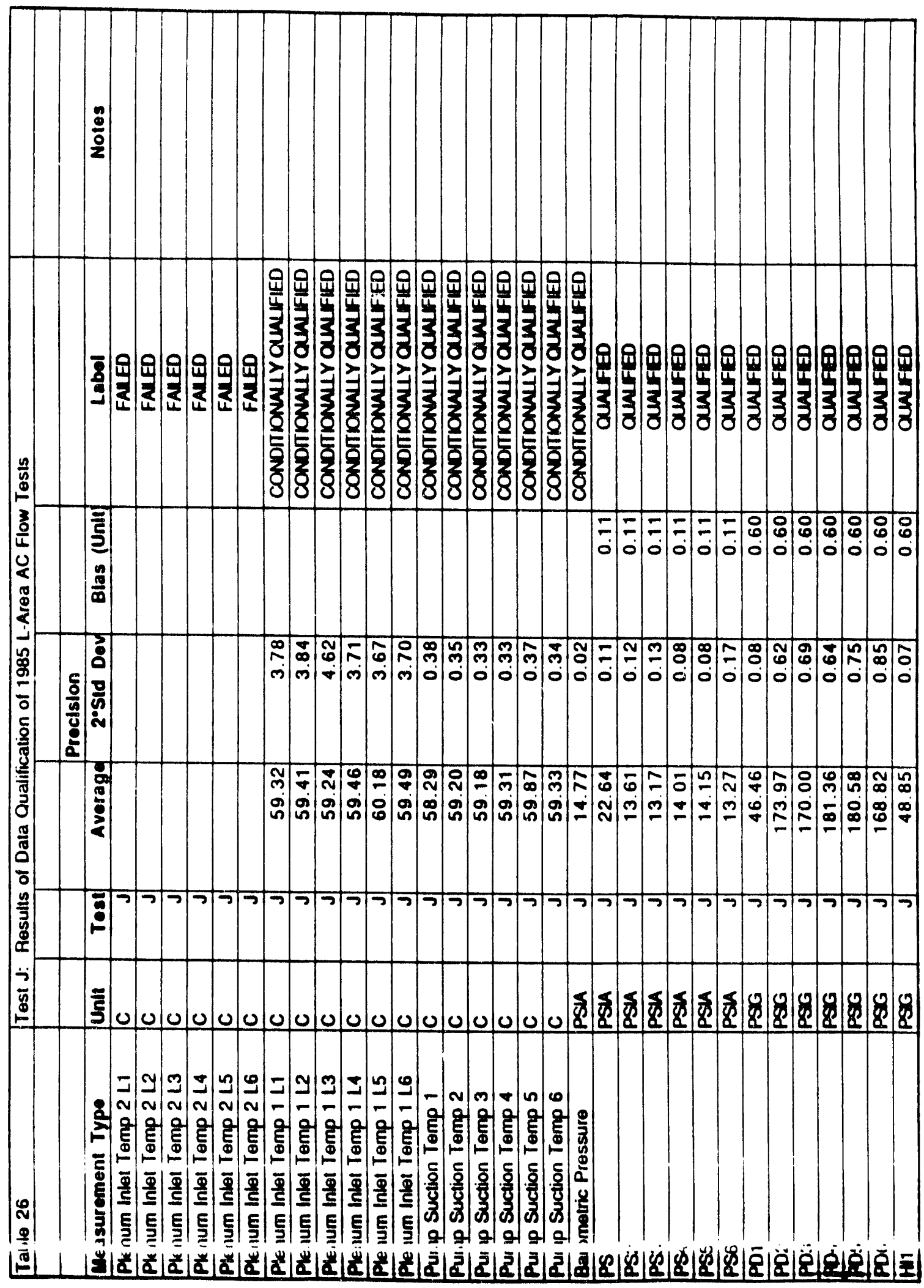


WSRC-TR-92-134

Task 91-033-1

DQ Summary for 1985 L-Area AC Flow Tests
March 10, 1992

Revision 0

Page 111 of 119

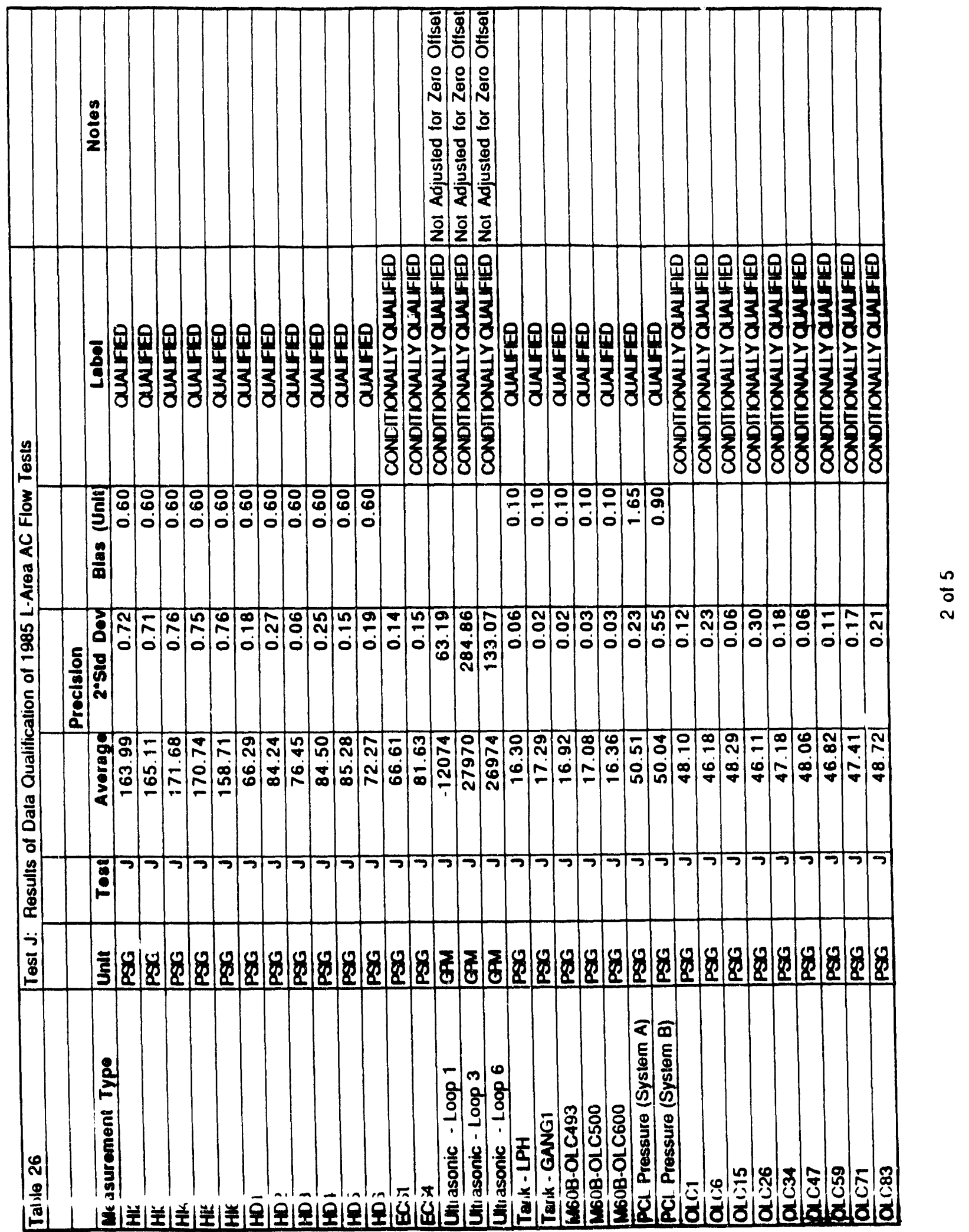




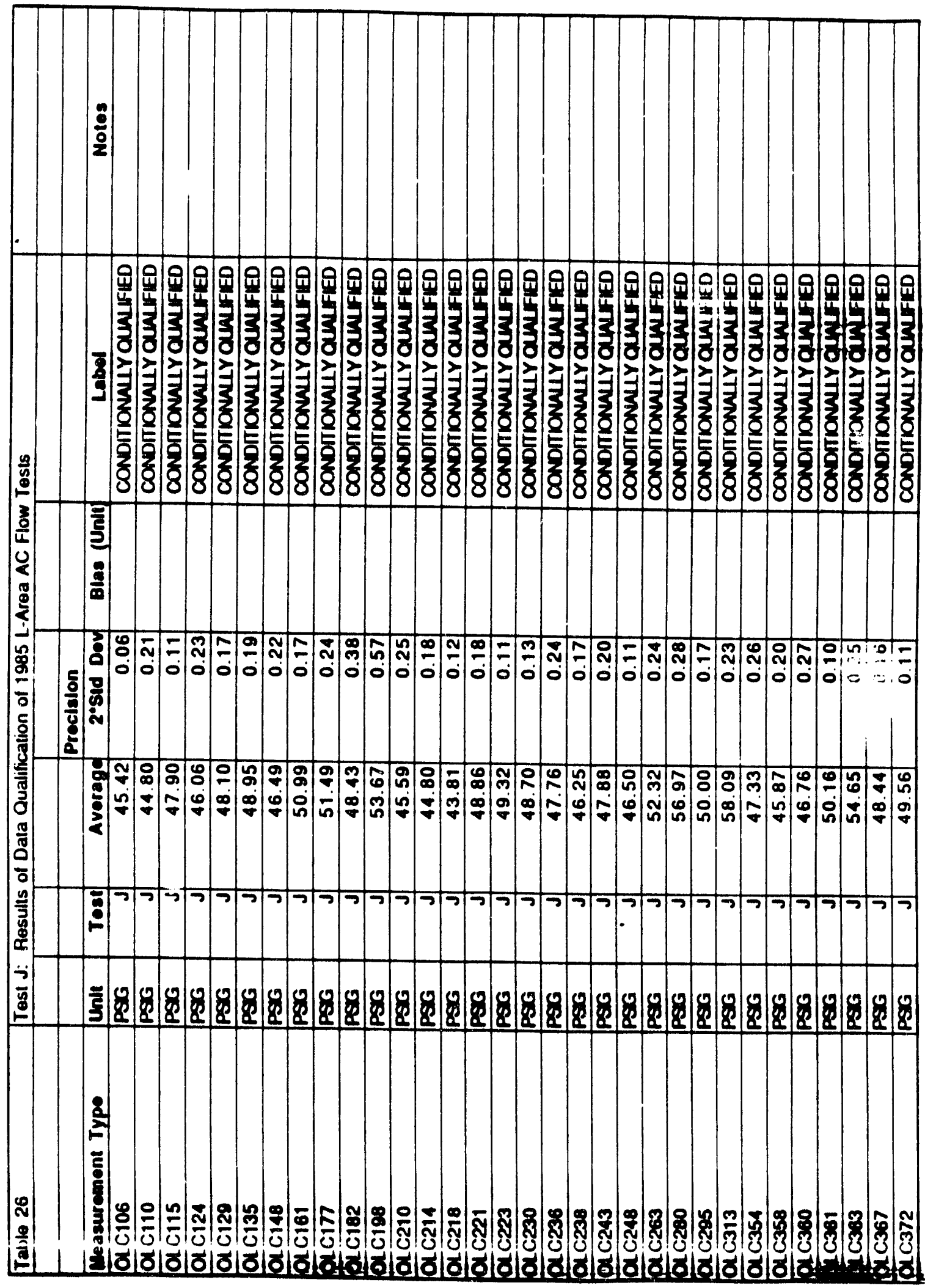




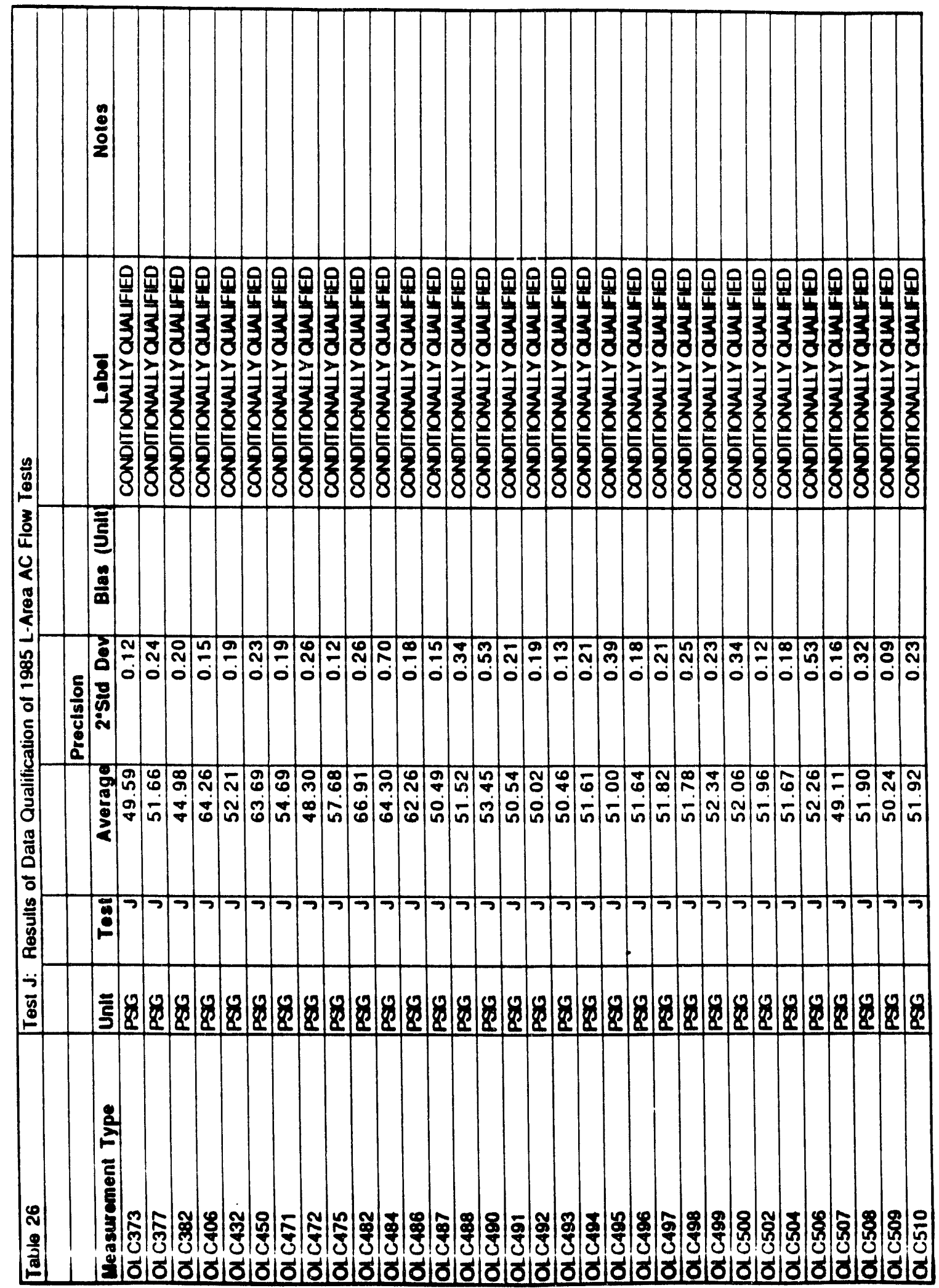


WSRC-TR-92-134

Task 91-033-1

DQ Summary for 1985 L-Area AC Flow Tests

March 10, 1992

Revision 0

Page 114 of 119

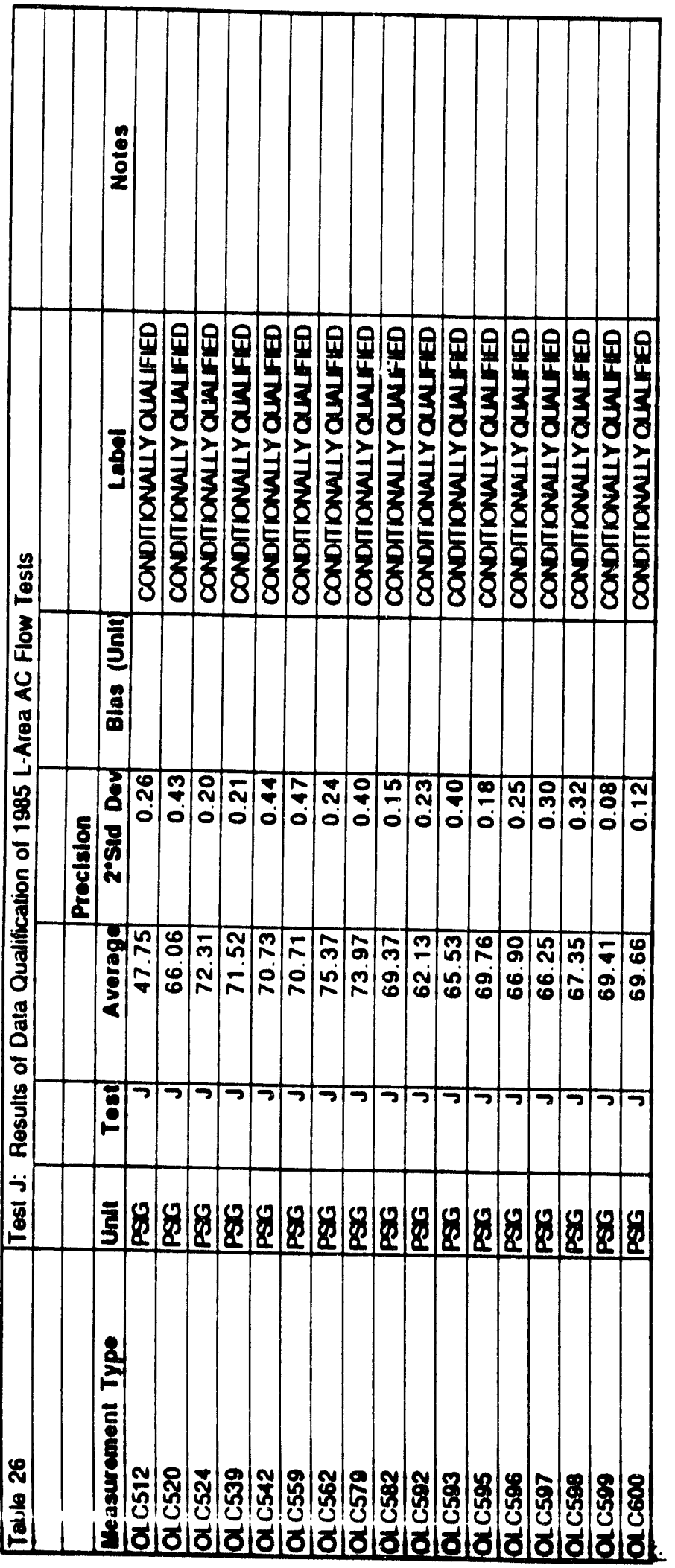


Task 91-033-1

Revision 0

DQ Summary for 1985 L-Area AC Flow Tests

Page 115 of 119

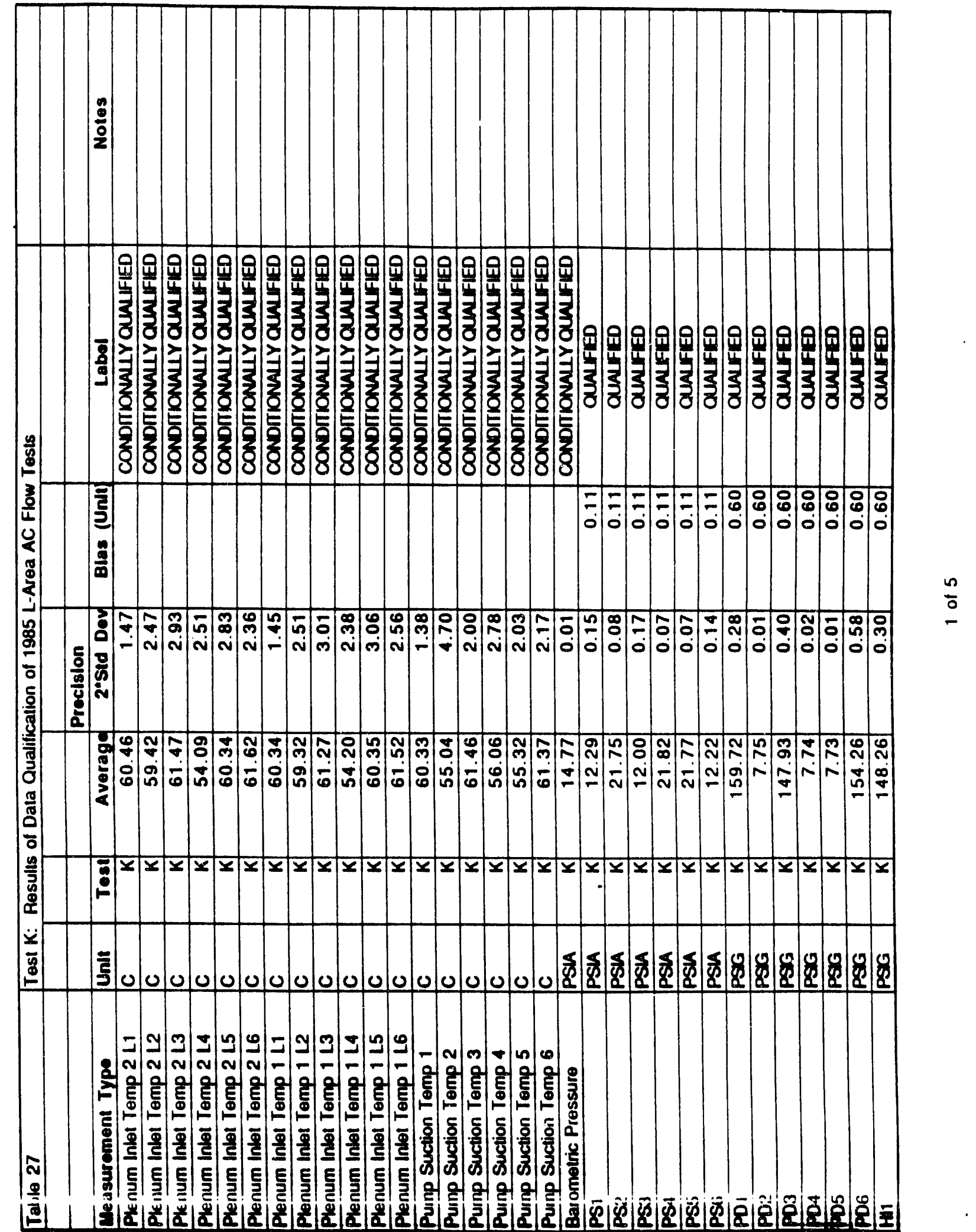




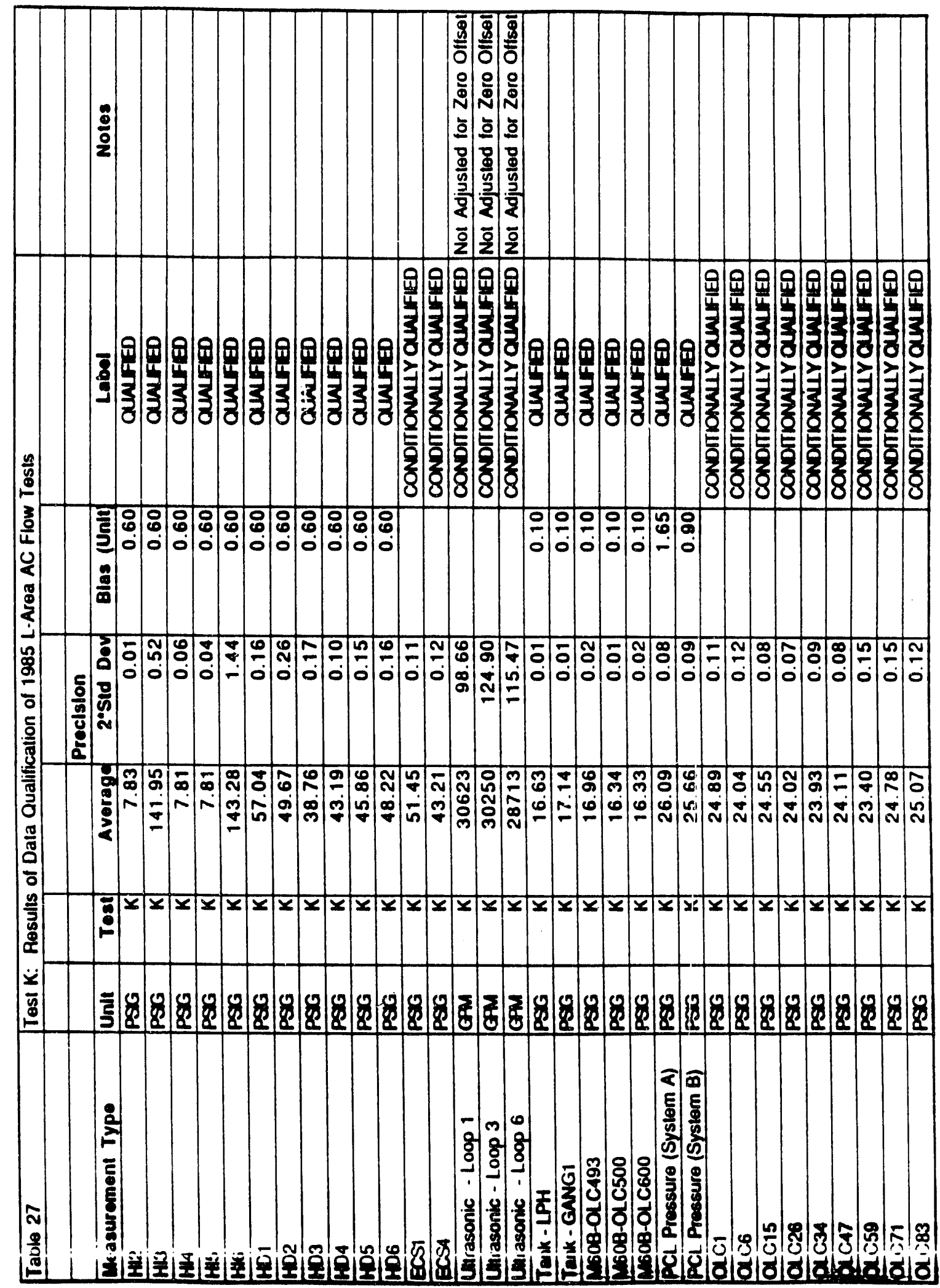




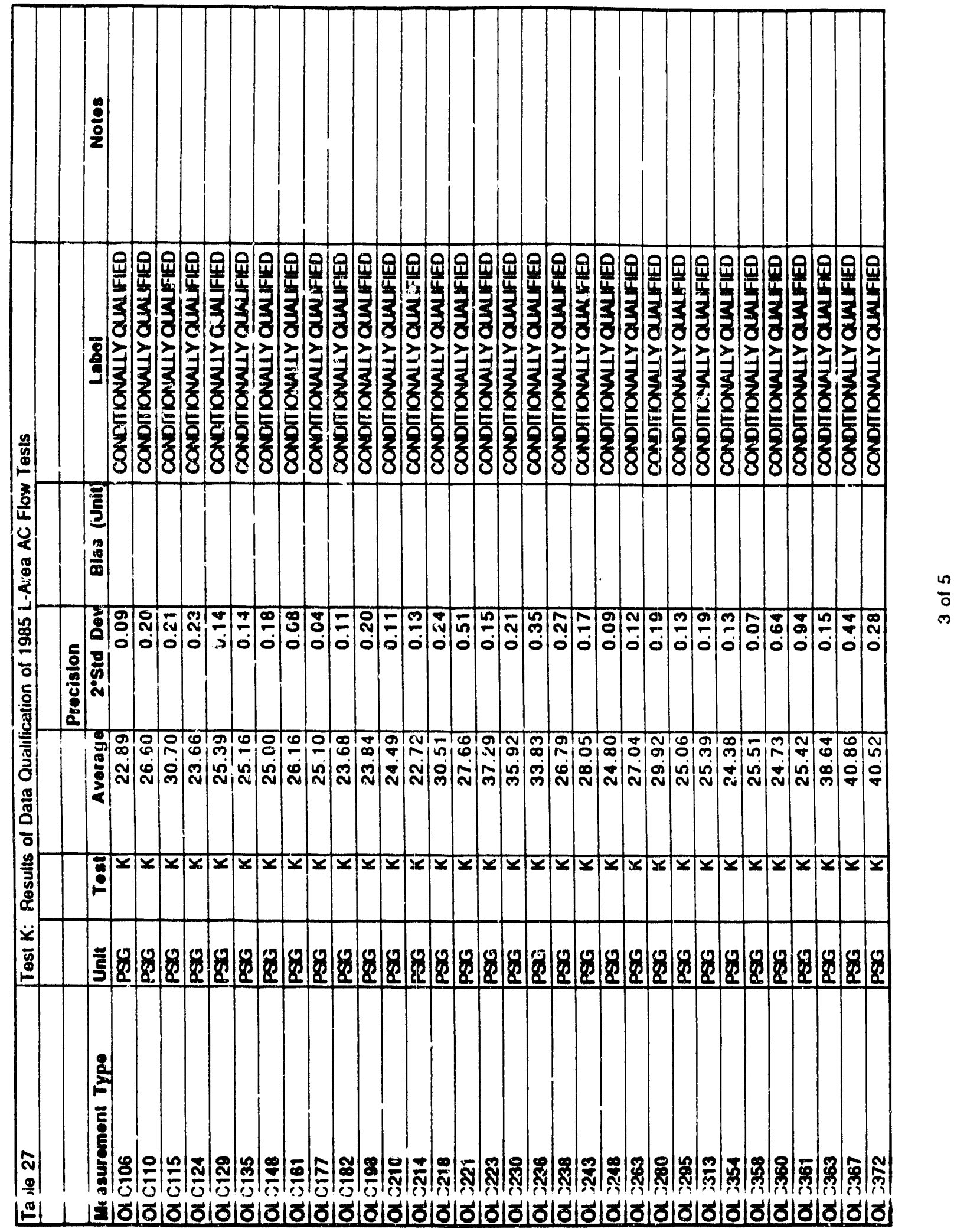




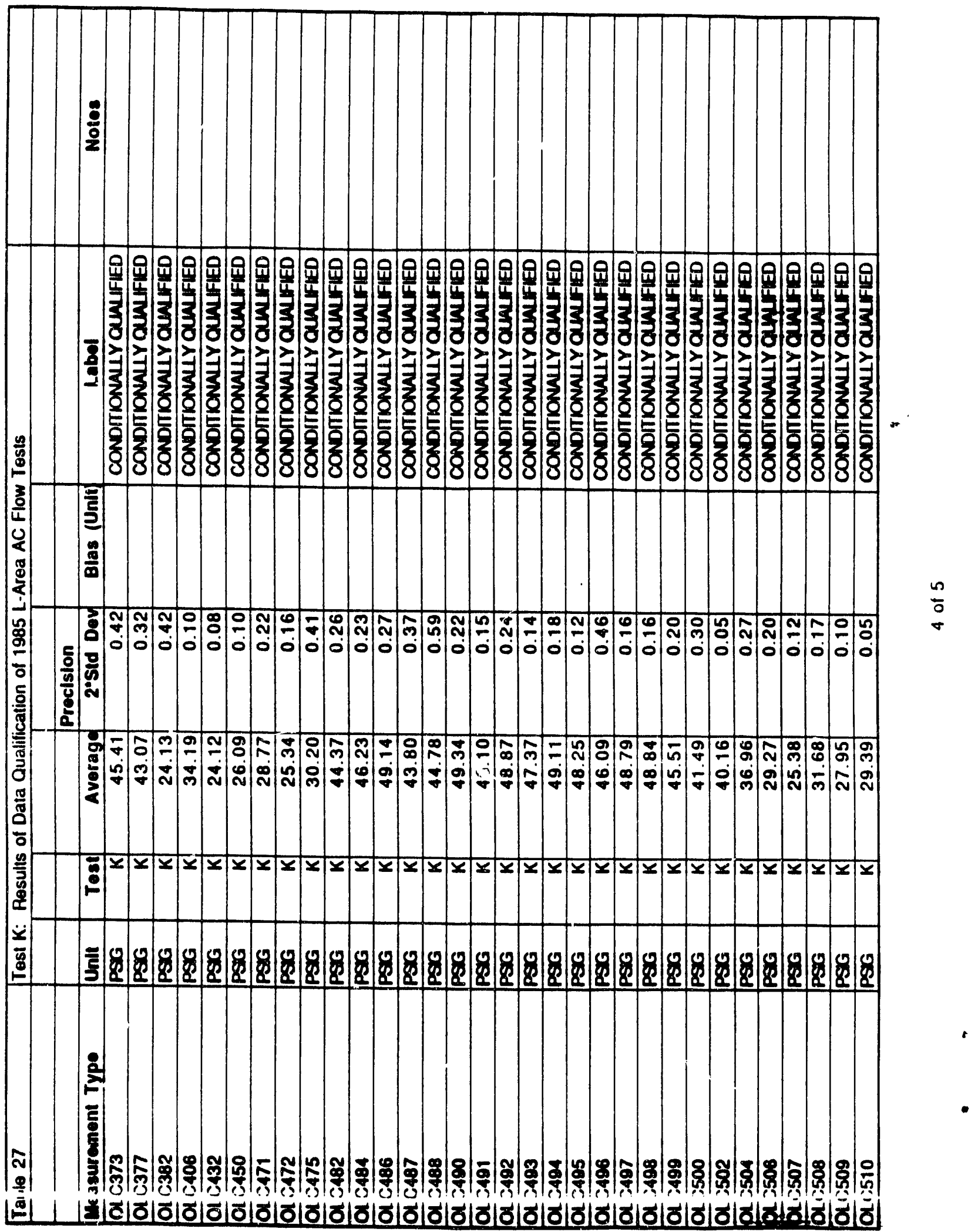




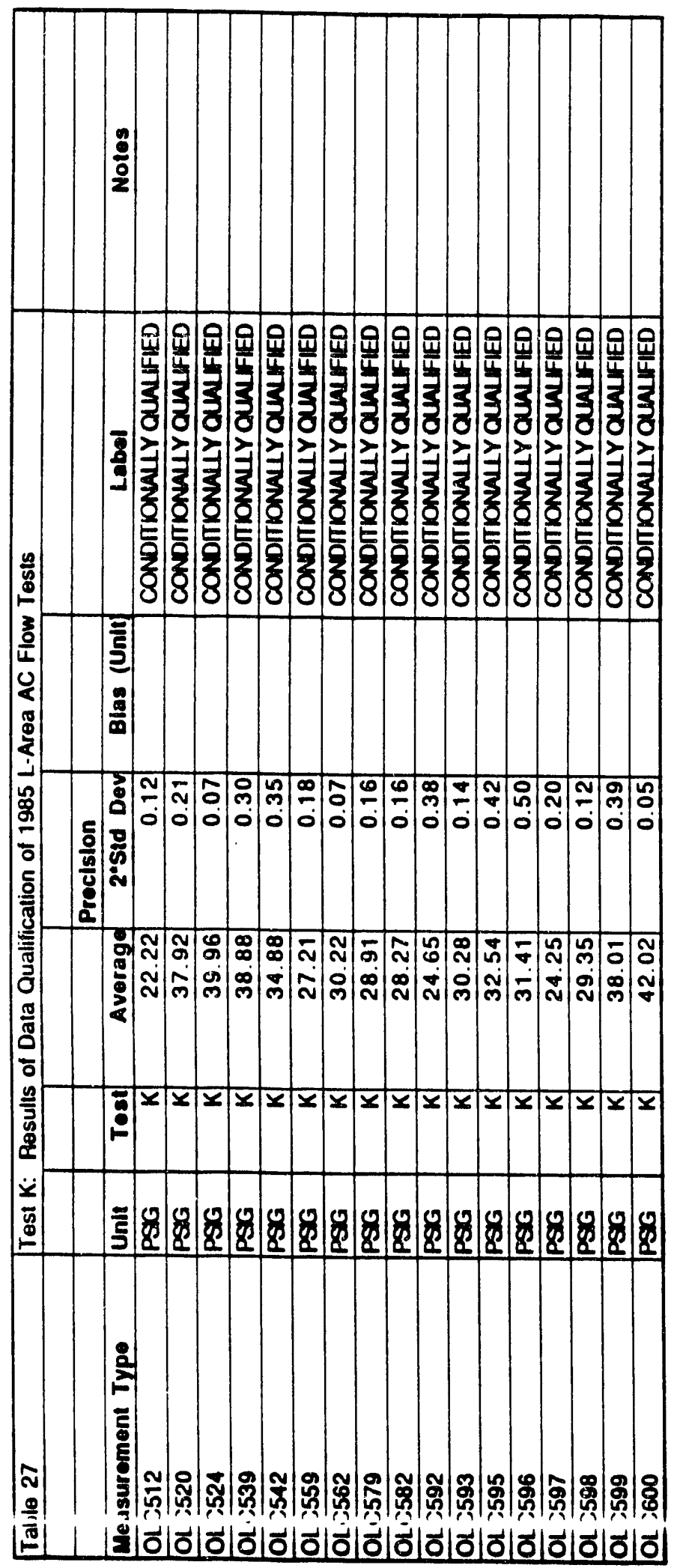



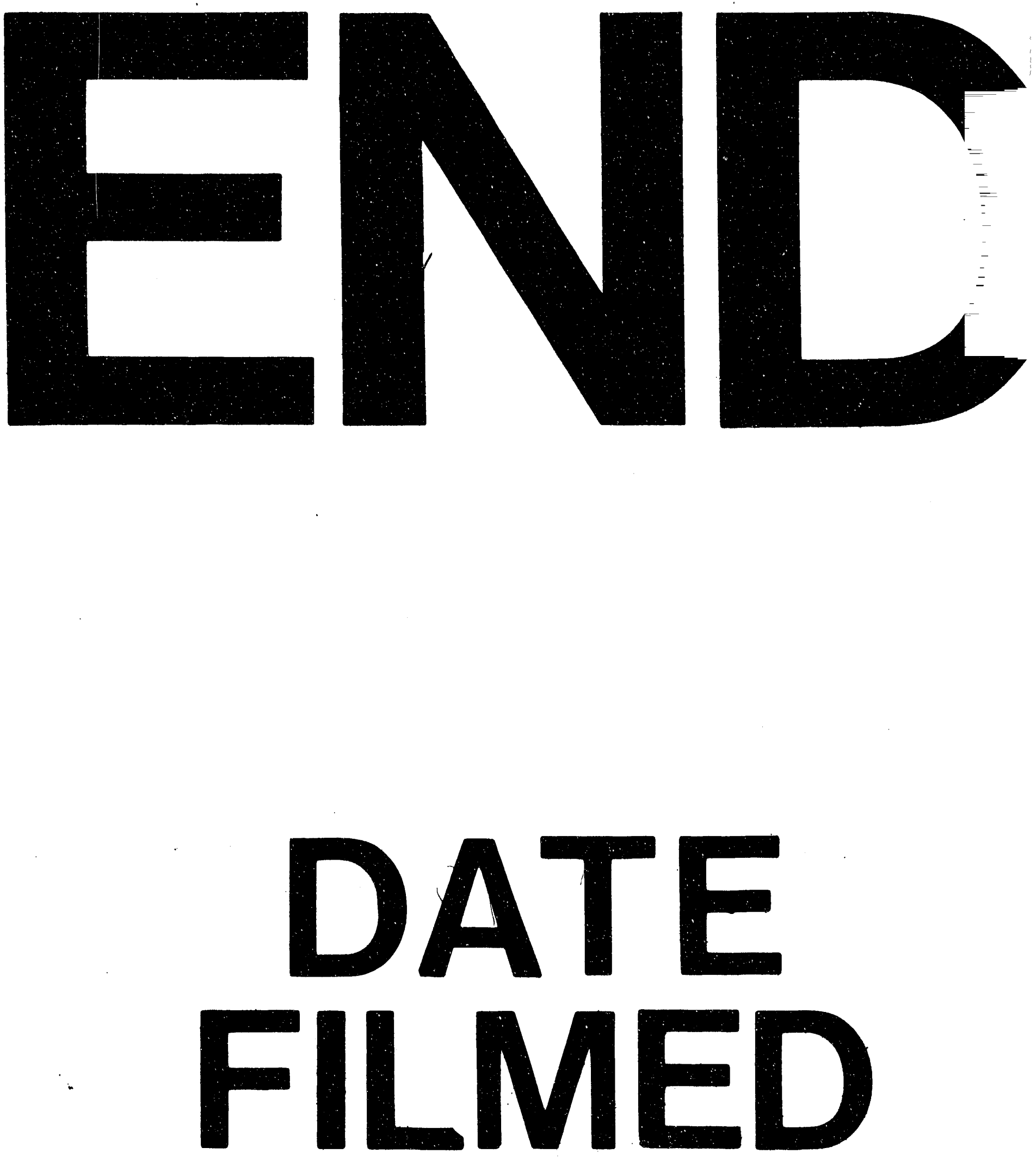

I

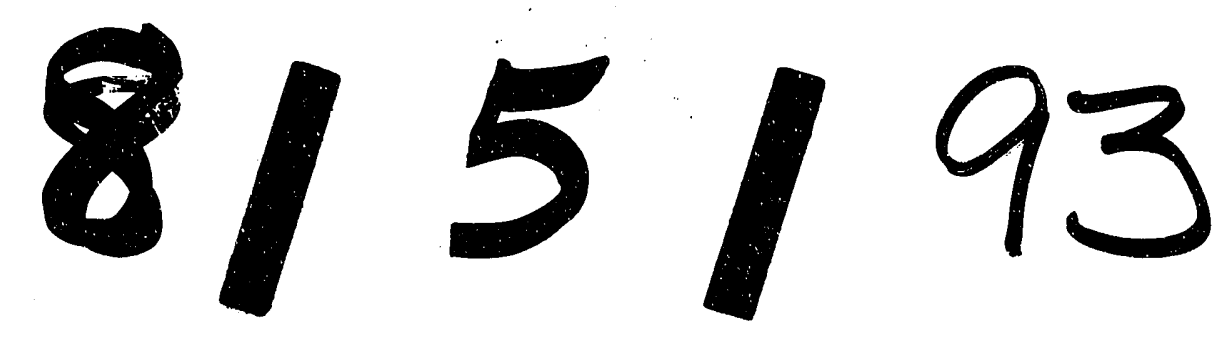


